UNIVERSIDADE FEDERAL DE MINAS GERAIS

Programa de Pós-Graduação em Estudos Literários

\title{
ENTRE HISTÓRIA E FICÇÃO: \\ Heródoto um Mensageiro Trágico
}

Mirelle Bernardi

Belo Horizonte

2010 
Mirelle Bernardi

\section{ENTRE HISTÓRIA E FICÇÃO: HERÓDOTO UM MENSAGEIRO TRÂGICO}

Dissertação apresentada ao Programa de PósGraduação em Estudos Literários da Universidade Federal de Minas Gerais, como requisito parcial à obtenção do título de Mestre em Estudos Clássicos

Área de concentração: Literatura, História e Memória Cultural

Orientador: Prof ${ }^{\mathrm{o}}$. Jacyntho Lins Brandão

Universidade Federal de Minas Gerais

\section{Belo Horizonte}

2010 


\section{Universidade Federal de Minas Gerais}

\section{Faculdade de Letras}

Programa de Pós-Graduação em Letras: Estudos Literários

Dissertação intitulada Entre história e ficção: Heródoto um mensageiro trágico, de autoria da mestranda Mirelle Bernardi, para aprovação da banca examinadora constituída pelos seguintes professores:

Prof. Dr. Jacyntho Lins Brandão - UFMG

Profa. Dra. Teresa Virgínia Ribeiro Barbosa - UFMG

Prof. Dr. Pedro Ipiranga Júnior - UFPR 
Aos meus filhos, Ana e Lucca, elos de meu infinito. 


\section{AGRADECIMENTOS}

São inúmeras as pessoas a quem devo este trabalho. Gostaria de começar pela Professora Tereza Virgínia Ribeiro Barbosa. Sem dúvida alguma, foi minha primeira

referência. É um exemplo que quero seguir. Não há nada que se possa dizer em agradecimento à sua paciência e atenção. Devo muito a ela por ter me incentivado e não ter me deixado desistir antes mesmo de começar.

Professor Jacyntho Lins Brandão. Dizer a que se agradece é algo absolutamente desnecessário. Basta dizer que foi ele meu orientador. Seu nome já diz tudo: referência, conhecimento, paciência, exigência, pesquisa, esforço e, o principal, resultados. Certamente, é ele também um exemplo que quero seguir. Sinto-me profundamente honrada em ter tido a oportunidade de ter sido sua orientanda e tenho grandes esperanças de ter correspondido a tal oportunidade.

Agradecer a minha família é a mais difícil de todas as partes. Como agradecer a meu marido por ter sido, além de marido, dono-de-casa e "pãe" (algo além de pai, mas que ainda não é uma mãe). Foi quem esteve na minha ausência e muito comigo na presença. Meus filhos: Ana, cachinhos de ouro que iluminam minha vida e Lucca, meu sorriso que resolveu chegar sem pedir licença e encher este trabalho de mais emoção. E ainda minha mãe e meu pai por serem os grandes financiadores de meus sonhos. E meus irmãos... Presenças da vida inteira.

Amigos! Que medo de não lembrar todos: meus companheiros de grego clássico, principalmente "Tio Ernani Sauro" e "Dona Lúcia Saran", amigos irreparáveis; meu adorado professor de grego clássico, Gustavo Araújo Freitas, grande responsável por ter eu conseguido ingressar no mestrado, ensinando-me de maneira incrível; Manuela Ribeiro Barbosa, não sei o que teria sido todo o percurso sem seu entusiasmo, ouvidos pacientes e disponibilidade imensa de me ajudar; Maria Clara, dona de grande coragem para me fazer apreender o grego de Eurípides, Longino, Homero e Safo em quatro horas às vésperas de uma prova; meus colegas do curso: Bruna, Poddis e Luíza, companheiros das angústias e conquistas. Não posso deixar de lembrar da minha prima pelo coração, Giuliana Oliveira, por ter tão generosa e destemidamente se oferecido e encarado minha "tropinha" para que eu pudesse concluir a dissertação. E, por fim, mas não menos importante, devo agradecer à grande paciência e atenção das funcionárias do Pós-Lit, Letícia Magalhães e Hanna Campos, quando eu me arrastava com uma enorme barriga de gravidez para solucionar e entregar documentos sem fim de uma bolsa de estudos. 
Por falar nela, a bolsa de estudos, ainda que sejam enormes as críticas sobre as burocracias, lentidão, quantidade disponibilizada e valores, agradeço por ter tido minha bolsa CAPES de mestrado. É necessário que lembremos estar em um país onde muitos não chegam perto de receberem tais valores por desempenharem suas profissões e ofícios e que somos nós imensos "sortudos" por estarmos recebendo para fazer aquilo que mais amamos: o estudo e a realização de nossos desejos acadêmicos. Por isso, não posso deixar de agradecer à Coordenação de Aperfeiçoamento de Pessoal de Nível Superior pela disponibilização de bolsas de estudos aos estudantes. 
"Considera-se também como um exemplo dos mais sublimes o de Heródoto".

LONGINO, Do Sublime 


\section{RESUMO}

Sem querer negar a Heródoto o estatuto de pioneiro em um gênero novo - a História buscamos aproximá-lo, tanto no que é relativo ao estilo, quanto ao que é relativo ao conteúdo, ao mensageiro trágico. Nosso historiador possui uma relação estreita com a produção teatral de seu tempo, partilhando de profundas afinidades com as filosofias de vida veiculadas pelos trágicos do século V. A partir das Histórias, então, e de suas marcas de historicidade e de ficção, esta dissertação visa demonstrar como é possível uma comparação entre o historiador e a personagem da tragédia. O Heródoto mensageiro nos dá em seus relatos a expressão de suas emoções e opiniões, bem como na das personagens que apresenta. As histórias narradas, a partir da autoridade daquele que conta o que ele próprio viu e mais ninguém, levam ao conhecimento do povo grego as informações sobre aquilo que estava além de seu alcance. No momento da narração, estas mesmas histórias eram transcriadas por Heródoto, tal qual pelo mensageiro nas peças teatrais da tragédia grega, ganhando representações pessoais que visavam convencer e seduzir, ainda que pelo acréscimo de yeu=dov aos fatos históricos recontados. Nesse contexto, houve acontecimentos narrados e outros esquecidos que permaneciam no campo do possível, a partir do uso das incontáveis possibilidades de se repassar um discurso verossímil, pois, na verdade, a autenticidade do narrado só se concretizava como tal quando o público passava a percebê-lo como exato ou coeso nas histórias que transmitia. A intenção de Heródoto não era descrever os acontecimentos tal qual ocorridos, mas fazer conhecer e não esquecer os feitos dos bárbaros e dos gregos de seu tempo e, para isso, narrava de maneira estimulante sob o ponto de vista da forma narrativa de uma novidade informativa. Como resultado de nossa pesquisa, concluímos que o historiador de Halicarnasso compartilhava dos sentimentos, angústias e tendências dos homens da época em que viveu, produzindo uma obra que o singularizaria ao longo dos tempos, com um cunho de atualidade para cada época que o analisaria, graças à percepção e transmissão de histórias narradas sob uma forma muito original e caracterizada por uma quebra de barreira entre a ficção e a realidade.

Palavras-chave: Heródoto, Histórias, historicidade, ficção, mensageiro trágico 


\begin{abstract}
It is not denying to Herodotus the position of pioneer in a brand new genre - the History - we seek to approach him to a tragic messenger, thinking both in the style and in the content. Our historian has yet a sharp relation with the theatrical production of his time and shares deep affinities with the life philosophies passed by the tragic authors of the V century. So, this dissertation goals to demonstrate how is possible the comparison between the historian and the character of the Greek tragedy from The Histories and from their marks of historicity and fiction. The Herodotus messenger gives us in his reports the expression of his emotions and opinions as well he presents in his characters. Telling from who has the authority to say because he saw whatever nobody could see, the narrated histories bring to the knowledge of the Helens the informations about what was beyond their view. In the moment of the report, these same histories were transcreated by Herodotus in the same way they were transcreated by the messenger in the theatrical plays of the Greek tragedy, earning personal representations which had as aim to convince and to seduce even if they had to put the yeu $=\mathrm{dov}$ in the middle of the historical facts reported. In this context, some events were told and others were forgotten, but both of them remained in the field of the possible because of the use of the uncountable possibilities to retell a verisimilar speech. This can happen because, in reality, the authenticity of the thing narrated just could be materialized as authentic when the public could notice the histories as an exact and meaningful report. The Herodotus' intention was not describe the events as well they had occurred, but he intend to tell what should be known and what could not be forgotten from the things that Barbarous and Greeks had made in his time and to achieve this purpose he narrated in a exciting way if we look by the point of view of the narrative form of a informative novelty. Thus, as result of our research we conclude that the Halicarnassus historian shared feelings, anguishes and tendencies of the men of his life time. He made a masterpiece which singularizes him throughout the times and which had a mark of actuality to each age in which it was analyzed. It was due to the perception and transmission of narrated histories under a very original way and because The Histories are characterized by a broke of barrier between fiction and reality.
\end{abstract}

Key-words: Herodotus, The Histories, historicity, fiction, tragic messenger 


\section{SUMÁRIO}

1 INTRODUÇÃO

2 HERÓDOTO ENTRE HISTORIADOR E FICCIONISTA 18

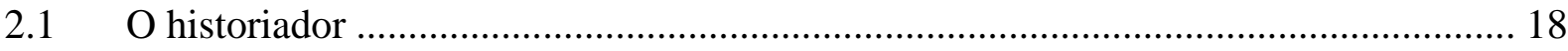

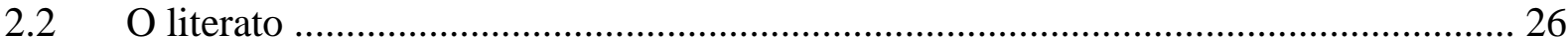

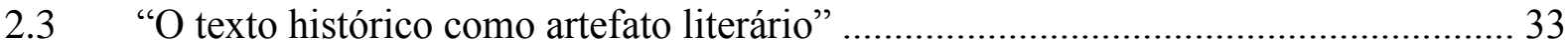

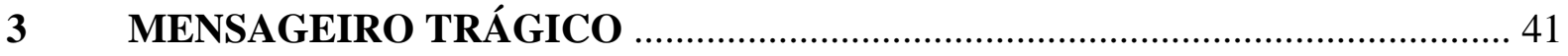

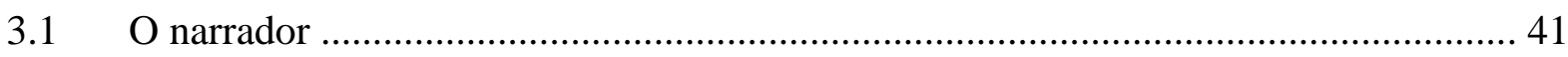

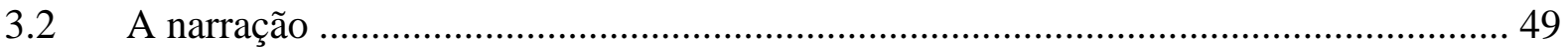

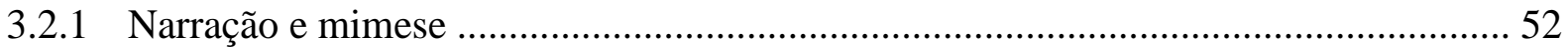

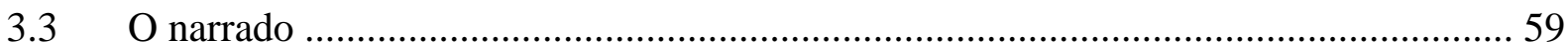

4 HISTÓRIAS TRAGICAMENTE NARRADAS E DRAMATIZADAS .............. 67

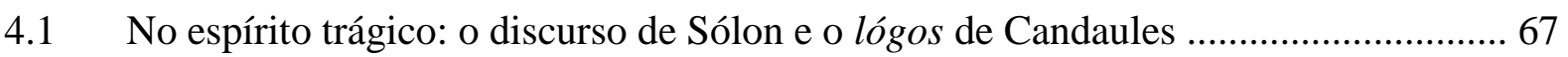

4.2 Comportamento não-verbal: o sorriso sardônico no lógos de Cleómenes .................... 84

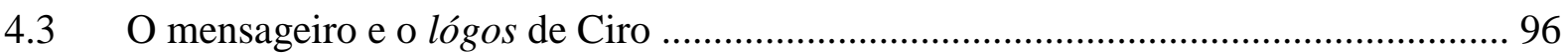

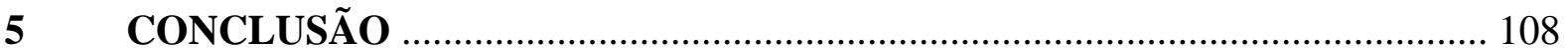

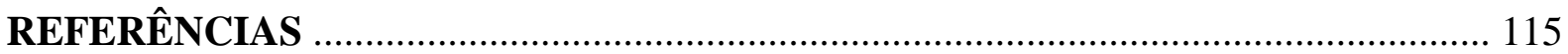




\section{INTRODUÇÃO}

O presente trabalho tem como tema, a partir da obra Histórias de Heródoto, a discussão das marcas de historicidade e ficção, de maravilhoso e de espetacular com o intuito de, principiando por essas marcas, estabelecer uma relação entre o narrador - Heródoto - das Histórias e um mensageiro trágico. Não nos limitamos, contudo, a discutir sobre a veracidade do discurso herodotiano ou sobre ser nosso autor historiador ou ficcionista. O que apresentamos nesta dissertação é um autor/mensageiro que entra em cena.

Nesse sentido, focalizamos um entre-lugar da história oral. Isto é, o "método escolhido" por Heródoto - recolhimento e comparação de testemunhos orais e visuais em busca de uma possível verdade - serviu de suporte para nossa demonstração. O autor em questão diz buscar a verdade ${ }^{1}$ dos fatos. Acreditamos que, de fato, ele era um curioso sobre a forma pelas quais se davam os acontecimentos e pretendia construir uma narrativa que expressasse uma verdade - dos eventos, do particular - a partir da comparação entre diversos testemunhos. Ora, tendo o fato ocorrido ou não daquela maneira, seria obrigação do narrador convencer e dar "autenticação" ao caso narrado. Buscamos, então, refletir acerca das múltiplas formas de preservação, transmissão e recepção da tradição escrita e oral antiga e das técnicas de teatralização do texto escrito, as quais, é bom recordar, tiveram, na Grécia Antiga, seu auge no período de vida de Heródoto.

Nossa abordagem tem início pela obra de Hayden White intitulada Trópicos do Discurso, mais precisamente o capítulo $O$ Texto Histórico como Artefato Literário. A obra A Invenção do Romance de Jacyntho Lins Brandão, ou, mais especificamente o que a ela traz acerca da sistematização teórica do "estatuto do narrador" também é de fundamental importância para a construção de nossa argumentação. Este autor destaca, a partir do vocabulário aristotélico para definir o mensageiro na tragédia, três pontos que poderiam ser aplicados a Heródoto: “(...) a anterioridade do acontecido com relação ao narrado , contra a simultaneidade de acontecimento e de representação do drama; (...) a mediação do próprio discurso narrativo para representar fatos e objetos fora do alcance de visão dos recebedores; (...) a total dependência dos recebedores (...) à atividade do ángelos (...) o que decorre, (...), do

\footnotetext{
${ }^{1}$ A verdade aqui é referente ao significado da própria palavra em grego, isto é, alétheia. Esta é formada por um prefixo de negação, $a$, e uma raiz, léthe, que significa esquecimento. Com isso queremos dizer que a verdade buscada por Heródoto provinha de um movimento de deixar de esquecer, ou seja, a verdade enquanto algo que uma vez esquecido se fez "des"- "esquecer" pelo questionamento e estímulo da memória.
} 
distanciamento temporal e espacial entre o acontecimento e narração" (BRANDÃO, 2005b, p.46-47).

Partindo do princípio de que toda sociedade tem uma memória própria que não é exatamente sua história (narrada) ou mesmo um arquivo (de fontes), mas uma "memória viva e corporal", uma identidade coletiva formada de milhares de histórias e gestos, buscamos demonstrar que através de uma possível movimentação entre oral e escrito, entre historicidade e literalidade, entre verossímil e fantástico, as Histórias trazem ao nosso conhecimento um mesclado de "representações". Heródoto aproxima-se não somente de um historiador ou de um literato, mas de um "mensageiro trágico", um "narrador de acontecimentos", principalmente no momento em que o mesmo está, a partir daquela movimentação, rompendo a fronteira entre a ficção e a realidade e atuando com vistas a (re)apresentar os fatos que aconteceram fora do alcance de visão do seu auditório.

Situamos Heródoto, então, em um diferente patamar, o de um mensageiro, isto é, aquele que viria, depois de ouvir e ver, a transcrever, transcriar $^{2}$ e narrar, pelo texto escrito e, talvez, por uma provável narração oral - a qual incluísse gestos, tom de voz, pausas facilmente detectáveis no grego pelas partículas, interjeições, exclamações etc. - a "memória viva e corporal" pertencente ao "mundo" das tragédias atenienses. Tentamos, pois, comprovar que há uma técnica de criar veracidade do fato nas Histórias, através de efeitos discursivos já experimentados no teatro.

Portanto, o objetivo deste trabalho é realizar uma comparação entre o discurso do mensageiro nas tragédias e as técnicas de narrativa de Heródoto, procurando resgatar os possíveis sentidos existentes na fronteira do narrador escritor e do narrador mensageiro. Nesse sentido, nosso trabalho é estruturado em três capítulos, quais sejam: 1) Heródoto entre historiador e ficcionista; 2) Mensageiro trágico; e, 3) Seleção de histórias fantásticas.

Em "Heródoto entre Historiador e Ficcionista" damos início à discussão da figura de Heródoto a partir da etimologia da própria palavra grega i9storía. \#Istwr significaria ver na qualidade de testemunha, ou seja, ele seria aquele que sabe por causa do fato de ver, porque viu. Heródoto, ainda que não tivesse visto o fato ele mesmo, teria e buscava acesso ao acontecimento através da narrativa de outrem, para, em seguida, reproduzir o fato recebido pela palavra para seu auditório. Dessa forma, ele apresenta-se como aquele que presenciou,

\footnotetext{
${ }^{2}$ Entenderemos como transcriação, neste trabalho, o processo através do qual a história, no momento em que é (re)contada, seja na forma oral, seja na forma escrita, traz em si um pouco de seu narrador/contador, que adapta o texto ao contexto dos eventos, buscando uma interação com o público, que poderá ser um espectador ou um leitor.
} 
pois também é um espectador/leitor/ouvinte, e/ou aquele que interagiu com quem presenciou o acontecimento.

De fato, o ser humano e sua relação com/no tempo - a história - não são conhecidos somente pelo racional; não se fala do outro permanecendo diante dele, ou de seu vestígio, e descrevendo-o. É necessária uma compreensão empática que vá além da mera observação. Com esse embasamento, afirmamos, então, que este tipo de convivência com o outro amplia as perspectivas do entendimento do que seja um "narrador", isto é, um "vivenciador" da história de outro narrador. Compartilhar não só aumenta a experiência do vivido, como faz com que ela se torne mais real. Trata-se de uma proposta discursiva de escutar o outro, ouvindo-o em sua própria linguagem. Entendemos, então, que, nesse trabalho, a função narrativa tem uma abordagem múltipla, não só de fazer ver, mas, também, de compartilhar a opinião sobre o fato que foi visto por meio de palavras. Vejamos o recurso em uma comparação entre Heródoto e Eurípides.

Heródoto:

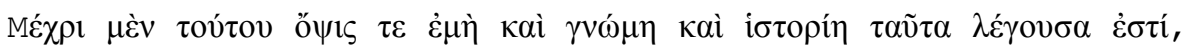

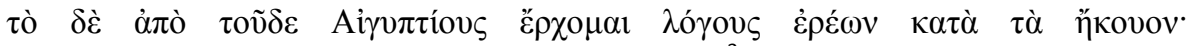

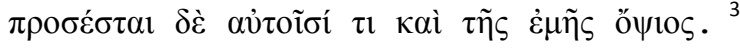

Disse até aqui o que vi e o que consegui saber por mim mesmo em minhas pesquisas. Falarei agora do país, baseado no que me disseram os Egípcios, acrescentando à minha narrativa o que tive ocasião de observar com meus próprios olhos. (HERÓDOTO, II, 99)

Eurípides:

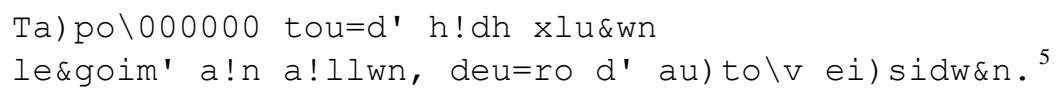

O que se passou a seguir, vou relatá-lo segundo testemunhos alheios. Até aqui contei o que eu mesmo vi. (Heraclidas, v. 847-848)

Expressões como "Disse até aqui o que vi e o que consegui saber por mim mesmo", "Falarei agora baseado no que me disseram acrescentando à minha narrativa o que tive ocasião de observar com meus próprios olhos", "O que se passou a seguir, vou relatá-lo segundo

\footnotetext{
${ }^{3}$ Todos os trechos em grego deste trabalho, referentes às Histórias, foram retirados de http://www.sacredtexts.com/cla/hh/index.htm

${ }^{4}$ Foram utilizadas aqui duas traduções das Histórias para o português. Para os Livros I, III, IV, V, VI e VIII utilizamos a tradução das Edições 70 e para os Livros II, VII e IX a tradução de J. Brito Broca da Prestígio Editorial.

5 Todos os trechos em grego das tragédias foram retirados de http://www.perseus.tufts.edu/hopper/collection?collection=Perseus:collection:Greco-Roman\&redirect=true
} 
testemunhos alheios" e "Até aqui contei o que eu mesmo vi" parecem aproximar o universo da tragédia e o de Heródoto na postura do mensageiro, numa possível isenção e num pacto com a plateia ouvinte ou leitora.

Portanto, o alcance da maior veracidade estaria na contraposição, no diálogo e na comparação entre os diferentes discursos. Nosso autor funciona como um intérprete, reconhecendo limites, escutando, participando e abrindo-se, em relação ao seu objeto, à novidade e à diferença e o seu trabalho implica em fazer uma série de operações tais quais a memorização, a reflexão, a observação, o rememoramento e a "reconstrução". "Então, em Heródoto, literatura e história são uma e a mesma, pela forma do trabalho e por ser a compreensão de ambas mutuamente dependente" (IMMERWAHR, 1966, p. 15. Tradução nossa). ${ }^{6}$ As diversas versões de um mesmo fato são, aqui, irrelevantes, quando literatura e arte misturam-se à história no intuito de gerar prazer no momento da "narração" das Histórias, isto é, no momento da recepção e da acolhida do narrador. Parece-nos ser exatamente isso o almejado por Heródoto, que, ao traçar sua "representação do outro", não diz fazer opção ou julgamento sobre as versões de um mesmo ocorrido e, estabelecendo um diálogo entre os contrários - pois ambos são parte do vivido e do dito -, faz surgir sua "verdade vivida", buscando, assim, compreender e/ou tornar compreensível o mundo humano.

No segundo capítulo, ao abordarmos a figura do mensageiro buscamos mostrar que a obra escrita, de história ou ficção, intermedia a aproximação entre seu autor e seu leitor. Entretanto, por mais direta e objetiva que se pretenda a escrita - no caso da história - ou fiel aos sentidos conferidos pelas palavras aos atores e às ações - no caso da ficção -, ela sempre se fará simbólica na representação valorada das realidades a ela subjacentes. A leitura e seu entendimento, por sua vez, também não conseguem se dar livres da apreciação pessoal e dos significados cifrados próprios de cada leitor/ouvinte/espectador. Na verdade, a obra estabelece um diálogo entre o leitor, o autor e toda a carga de referências, de todos os tipos, que ambos possuem. Quanto às Histórias, Heródoto e seu "público", essa relação é dada na maneira como nosso historiador-ficcionista estetiza os fatos passados colhidos, realizando a construção, através de suas palavras, das imagens (visuais e sonoras) que por ele foram experimentadas - acerca das épocas tratadas e da época vivida - e a "invenção" dessas mesmas imagens na apropriação que cada indivíduo fará delas, considerando suas realizações psicológicas e intelectuais - também acerca das épocas tratadas e da época vivida.

\footnotetext{
6 "Thus, in Herodotus, literature and history are one and the same, for the form of the work and its insights are mutually dependent".
} 
Entendemos, então, que faz parte de Heródoto uma paixão pelo saber, pelo ver e pelo "narrar" e, considerando que ele escrevia em um período no qual as obras eram levadas ao conhecimento dos demais através de grandes narrativas públicas ${ }^{7}$, seu trabalho implicava também em cuidado com a linguagem, uma vez que seu discurso seria submetido aos outros e deveria se sustentar - quer pela "veracidade", quer pela fantasia - a todo custo. Ou seja, havia Histórias, mas o mais importante seria a maneira como elas seriam contadas. E, assim, reconhecemos que, no momento no qual a escrita voltava à sua forma aberta de articulação oral do tema, assumindo um aspecto, inclusive, de comunicação direta, os aspectos históricos do texto mesclavam-se ainda mais a uma estrutura mítica, fazendo com que os elementos de ficção se tornassem sempre mais evidentes dentro do enredo criado pelo autor para sua narrativa. ${ }^{8}$ De fato, de acordo com as palavras de Immerwahr:

O conhecimento histórico em Heródoto move-se em três níveis: eventos, tradição sobre os eventos e o trabalho histórico que interpreta estas tradições. Ao longo das Histórias, Heródoto mantém a ficção de que sua obra é um relato oral, mesmo onde nós sabemos ou supomos estar ela baseada em fontes escritas. Ele podia fazer assim porque a maior parte de suas fontes era, de fato, oral, e também porque ele mesmo parece ter feito apresentações sobre assuntos históricos. (1966, p. 6-7. Tradução nossa $)^{9}$

Por fim, no terceiro capítulo, tratamos de realizar uma seleção de histórias fantásticas da obra herodotiana. A partir dessa seleção, mostraremos como as imagens construídas pelas palavras, na mente dos leitores/espectadores/ouvintes, falam por si mesmas, e, por isso, muitas vezes o texto vem repleto de detalhes que, não sendo nem cruciais, nem tendo significado simbólico, levam-nos a constatar a presença de um excesso de adjetivos que, na verdade, são usados para caracterizar fatos narrados. As Histórias nos apresentam inúmeras passagens nas quais podemos observar a riqueza na representação dos "pormenores", como, por exemplo, quando se fala acerca das cerimônias de sacrifício no Egito:

\footnotetext{
${ }^{7}$ Afirma-se que, pronta sua história, Heródoto quis levá-la ao conhecimento de todos os gregos juntos e não pouco a pouco em separado. Para tanto, teria escolhido os Jogos Olímpicos. Luciano de Samósata inclui-se entre os que divulgam tal versão. Cf. LUCIANO. In: Obras. V. III. p. 440-444.

8 “(...) Herodotus stands alone, midway between the two cultures, oral and written: his book was definitely composed and written for readers, but its substance and its approach are largely oral" (FLORY, 1987, p. 16).

9 "Historical knowledge in Herodotus moves on three levels: events, tradition about the events, and the historical work which interprets these traditions. Throughout the Histories, Herodotus maintains the fiction that his work is an oral account, even where we know or surmise it to be based on written sources. He could do so because the larger part of his sources was in fact oral, and also because he himself seems to have lectured on historical subjects."
} 


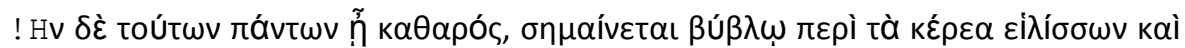

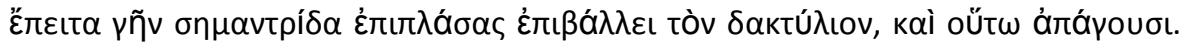

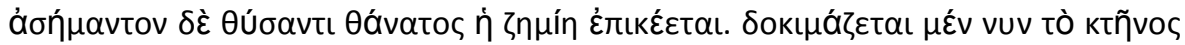

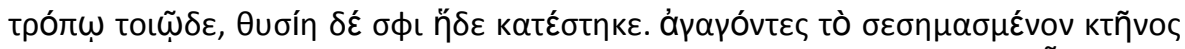

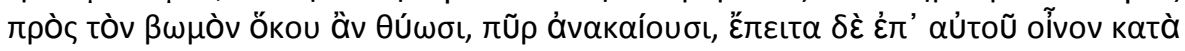

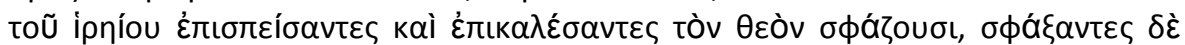

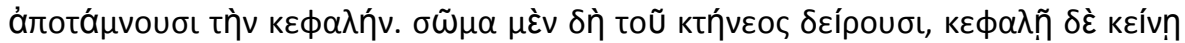

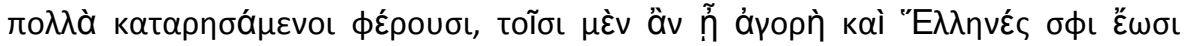

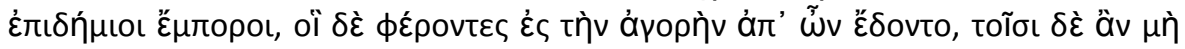

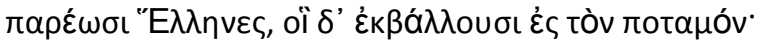

Se o boi é tido como puro sob todos os aspectos, o sacerdote marca-o com uma corda de casca de papiro, ligando-lhe os chifres. Em seguida, aplica-lhe a terra sigilária, sobre a qual imprime sua chancela, pois é proibido, sob pena de morte, sacrificar um boi que não possua essa marca. Eis as cerimônias que se observam no sacrifício: Conduz-se o animal assim marcado ao altar onde deve ser imolado; acende-se o fogo, espalha-se vinho sobre o altar, perto da vítima, que é, então, estrangulada, depois de se haver invocado o deus. Corta-se-lhe, em seguida, a cabeça, profere-se toda sorte de imprecações sobre ela, após o que é levada ao mercado e vendida a qualquer negociante grego, ou, em caso contrário, atirado ao rio. (HERÓDOTO, II, 38-39)

Causar prazer com o texto, de acordo com a pesquisa que realizamos, é um ponto fundamental em Heródoto. A ambientação em cenários, descritos ricamente e com teatralidade, trazem a fantasia por uma variedade de versões acerca de um mesmo fato ocorrido. Muitas vezes o leitor é induzido a ter uma sensação mais vívida da cena narrada pela própria exposição dos objetos e pessoas em paisagens e cenários interiores. Também era necessário ao autor criar para e na mente de sua "audiência" ${ }^{10}$ as formas físicas e psicológicas de suas personagens, chamando a atenção para suas ações, que, por sua vez, deixariam de ser anônimas, ganhando um toque mais realístico. ${ }^{11}$

Heródoto expressava e traduzia as ideias que habitavam sua própria mente pela densa descrição de detalhes, sendo um homem de letras, um poeta e um literato, ele era, também, neste momento, alguém que dava incumbência às suas palavras de despertar emoções, comover, intrigar e persuadir. Portanto, acreditamos que o que ele buscava era convencer ou, mais que isso, seduzir seu leitor, ouvinte e/ou, quem sabe mesmo, espectador para a realidade que conheceu pelo testemunho, quer de terceiros, quer seu mesmo.

\footnotetext{
${ }^{10}$ Utilizamos o termo "audiência" procurando recordar que o leitor/ouvinte estava bastante acostumado aos textos trágicos e suas convenções, entre as quais incluímos o mensageiro como personagem que carrega notícias de fatos indiscutivelmente verídicos.

${ }^{11}$ Para exemplificação mais específica, como na passagem sobre Giges, Candaules e sua esposa, cf. FLORY, 1987, p. 34-38.
} 
"A inteligência dos fatos requer a ordem dos tempos e a descrição dos lugares. Pede também, já que em fatos importantes e dignos de memória se espera que haja primeiro deliberações, depois execução e em seguida resultados, que sobre as deliberações seja indicada aquela que o autor aprova; sobre os efeitos, que se declare não só o que se fez ou se disse, mas também qual o modo; e, quando se fala do resultado, que se devolvam todas as causas que se devem ao acaso, à sabedoria ou à temeridade". 


\section{HERÓDOTO ENTRE HISTORIADOR E FICCIONISTA}

\subsection{O historiador}

No decorrer de nosso trabalho confessamos que, primeiramente, cometeremos aquilo que Nicole Loraux diz ser "o pesadelo do historiador, o pecado capital contra o método, do qual basta apenas o nome para constituir uma acusação infamante, a acusação - em suma - de não ser um historiador, já que se maneja o tempo e os tempos de maneira errônea" (2002, p. 57), isto é, o anacronismo. Tomando como referência Loraux, afirmamos que em um trabalho sobre a Antigüidade, o melhor ponto de partida é o próprio lugar do qual falamos, ou seja, o presente que se afigura, por ora, como a forma mais eficiente de penetrar e compreender uma personalidade e seu mundo, tão distintos do nosso. Ao passarmos ao processo de "descobrir, traduzir e interagir" com Heródoto dentro de todo um universo de diferenças sociais, psicológicas e morais detectando similitudes entre o papel do mensageiro no teatro e a atuação de Heródoto, teremos que aceitar, então, que será "preciso usar de anacronismo para ir na direção da Grécia antiga", com a condição de assumirmos "o risco de colocar ao objeto grego questões que já não sejam gregas; (...) submeter o material antigo a interrogações que os antigos não se fizeram ou pelo menos não formularam ou, melhor, não recortaram como tais" (LORAUX, 2002, p. 61). Contudo, o que desenvolveremos, aqui, é o que Loraux chama de "uma prática controlada do anacronismo". Isso quer dizer que buscamos tratar tanto presente quanto passado com uma reserva de questões, sem querer neles encontrar prefigurações um do outro. Maior mobilidade e cautela se fazem necessárias às distinções uma vez que reconhecemos que nenhuma identificação com sentido é duradouramente possível. $^{12}$

Heródoto teria nascido em 484 a.C. e vivido até cerca de 420 a.C. Ele conheceu o exílio, que fez dele um estrangeiro, até sua instalação em Túrio, na Itália. As datas de seu nascimento e morte coincidem com o falecimento de Dario e ascensão de Xerxes no império dos persas. Sua vida decorreu, então, em meio aos extraordinários acontecimentos que colocaram frente a frente gregos e bárbaros. Os feitos das Guerras Médicas sem dúvida

\footnotetext{
${ }^{12}$ Diz Hayden White: "Uma das marcas do bom historiador profissional é a firmeza com que ele lembra a seus leitores a natureza puramente provisória das suas caracterizações dos acontecimentos, dos agentes e das atividades encontrados no registro histórico sempre incompleto" (1994, p. 98).
} 
influenciaram o espírito do grego de Halicarnasso de maneira decisiva para que sua curiosidade, interesse e sentimentos pelos seus antepassados do continente aflorassem de forma a levá-lo em busca da apuração dos fatos em contato direto com os povos do conflito.

Nosso autor, tomado pela paixão de saber, ver e contar viajou por todo o mundo conhecido, buscando constituir suas Histórias com amor pela verdade e pela beleza, tão comum aos gregos de seu tempo: "o historiador verdadeiro será aquele que não economiza nem seu tempo, nem sua pena, nem seu dinheiro para percorrer os espaços e ver com seus próprios olhos" (HARTOG, 2001, p. 36). ${ }^{13}$ Sua obra abarca grande extensão de assuntos, correspondendo à história dos povos conhecidos até então. Contudo, apesar da multiplicidade que apresenta, ao deixar claro que seu assunto será as Guerras Médicas, Heródoto atribui ao seu trabalho uma incontestável unidade, dando-lhe o tom de uma obra histórica, narrando eventos que realmente aconteceram, que deixaram traços físicos e que permanecem na memória das gerações vindouras e demonstrando, também, interesse na causa histórica.

Podemos dar, então, início à discussão da figura de Heródoto a partir da etimologia da própria palavra grega i9storía que, formada a partir do verbo i9storei n, é derivada de i3stwr. Etimologicamente, então, ela nos remete a iodei n (ver) e a (w)oi [da (saber):

\begin{abstract}
Investigação em todos os sentidos da palavra. $\mathrm{O}$ termo designa mais um estado de espírito (a ação de quem historê̂) e um tipo de iniciativa (um método), que um domínio particular em que ela se exerça especificamente. (...) Heródoto fará dela a palavra-chave de todo o seu empreendimento (...). Em suma, se a história até hoje não cessou de tomar emprestado as noções que emprega e propõe para cada época, como um instrumento destinado a produzir um acréscimo de inteligibilidade, Heródoto inaugurou essa prática, começando por tomar emprestado e pôr à disposição o próprio nome do que se tornará a história. (HARTOG, 2001, p. 50)
\end{abstract}

3Istwr significa, pois, ver na qualidade de testemunha, ou seja, ele seria aquele que sabe por causa do fato de ver, porque viu. O "método proposto" por nosso autor tinha, então, como primeiro passo para o conhecimento a ação de ver, melhor dizendo, o fato deveria ser conhecido através da arguição daqueles que estiveram presentes a ele. O que nos interessa é pesquisar a palavra que faz ver: ${ }^{14}$

\footnotetext{
${ }^{13}$ Nesta parte de nosso trabalho, tomaremos as teorias de François Hartog como fio condutor e/ou pressuposto teórico de nossa análise.

14 "É proverbial, na Grécia, admitir que o olho pode mais que o ouvido e, por consequência, que o objeto de visão é mais poderoso que a palavra" (BRANDÃO, 2005b, p. 17). A importância do ver para a cultura grega pode ser atestada em Aristóteles que nas primeiras linhas da Metafísica afirma: “(...) nós preferimos a vista (alguns podem dizer) a todo o resto. A causa disto é que ela, mais que todos os sentidos, nos faz saber e trazer à luz muitas diferenças entre as coisas” (980a).
} 
Daí em diante, para "ver" é preciso arriscar-se (ir ver) e aprender a ver (recolher testemunhos, reunir as diferentes versões, relatá-las, classificá-las em função do que se sabe por outras fontes e também em função do grau de verossimilhança). (HARTOG, 2001, p.51)

Heródoto é o autor das Histórias ou poderíamos dizer das "Investigações". A obra se inicia da seguinte forma:

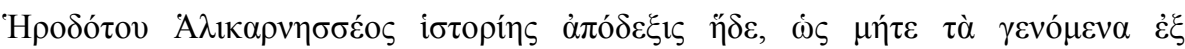

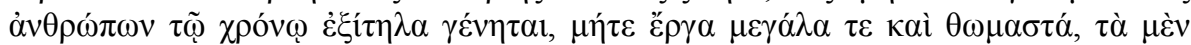

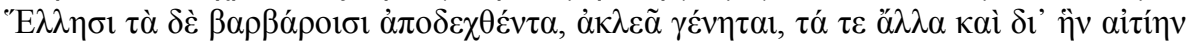
$\dot{\varepsilon} \pi \mathrm{o} \dot{\varepsilon} \mu \eta \sigma \alpha \nu \dot{\alpha} \lambda \lambda \eta \dot{\lambda} \mathrm{ol \sigma l}$.

Heródoto de Halinarcasso apresenta aqui sua historíe (investigação), para impedir que o que fizeram os homens, com o tempo, se apague da memória e para que grandes e maravilhosas obras, produzidas tanto pelos bárbaros, quanto pelos gregos, não cessem de ser renomadas; em particular, aquilo que foi a causa de eles entrarem em guerra uns contra os outros. (HARTOG, 1999, p.17)
}

A título de exemplificação encetamos uma análise deste prólogo das Histórias como demonstração. Podemos verificar uma relevância em relação à $3^{\mathrm{a}}$ pessoa que fala de forma a focalizar o "ator/autor" da sentença. Seu nome no genitivo é a primeira palavra proferida,

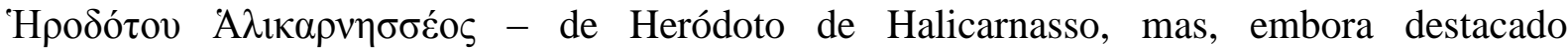
solenemente, o núcleo da expressão aparece numa segunda posição sintática. Este é a palavra

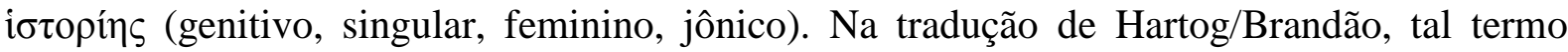
cumpre a função de objeto direto. Numa tradução mais agarrada às funções dos termos

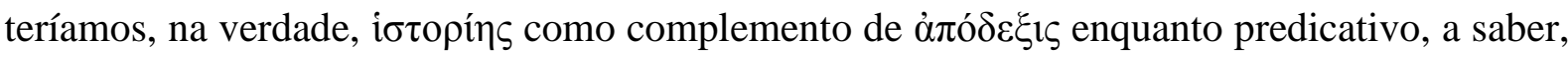
a parte mais importante da frase nominal. Queremos dizer que, então, a tradução "Esta é uma

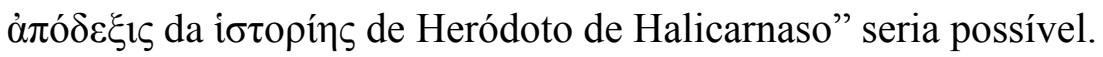

A palavra $\alpha \dot{\alpha} \delta \varepsilon \varepsilon \xi 1 \varsigma$, por sua vez, é importante não somente na frase, mas, sobretudo, em nosso trabalho. Ela significa, segundo Lidell-Scott, "mostrar, fazer conhecer, exibir". Para Heródoto, no contexto que ora analisamos, e ainda de acordo com Lidell-Scott, ela assume o sentido de "publicar, tornar público". Nossa opção será a de tomar o termo em seu sentido literal, o qual também é habilmente permitido entender, dentre outros sentidos, pela opção de Hartog/Brandão em traduzir o substantivo ả $\pi$ ó $\delta \varepsilon \xi 1 \varsigma$ pelo verbo "apresentar".

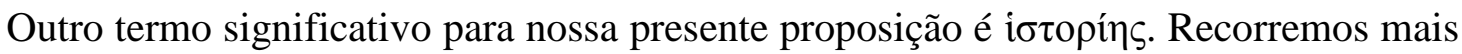
uma vez a Lidell-Scott para quem o termo significaria "investigação, narrativa obtida a partir de informação", para dizermos que, já em seu início, o texto teria um caráter espetacular que poderia ser preenchido com palavras e visões ou mesmo palavras feitas para se ver. $\mathrm{O}$ que

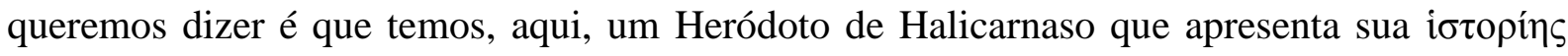


(investigação, narrativa obtida a partir de informação), isto é, um autor que teria como uma de suas intenções declaradas o intuito de apresentar sua pesquisa dos feitos e das maravilhas

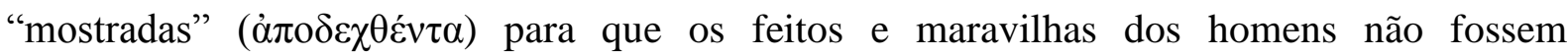
esquecidos, nem ficassem sem glória.

Com efeito, "história" é a palavra mais adequada para definirmos essa atitude intelectual de espírito investigativo. Percebemos que o Heródoto i 3 stwr lutava contra o esquecimento que ameaçava o que havia se passado, sendo organizador de uma inovação: narrativa de pesquisas expressa em prosa e em próprio nome ${ }^{15}$, substituindo as Musas do poeta $^{16}$ pela investigação, passando-se de uma verdade enunciada para uma verdade demonstrada:

(...) Desde suas primeiríssimas palavras Heródoto pretende marcar, reivindicar a narrativa que inicia pela inscrição de um nome próprio: o seu. Ele é o autor de seu lógos (ou de seus lógoi) - como ele designa sua obra - e é desse lógos, da forma como o concebeu, escreveu e compôs, que tira sua autoridade. (...) Se os gregos inventaram alguma coisa, é menos a história que o historiador enquanto o sujeito que escreve. (HARTOG, 2001, p. 17)

O método da investigação herodotiana apoiava-se, primeiramente, no olho, isto é, o fato de ver/testemunhar em pessoa. Em seguida, vinha o ouvido que recebia, oralmente, as informações daqueles que sabiam ou que se considerava que sabiam: Heródoto escrevia de acordo com o que ouviu ${ }^{17}$, com o que se dizia ${ }^{18}$ e com o que diziam os gregos ${ }^{19}$. Portanto, ele era um narrador sujeito das enunciações. A forma de saber estava relacionada ao ver e ao ouvir, pois a narrativa era dependente dos testemunhos:

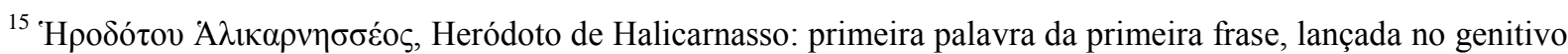
que, diferentemente do eu épico, disposto no dativo, "assinava", como artista, a obra. Heródoto dá uma assinatura inaugural de alguém que vem apresentar sua pesquisa em público e em próprio nome e, assim, põe em relação um autor e um texto, delineando o lugar do narrador no interior da narrativa, o que, extrapolando o texto, pode apontar as intenções do processo de escrita/criação da obra.

${ }^{16}$ Embora Heródoto não seja um aedo que a Musa inspira, ele retoma e transforma a tarefa do poeta arcaico: contar os acontecimentos passados, conservar a memória, resgatar o passado, lutar contra o esquecimento. Porém, se a relação com o passado dava-se por meio do aedo que imortalizava os heróis cantando seu kle/ov, Heródoto fala do passado de uma nova forma: o aedo precisa da inspiração das musas para vencer o tempo e o espaço e proferir seu canto; Heródoto usava o conhecimento humano para narrar suas Histórias.

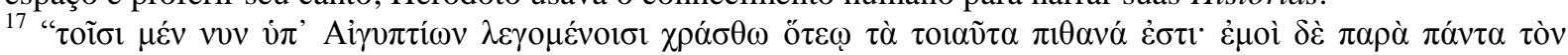

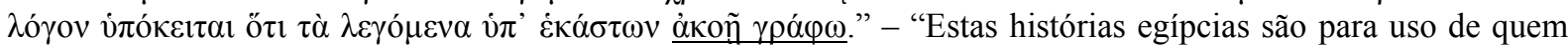
mais acreditar em tais contos: para mim, é a minha regra através desta história que eu escreva o que quer que seja dito para mim tal qual eu ouvi" (HERÓDOTO, II, 123. Grifo nosso).

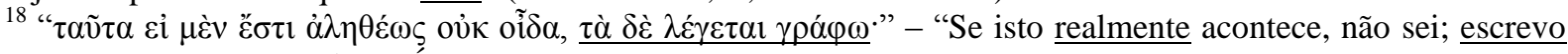
apenas o que se conta" (HERÓDOTO, IV, 195. Grifo nosso).

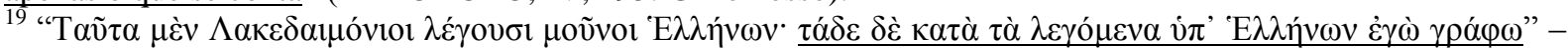
"Os Lacedemônios são os únicos, de entre os Gregos, a darem esta versão. O que vem a seguir, escrevo-o de acordo com o que afirmam os Gregos em geral" (HERÓDOTO, VI, 53. Grifo nosso).
} 
A primeira forma de história (...), organiza-se em torno de um "eu vi" - e esse "eu vi", do ponto de vista da enunciação, dá crédito a um "eu digo", na medida em que digo o que vi. O invisível (para vocês) eu torno "visível" através do meu discurso. (HARTOG, 1999, p. 278)

Como viajante e/ou observador, Heródoto inseria-se, no contexto grego como i3stwr, antes de tudo por testemunhar. Ele foi o primeiro a voltar a i9storía para o passado próximo e buscar uma descrição etnográfica dos lugares de forma a tornar mais vasta sua descrição. A preocupação era a de, pelas informações pesquisadas através de suas testemunhas, proporcionar dados que enumerassem e medissem, tratando dos espaços habitados até onde o mundo era conhecido, e propor aos gregos uma verdadeira representação do mundo, em que se organizavam os lugares e os homens, os bárbaros e os gregos: “Antes de ser historiador, Heródoto foi geógrafo e etnógrafo. Há, pois, o viajante e o historiador das Guerras Médicas. De viajante, ele tornou-se historiador, e sua obra testemunha essas duas etapas, como também a passagem de uma à outra" (HARTOG, 1999, p. 36).

São as testemunhas e os testemunhos que Heródoto convoca que lhe servem como prova. O conhecimento era baseado, portanto, em depoimentos de testemunhas. Por terem presenciado o fato - com toda sua carga emotiva - e por poderem narrá-lo - também com toda sua carga emotiva -, elas funcionavam, aqui, como uma "espécie de musa mediadora". A testemunha podia dar sua verdade sob a forma de revelação "emocional" e Heródoto aparece como aquele que, através de entrevistas, podia fazer - a partir da carga expressa pela testemunha/personagem original - algo ser visto. Assim, i9storía toma a perspectiva de algo relativo, pela vivência espetacular de um acontecimento narrado. É, todavia, um procedimento que extrai o conhecimento não só do que foi visto, mas, também, da linguagem, que, ouvida, consegue fazer ver: "Descrever é ver e fazer ver: é dizer o que você viu, tudo o que viu e nada mais do que viu. Mas se você não pode dizer senão o que viu, não pode ver senão o que é dito: você, leitor ou ouvinte, mas você também, testemunha que conta algo" (HARTOG, 1999, p. 261).

O i3stwr torna-se um "mestre da palavra que constrói visões" e que se qualifica como tal por uma série de discursos/narrativas, isto é, por situações persuasivas de enunciação (HARTOG, 1999). E, por esse caminho, é, enquanto testemunha ocular ou por buscar conhecer junto aos que o são, um "mensageiro", que, através de sua palavra, faria o receptor "conhecer" o fato e, ao "conhecê-lo", persuadir-se de sua veracidade: "o aspecto fabuloso, maravilhoso, concede à narrativa um caráter persuasivo, visto que o interesse do narrador é contar tudo que viu e ouviu, mesmo que seja estranho" (RODRIGUES, 2000, p. 82). Temos, 
aqui, então, dois movimentos: histórias que passam da oralidade - testemunhos - ao escrito Histórias - para voltarem à oralidade - contação de Histórias. Em outros termos: de testemunhas para Heródoto; e de Heródoto para seu público.

Ressaltamos ainda que, nas Histórias, segundo Hartog, há uma tentativa de organização do "espaço grego do saber", bem como de uma representação de um passado próximo através do exercício de interpretação e de tradução do outro:

Fazendo o inventário dos povos longínquos e dos confins da terra, ele inventa a oikouméne: ordena o mundo humano. O espaço da narrativa apresenta-se como representação do mundo, sendo o rapsodo aquele que eídea semaínein, que desenha as figuras, que faz ver, que revela - em suma, que sabe. (HARTOG, 1999, p. 354)

O outro não é apresentado em um saber definitivo, mas, sim, em termos de um saber compartilhado, manifestando a técnica de fazer o ouvinte crer que ele também constrói esse saber (HARTOG, 1999). É necessário enfatizar que a relação de nosso historiador com seu público foi pautada na diversidade de culturas abordadas e na demarcação de diferenças entre elas. Entendemos, então, que, nesse trabalho, a função narrativa tem uma abordagem múltipla, não só de fazer ver, mas, também, de compartilhar a opinião sobre o fato que foi visto por meio de palavras. Afinal, Heródoto realizou uma investigação e visava fazer crer que aquilo que dizia era verdade.

Nesse contexto, a memória apresenta-se como algo mais do que o simples fato de lembrar. Numa relação de significante e significado, interessaria ao nosso historiador/mensageiro/narrador o encontro de relações entre os fatos que são narrados lembrados, e dos que não são - os esquecidos, ${ }^{20}$ tanto quanto, posteriormente, uma interação eficaz com seu "espectador". Na mistura do textual com o corporal e do objetivo com o interativo-subjetivo, o lembrado e o esquecido acabariam por se completar na transmissão do real, pois narrar é reiterar o vivido e o compartilhado. Acabamos por verificar que, em Heródoto, “(...) é característica de seu estilo esconder o caráter formal de seu trabalho por trás da ficção do relato informal” (IMMERWAHR, 1966, p.15. Tradução nossa). ${ }^{21}$

\footnotetext{
20 “.(...) Nossas explicaç̃̃es das estruturas e dos processos históricos são determinadas mais pelo que deixamos de fora das nossas representações do que pelo que nela incluímos. Pois é nessa brutal capacidade de excluir certos fatos no interesse de constituir outros em componentes de estórias compreensíveis que o historiador exibe seu tato e sua compreensão. A 'coerência total' de qualquer 'série' determinada de fatos históricos é a coerência da história, mas essa coerência só é alcançada mediante uma adaptação do 'fatos' às exigências da forma da estória" (WHITE, 1994, p. 106).

${ }^{21}{ }_{1}(\ldots)$ it is characteristic of his style that he likes to hide the formal character of his work behind the fiction of informal reporting."
} 
Heródoto relata as diferentes tradições que conseguiu colher viajando por muitas terras e descobrindo culturas diversas, com valores postos sempre em comparação com mundo grego do qual fazia parte. Ele era bem informado, o que lhe garantia a condição de realizar, em sua narrativa, um julgamento, com opinião particular sobre os relatos recolhidos em sua investigação. $\mathrm{Na}$ verdade, suas próprias experiências entravam em confronto com os dados daquilo que lhe narravam e as variáveis das narrações acerca de um mesmo fato eram trabalhadas como que por um juiz que, ouvindo as testemunhas, aplica critérios de verdade de forma a estabelecer sua própria versão crítica. Para tanto, não era suficiente conhecer os fatos, mas compreender tudo que se relacionava com eles. Ao historiador, essa contraposição de testemunhos permite investigar as influências, adaptações e trocas entre as culturas, sobretudo a helênica e as não-helênicas ou quase helênicas (HARTOG, 1999), compreendendo alteridades e igualdades, pelo choque com os valores que elas não partilham e que, por isso, raramente se encontram ou muito menos se conhecem intimamente: "interpretar uma cultura se faz a partir da análise dos códigos estabelecidos, considerando a importância atribuída a eles pela sociedade" (MORELO, 2000, p. 66).

Por seu "método", o autor de Halicarnasso formula uma interpretação ou teoria e logo descobre fatos excepcionais que são, para a modernidade, difíceis de explicar satisfatoriamente. As personagens descritas na obra acabam por não se ajustar total e facilmente aos tipos gregos conhecidos e, por isso, os fatos, as próprias pessoas ou os registros acabavam por se mostrar exasperadamente esquivos, necessitando, então, que Heródoto buscasse o que os historiadores atuais chamam de novos vieses de interpretação da evidência. Na verdade, a possibilidade de utilização do discurso das testemunhas com a finalidade de construir um panorama de diferentes personagens e suas "histórias" é intrínseca à própria abordagem oral. Esta trata de vidas individuais que se afiguram bastante interessantes e os gestos cotidianos ou rituais ganham importância de acordo com a significação que têm perante as comunidades - helênica e bárbara, no caso de Heródoto criando códigos comportamentais e de uma visão bastante particular do mundo. Ora, é possível compreender, então, o porquê de Heródoto balizar o mundo a partir dos helenos, quase helenos ou não helenos, uma vez que os próprios gregos - ou os próprios bárbaros criaram códigos de conduta que diferiam entre si e demarcavam singularidades no entendimento de seus mundos.

A fala, por ser uma habilidade menos exigente e restritiva que a escrita, permite que a história seja registrada e apresentada por um caleidoscópio de palavras que faz o passado surgir de maneira extraordinariamente imediata. As palavras podem, de fato, pelos narradores 
- Heródoto ou suas testemunhas - de maneira idiossincrática e, por isso mesmo, mais expressiva, insuflar vida nas Histórias, lançando vida para dentro da História e alargando seu campo de ação. A evidência oral consegue algo mais penetrante e mais fundamental para a narrativa, transformando os fatos em sujeitos, tornando as personagens da obra mais ricas, vivas, comoventes e verdadeiras. A expressão oral é uma rica tentativa dos indivíduos de fazer durar os significados pelos quais cada membro da sociedade interpreta suas experiências e organiza sua conduta. E o conjunto de símbolos das comunidades acaba por formular valores, construindo "uma imagem de realidade, onde os acontecimentos têm, necessariamente, um significado e acontecem por causa desse significado" (MORELO, 2000, p. 67).

A obra herodotiana apresenta, então, um interesse pela diversidade cultural tendo em vistas os relatos que possibilitam que os argumentos se completem ou se contradigam. Podese afirmar que foi importante para Heródoto construir suas histórias utilizando todas as fontes disponíveis porque lhe interessava preservar do esquecimento a identidade das diferentes culturas. E, era ainda de fundamental importância para esse historiador respeitar o espaço de manifestações das divergências dentro de uma mesma cultura, porque sua identidade se manifestava por aquilo que possuía de comum e de diferente (MORELO, 2000). As Histórias passam a ser uma composição de diálogos entre o narrador e seu espectador e a História torna-se um processo de colaboração mais amplo a partir do momento em que pessoas e locais de toda a espécie ganham um papel central na narrativa. Segundo Hartog, o texto dá a impressão de ecoar diálogos e discussões com o auditório (1999). Enquanto historiador, Heródoto não pretende uma única história, mas a produção de verdades. ${ }^{22} \mathrm{E}$, pela descoberta dos fatos através das testemunhas, a percepção do passado deixa de ser meramente conhecida para ser mais presente e pessoalmente vivida:

O texto de Heródoto é um discurso do particular que reconhece, na diversidade cultural, a expressão (em uma condição de igualdade e liberdade) das diferenças. Sua narrativa é um constante diálogo em que as diferentes opiniões sobre um assunto são expostas ao seu destinatário, o ouvinte-leitor, seja pelas palavras do historiador ou pela voz de suas personagens. Por sua vez, o destinatário, ao recebêlas, é convidado também a manifestar sua opinião. (MORELO, 2000, p. 119-120)

\footnotetext{
${ }^{22}$ No caso de nosso autor, uma possível definição para a0lh/qeia seria a de mostrar pelas palavras, pelo discurso, o desconhecido. Pensamos, inclusive, ser possível que tal questão não tenha sido considerada pelo próprio autor, uma vez que as experiências literárias anteriores já tinham habituado o público grego a discernir as verdades escondidas em falsidades, o que constatamos, por exemplo, em Hesíodo e Homero (a propósito de Ulisses), respectivamente: "Sabemos dizer muitas falsidades que se assemelham a verdades" (Teogonia, v. 2728) e "Ele fingia, dizendo falsidades semelhantes a verdades" (Odisseia, XIX, 203).
} 
O Heródoto historiador é aquele que nos apresenta uma investigação realizada com postura crítica diante das fontes que lhe eram disponíveis - isto é, oral e escrita - buscando aproximar-se de "uma verdade". Suas pesquisas mostravam ao seu espectador, quer leitor, quer ouvinte, informações precisas contidas na riqueza de detalhes de sua narrativa. Ele não se julgava mais capaz que seus leitores/ouvintes de estabelecer um veredito acerca das informações que lhe eram passadas. Com efeito, "a verdade" não era objetivo da atividade de nosso historiador, que se apoiava sempre em discursos particulares e, portanto, opiniões sobre a verdade. O objetivo, como por ele mesmo exposto, era de preservar do obscurecimento $(\mathrm{a} 0 \mathrm{kle} / \mathrm{a})$, pela forma escrita, os feitos tanto dos helenos, quanto dos bárbaros.

\subsection{O literato}

O homem é capaz de conhecer porque também é capaz de colocar-se no lugar do outro, reconhecendo-se ou estranhando-se nele. As ações humanas se dão ao conhecimento através das suas mais variadas formas de expressão e manifestação morais e subjetivas. Com esse embasamento, afirmamos, então, que este tipo de convivência com o outro amplia as perspectivas do entendimento do que seja um "narrador", isto é, um "vivenciador" da história de outro narrador. Heródoto é ainda mais que isso, ele é um colecionador de retalhos da vida humana, é um contador de existências.

A descrição por escrito do fato fez com que o historiador fosse denominado de $\bigcirc 9$ suggrafeu\&v, isto é, "aquele que compõe por escrito", dando início a uma tradição de escrita da história na qual são feitas certas escolhas, produzidos "esquecimentos", deslocamentos e reformulações. Isso é bem exemplificado no pequeno trecho das Histórias que se segue: “A terra da Lídia, em comparação com outros países, não possui, muitas maravilhas que mereçam ser descritas, se exceptuarmos as partículas de ouro que o Túmulo arrasta" (HERÓDOTO, I, 93. Grifo nosso). ${ }^{23}$ Porém, se, por um lado, o que Heródoto faz é i9stori/a, suggrafeu\&v, por outro, é a palavra que designa literato ${ }^{24}$. O verbo

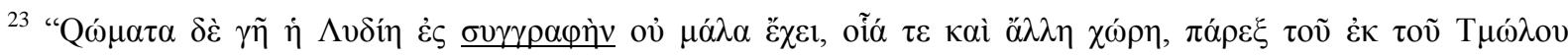

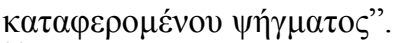

${ }^{24}$ Na Poética do Hipocentauro, Jacyntho Lins Brandão, ao discutir sobre o suggrafeuv, o historiador e a suggrafh no contexto da obra luciânica, afirma: “(...) syngrapheús pode ser traduzido por historiador, mas não tem sentido restrito, como teria historiagráphos, podendo designar o escritor (...). O historiador pratica a syngraphé; mas syngráphei historías. Assim, creio que as características do singrapheús ideal não devem ser entendidas como aplicáveis apenas ao historiador, mas se refiram ao escritor ou prosador (...)” (2001, p. 42-43).
} 
suggra/fein significa tomar nota, registrar por escrito. E, neste sentido, a dimensão da escrita ganha o primeiro plano, principalmente porque o autor adotou a escrita como forma final de sua narrativa ${ }^{25}$.

Heródoto escolheu contar as histórias que eram mais ricas tematicamente e que considerava mais reveladoras sobre a vida humana. Porém, em suas Histórias, ele parece, aos leitores, ter conhecimentos que não lhe seriam acessíveis e, muitas vezes, chega a contradizer o que as evidências físicas provam ser real e verdadeiro em nome de criar uma narrativa mais atrativa para aquele mesmo leitor. Outros escritores possivelmente escolheriam e escolheram ignorar contradições entre verdade e ficção, mas Heródoto engenhosamente chama atenção para elas. De fato, parece-nos que tais contradições através da obra de que ora tratamos constituem uma chave que unifica o todo do conjunto. Vejamos como.

A narrativa herodotiana se dá de duas formas: a primeira caracteriza-se por sua intervenção direta, em que sua opinião é expressa, e, na outra, dá-se voz às personagens de suas Histórias. Essas duas formas narrativas possuem em comum a relação estabelecida entre o historiador e seu público. Relação esta pautada pela palavra-diálogo em que o argumento é relativo à sua capacidade de persuadir. Heródoto parece fazer questão de deixar às claras, em diversas passagens do texto, que sua obra é resultado da coleta e "transcrição" de diversas falas:

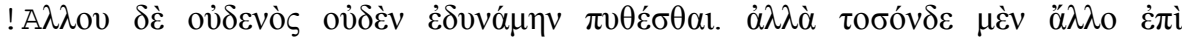

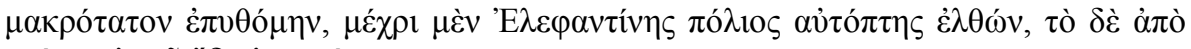

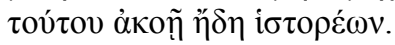

Não encontrei pessoa alguma que me pudesse adiantar mais sobre esse fato, e isso é tudo que consegui saber levando minhas pesquisas até onde foi possível. Até Elefantina vi as coisas com meus próprios olhos, de lá em diante, o que apurei foi por informações. (HERÓDOTO, II, 29)

Por esse exemplo, podemos perceber que o autor conversa com seu público e que existem "vozes" a compor o texto, inclusive as vozes que se manifestam por técnicas de

\footnotetext{
${ }^{25}$ Não ignoramos aqui que, embora a escrita tenha reaparecido no século IX ou VIII, depois de três séculos, a comunicação e a cultural oral tenham permanecido preponderantes, mesmo porque, se uma cultura faz alguma espécie de uso da escrita, isso não significa o abandono de sua tradição oral. Consideramos, ainda, que no período clássico em questão, houve a manutenção da tradição oral e seu compartilhamento com a escrita no processo de preservação e distribuição do conhecimento. Inclusive, para a tragédia, ponto importante em nosso trabalho, embora sua forma fosse a escrita, sua comunicação se dava na forma de representação dramática e oral para as platéias nos teatros gregos. Heródoto é, justamente, um homem entre o oral e o escrito e as Histórias é uma obra única composta sob as circunstâncias também únicas de uma sociedade grega que passava, justamente, da cultura oral para a escrita. Na verdade, nosso autor produz nove livros escritos para leitores, mas a substância deles e sua abordagem são largamente orais.
} 
narrativa trágica. Esta "pluralidade fônica" é caracterizada nas Histórias ora pela citação, ora pela paráfrase, respectivamente nos seguintes exemplos:

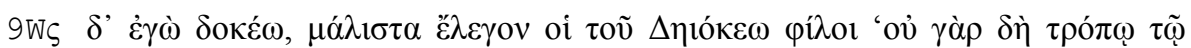

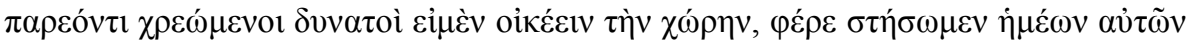

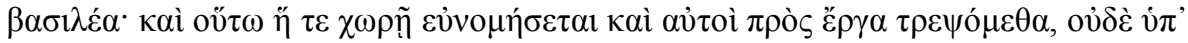

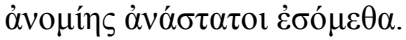

Fez-se a análise da situação (ao que suponho foram sobretudo os amigos de Déjoces a usar da palavra): "Uma vez que, nas circunstâncias actuais, nos é impossível viver nesta terra, pois bem, façamos rei um dos nossos. Assim este território será governado com acerto e nós poderemos entregar-nos ao trabalho, sem estarmos sujeitos a distúrbios" (HERÓDOTO, I, 97)

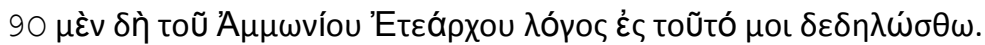

Contentei-me em reproduzir até aqui a narrativa de Etearco. (HERÓDOTO, II, 33)

De fato, o testemunho de terceiros é fonte fundamental para as mais minuciosas investigações

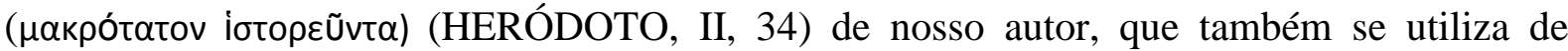
diálogos/conversas entre suas "personagens" (históricas) para trazer vida e individualidade às mesmas (FLORY, 1987).

Porém, sua escrita não é isenta das próprias impressões:

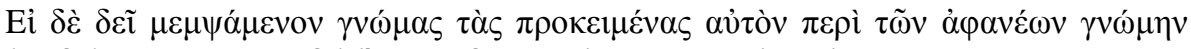

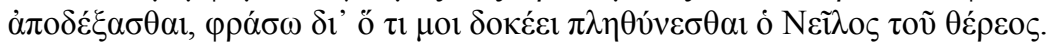

Se depois de ter refutado essas opiniões torna-se necessário que eu mesmo declare o que penso sobre a questão, direi que me parece ser a seguinte a razão da cheia do Nilo no Verão. (HERÓDOTO, II, 24)

e, em outros momentos, há mesmo o seu parecer sobreposto ao dos outros:

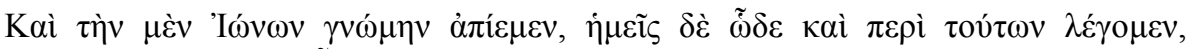

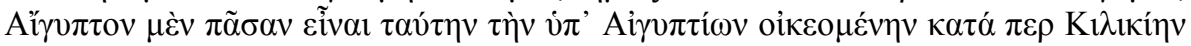

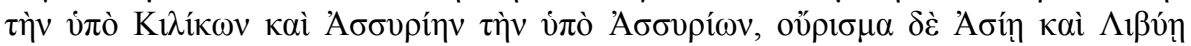

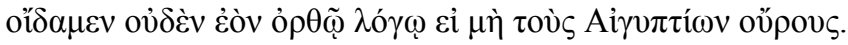

Deixemos de lado a opinião dos Iônios e falemos nós mesmos do assunto, de acordo com o que conseguimos apurar. Penso que se deve dar o nome de Egito a toda a extensão do país ocupada pelos Egípcios, da mesma maneira que chamamos a Cilícia e Assíria os países habitados pelos Cilícios e pelos Assírios. É o Egito que, a justo título, poderemos considerar como o limite da Ásia e da Líbia. (HERÓDOTO, II, 17) 
Observamos, então, que os acontecimentos históricos narrados não são isentos da percepção e da relação mútua dos sujeitos envolvidos com a obra. É nessa interlocução de dizeres, isto é, na fala do autor misturada à das outras "personagens", suas testemunhas, que verificamos que a narrativa em Heródoto - ainda que dos fatos históricos - não pode possuir aspectos de tragicidade, comicidade, fantasia, mitologia e religiosidade que a ela sejam atávicos, uma vez que o tom dos eventos seria engendrado por pontos de vista particulares que compõe as Histórias.

Por fim, temos a autoridade do autor que apresenta um outro que fala pelo discurso direto, o que, por sua vez, atesta a busca de eficácia no discurso oral e a incorporação das falas das "personagens". Nessa postura, temos "pessoalidade" na fala que, por sua vez, apresenta, intencionalmente, as circunstâncias de enunciação: quem fala e para quem fala. Uma opção assim tem evidentes vantagens, sobretudo para o discurso literário, pois ilumina não apenas a própria fala, mas, também, dá à narrativa uma espécie de sentido temporal e verdadeiro. Com efeito, são estas formas de narração que fazem com que ouvinte-leitor acredite nas diferenças mediante a utilização dos diálogos que, seja exprimindo sua opinião, seja permitindo a expressão de forma direta, dão voz à opinião de outrem e do próprio historiador.

É pressuposto, então, um recebedor determinado e um autor que se nomeia por um nome próprio. O "eu" diz tudo do ponto de vista da enunciação. O narrador é o único sujeito da enunciação e, por isso, o único que sabe e, com isso, traz veracidade ao texto. A narrativa adquire status de verossímil e o sujeito da enunciação, ou, em termos concretos, nosso historiador/literato, apresenta-se diante do público.

Heródoto buscava fazer seu leitor/ouvinte ver o que se passou. $\mathrm{O}$ apelo à experiência visual impulsionava o discurso e parece-nos que a idéia era a de por sob os olhos da audiência aquilo que o historiador intencionava que ela soubesse. O próprio texto apresentava-se, ao leitor, como narrativa que partia de um registro visual com o qual rivalizava. Era fazer o outro ver, saber e crer que o que se contava era verdade: "se crê que o que se vê é o que se conta" (HARTOG, 2001, p. 235), porque "eu vejo, eu digo; eu digo o que vejo; eu vejo o que posso dizer; eu digo o que posso ver" (HARTOG, 1999, p. 280). A história deveria ser narrada e decifrada, pois os acontecimentos desdobravam-se no que era dito e no que significavam entre o que escrevia o narrador e o que entendia o recebedor:

Com efeito, as diversas figuras são postas em movimento pelo narrador, que intervém de múltiplos modos no interior de sua própria narrativa. A leitura deve, pois, atentar para todas as marcas de enunciação que apresentam essas figuras e que, 
para o destinatário, as carregam finalmente com um peso específico da persuasão. (HARTOG, 1999, p. 228)

É uma espécie de alquimia no qual o histórico transformava-se em figurado, fazendo com que um mesmo acontecimento tomasse formas variadas de acordo com o entendimento próprio do interlocutor, pois o foco estava na própria representação, menos que no objeto representado. A verdade, então, deixa de ser tão somente a conclusão de uma investigação, ou o que, talvez, possamos chamar de verdade histórica, para assumir um papel mais rico, isto é, as verdades das narrativas passam a ser ditas e não demonstradas; elas podem provar, mas não se provarem, pois a dissimilaridade, a dissonância e as contradições são traços essenciais das Histórias. De fato, parece-nos que o próprio Heródoto reconhece, muitas vezes, a limitação histórica de suas histórias, mas, ainda assim, acredita que elas podiam revelar aspectos importantes sobre os homens reais e seus motivos.

O propósito literário da obra explica o princípio de seleção das várias versões apresentadas. Se Heródoto encontrava uma versão que continha temas e ideias que acreditava significantes e, ao mesmo tempo, acreditava que esta versão era historicamente acurada ( 09 e $0 \mathrm{w} / \mathrm{n}$ lo/gov) ou, pelo menos, não contradita pela evidência factual, ele suprimia todas as outras versões. Mas, normalmente, versões diferentes da própria história contada eram narradas, pois, sem criticismo ou reservas, elas poderiam coincidir artística e historicamente: “Há fatos que é preciso ver, observar, 'encontrar' (evidentemente através das palavras), e discursos que é preciso não reproduzir literalmente, mas antes reconstruir (em função do que mais convém ser dito), sendo o discurso histórico uma mistura dos dois" (HARTOG, 2001, p. 99). Neste caso, as versões coexistiam porque, ainda que seu conteúdo fosse contrário à evidência material, as diferenças serviam ao autor como convite indiscriminado ao leitor a acreditar naquilo que preferisse, mesmo que ele mesmo pensasse ser uma das versões a verdadeira. As perspectivas contraditórias do estilo herodotiano refletem a consciência das pessoas acerca dos problemas humanos ou situações inerentes a suas próprias culturas. Nas histórias repetidas, continuamente, nas várias versões, nenhuma versão é correta, mas todas são verdadeiras - ainda que se contradigam - porque todas elas falam para uma concepção cultural do mundo (FLORY, 1987).

O Heródoto suggrafeu\&v interpretava as histórias humanas transmitidas a ele e transmitia, de volta, aquilo que havia interpretado. Nesse processo, ficavam explícitos os momentos da construção da narrativa das Histórias passadas. O público pode, então, participar das fases de construção das histórias na medida em que nosso literato/historiador 
permite que este mesmo público adentre o meio de levantamento das informações, tomando parte no julgamento dos episódios narrados através da manutenção das diversas versões possíveis para uma mesma história. Ao mesmo tempo, o autor alcança credibilidade, atestada mais que pela autoridade de quem fala, pela sedução e pelo prazer da participação do público na avaliação de todas as fases da construção da narrativa, ou, pelo menos, por essa sensação adquirida a partir da forma como narra (RODRIGUES, 2000).

No momento em que o Heródoto i3stwr dá uma nova dimensão à compreensão do passado, focando em sua narrativa o plano das ações humanas, implicando na "necessidade de um método capaz de responder às questões do narrador por intermédio da capacidade e dos sentidos humanos" (RODRIGUES, 2000, p. 92), o Heródoto suggrafeu\&v passa a desenvolver sua narrativa de forma a buscar o convencimento de seu público, apresentando quer sua opinião, quer todas a versões existentes, ou pelo menos as que julgava mais verossímeis e, por isso, passíveis de serem creditadas:

(...) O notável ou, segundo a expressão de Heródoto, 'o que é digno de ser relatado' (áxios apegésios). Com esse mesmo instrumento, o autor recorta o tecido de todas as coisas dignas de serem ditas ou escritas, que existem tanto junto dos outros, quanto junto de nós. (HARTOG, 1999, p. 373-374)

A crença nas histórias narradas vinha, "antes de tudo, pela animação das figuras, pela atuação de procedimentos que reconhecemos que lhe pertencem, por sua manipulação cada vez que o narrador intervém na narrativa" (HARTOG, 1999, p. 273), introduzindo o leitor num universo marginal em que desfilam figuras humanas movidas por desejos, necessidades e sentimentos comuns. Isto é a mistura das posições de historiador e literato, aumentando o espaço do público nas Histórias no momento em que as personagens não só veem, como passam a serem vistas e, através de seus diálogos, passam a dar maior vazão à cena na fantasia dos recebedores da obra:

Mestre do ver, mestre do saber, mestre do crer pelo uso das figuras e procedimentos de uma retórica da alteridade, postos em movimento pelo jogo das marcas de enunciação, Heródoto nomeia, inventaria, classifica, conta, mede, dimensiona, põe em ordem, traça os limites, distribui louvor e censura, diz menos do que sabe, lembra-se. Ele sabe. Ele faz ver, faz saber, faz crer. (HARTOG, 1999, p. 367) 
Neste processo, as viagens do narrador, que se deslocava para ver o que podia ser visto, no processo de a Outoyi / $a,{ }^{26}$ funcionam como um elemento unificador da narrativa, "pela qual o que importa é que a audiência reste convencida de que o narrador, efetivamente, viajou", viu com os próprios olhos e, por isso, narra com veracidade (RODRIGUES, 2000, p. 97-98). À crítica de que falta rigor histórico à obra de Heródoto, podemos responder com a compreensão que ele não falseava deliberadamente. Apesar da falta de condições para o seu trabalho pioneiro, o historiador recolheu informações por suas viagens, por conversas com pessoas que foram contemporâneas a alguns eventos investigados e, talvez, até por conhecimento de documentos escritos. Contudo, ele tinha consciência da fragilidade de certas informações recebidas, apontando para o que podemos considerar contemporaneamente, salva as devidas condições, de uma forma de rigor histórico. As histórias de ficção narradas nas Histórias não tratam de equívocos ou de credulidade cega, mas preservam, de modo próprio, a simbologia cultural, antropológica e etnográfica dos povos e eventos que as cercam. Os eventos narrados não pretendem, muitas vezes, ser historicamente factuais, mas culturalmente exatos na descrição e contextualização de pessoas, povos, eventos, e para a compreensão da própria mensagem da obra.

A memória e o convencimento estavam diretamente ligados às técnicas de persuasão, pois "para enfrentar o esquecimento não era necessário nada mais que o poder da persuasão da palavra humana, fundada no método de investigação que se utilizava de meios humanos para conhecer e apresentar o passado dos homens" (RODRIGUES, 2000, p. 106). O convencimento, a verossimilhança da narrativa herodotiana reside, pois, no conjunto de todas as histórias que compõe as Histórias: “A própria acumulação de versões (francamente inconciliáveis ou dificilmente conciliáveis umas com as outras) não pode deixar de produzir um certo efeito no destinatário da narrativa" (HARTOG, 1999, p. 59). A dúvida e a incerteza introduzidas com a apresentação das diferentes versões acabam com a pretensão de que haja uma última palavra e a vontade do narrador de não escolher deixa lugar não só para a alteridade como para a escolha do espectador.

Apresentadas todas as etapas do método de fazer História, da seleção ao emprego das fontes, incluindo o esforço investigativo, e, também, apresentadas as versões dos episódios narrados, temos que a conclusão que cada leitor pode ter em relação ao narrado constitui-se como uma verdade própria e múltipla, mas sempre sujeita a modificação quando da

\footnotetext{
${ }^{26}$ Fundamentada nesse processo de autópsia, consideremos acerca da verdade nas Histórias que ela seja correspondente àquilo que é verdadeiro aos olhos de nosso autor/viajante. De acordo com Hartog (1999), esse processo - a autópsia - é o que faz o destinatário da narrativa crer que o que é narrado é fidedigno.
} 
apresentação, ainda mais persuasiva, de evidências das verdades humanas. De fato, estas verdades são multifacetadas e se permitem conviver sem, entretanto, negarem suas verossimilhanças aos olhos de leituras bastante individualizadas. Heródoto produz imagens na ideia de seu espectador, uma construção visual. A audiência helênica, assim, podia construir sua própria visão a partir da descrição oferecida e compreender o funcionamento por meio de suas próprias práticas.

\section{3 "O texto histórico como artefato literário" 27}

Estabelecer um diálogo íntimo da história com a teoria literária, sugerir a permanência de um casamento original entre a imaginação dos pensadores e sua forma de expressão pela escrita da história é um dos pontos fundamentais da teoria de Hayden White. Ele se permite desvendar intenções não explicitadas, inspirações estilísticas não confessadas, tomando-as como parte constitutiva do enredo que os autores nos deixaram. Acreditamos ter dado o autor uma grande contribuição para a "ciência histórica", ao teorizar de forma a mostrar que a realidade não mais deve ser pensada como uma referência objetiva, exterior ao discurso, pois que ela é constituída pela e dentro da linguagem, enfatizando-se a liberdade do sujeito, a parte refletida da ação e as construções conceituais de cada autor.

Ressaltamos ser necessário constatar que toda construção de interesses pelos discursos é ela própria socialmente determinada e limitada pelos recursos desiguais - de linguagem, conceitos, matérias, circunstâncias políticas, classe social, contexto histórico no qual o historiador vive, cultura, sua localização, perspectiva geográfica, região, raça, sexo etc. - nos quais se inserem os que a produzem. Em consequência, o objeto fundamental de uma história cujo projeto é reconhecer a maneira como os atores investem de sentido suas práticas e seus discursos parece-nos residir na tensão entre as capacidades inventivas dos indivíduos ou das comunidades e os constrangimentos, isto é, as normas e as convenções que os limitam - mais ou menos fortemente, dependendo de sua posição nas relações sociais estabelecidas entre os indivíduos - o que lhes é possível pensar, enunciar e fazer. E esse constrangimento é fundamental ainda nas determinações ignoradas que habitam cada obra e fazem que ela seja concebível, transmissível, compreensível. Por isso, cremos que uma história das obras

\footnotetext{
${ }^{27}$ Este trecho de nosso capítulo intitula-se tal qual o capítulo 3 da obra de Hayden White, Trópicos do Discurso: Ensaios Sobre a Crítica da Cultura, de maneira proposital uma vez que não só nos utilizamos amplamente do texto, como, também, acreditamos ser o título bastante sugestivo quanto ao que ora buscamos expor em nosso trabalho.
} 
letradas e das produções estéticas, sempre inscritas no campo do fato possível/verossímil que as torna pensáveis, comunicáveis e compreensíveis, é a produção de uma obra de arte como produto de uma negociação entre um criador e as instituições, práticas da sociedade e individuais, dos leitores que a receberão.

Uma das tarefas mais convencionalmente atribuídas ao historiador, ou seja, a de descobrir, descrever e explicar o que ocorreu no passado é, em White, reestruturada por uma tese que supõe a história como ciência e arte, ou que vê a representação e a construção dos próprios fatos como uma interferência indiscutível do narrador e a escrita histórica como algo vinculado ao trabalho de criação ou de expressão poética. Sob esse novo olhar, a compreensão da leitura particular e inventiva de um leitor singular está contida em uma série de determinações, sejam elas os efeitos de sentido visados pelos textos através dos próprios dispositivos de sua escrita, os cerceamentos impostos pelas formas que transmitem esses textos a seus leitores e/ou a seus ouvintes ou as competências ou convenções de leitura próprias de cada comunidade de interpretação. Os únicos critérios que permitem uma diferenciação dos discursos históricos provêm de suas propriedades formais:

\begin{abstract}
Uma abordagem semiológica do estudo de textos permite-nos deixar de lado a questão da confiabilidade do texto como testemunha de eventos ou fenômenos extrínsecos a ele, passar ao largo da questão da honestidade do texto e sua objetividade, e ver seu aspecto ideológico mais como um produto (seja de interesse próprio ou de interesse do grupo, seja de impulsos conscientes ou inconscientes) do que como um processo. (WHITE, 1987, p. 192. Tradução nossa) ${ }^{28}$
\end{abstract}

A obra de White é uma crítica radical à historiografia e à consciência dos historiadores. Seu conceito de história-narrativa põe em questão as pretensões de verdade e a objetividade do trabalho dos historiadores (WILSON, 1999, p. 111). Enquanto as narrativas históricas vêm de fatos ou eventos empiricamente válidos, precisa-se necessariamente de passos imaginativos para colocar esses fatos em uma história coerente.

Contudo, fazemos certa ressalva à afirmação de que toda história, qualquer que seja ela, é sempre uma narrativa organizada com base em figuras e fórmulas que as narrações imaginárias mobilizam, provocando a anulação de qualquer distinção possível entre ficção e história. Não cremos ser possível reduzir a História à ideia de que seja ela uma forma de escrita que não traz mais, nem menos, um conhecimento verdadeiro do real do que o faz um

\footnotetext{
28 "A semiological approach to the study of the texts permit us to moot the question of the text's reliability as witness to events or phenomena extrinsic to it, to pas over the question of the text's 'honesty', its objectivity, and to regard its ideological aspect less as a product (whether of self-interest or group interest, whether of conscious or unconscious impulses) than as a process".
} 
romance, por exemplo. Diferentemente de White, não cremos que as narrativas históricas sejam meramente manifestações de "ficções verbais cujos conteúdos são tanto inventados como descobertos e cujas formas têm mais em comum com seus equivalentes na literatura do que com os seus correspondentes nas ciências" (1994, p. 98).

O processo de produção da História requer procedimentos importantes tais como observação, seleção, pesquisa e construção de uma narrativa, os quais não podem ser considerados tais quais os processos de criação de uma obra literária. É verdade que não há garantias peremptórias de que um documento escrito, pintado, esculpido, gravado etc. seja verdadeiro ou de que a apropriação que o historiador faça deles seja a correta. Mas à História cabem operações específicas de construção e tratamento dos dados, produção de hipóteses, crítica e verificação de resultados, validação da adequação entre o discurso do conhecimento e seu objeto e elaboração de uma escrita que compactuem com os leitores no sentido de estabelecer uma relação na qual o público sabe-se recebedor de um discurso que busca um factual histórico que, se não verdadeiro, é verossímil em relação às provas documentais apresentadas pelo pesquisador. Na ficção, contudo, o pacto estabelecido é diferente e o público não se vê na posição de construir um quadro de verdade, mas, sim, de aceitar a imaginação do autor e a sua própria.

Portanto, mesmo que escreva de uma forma literária, o historiador não faz literatura. Como escreve Pierre Vidal-Naquet:

\footnotetext{
O historiador escreve, e essa escrita não é nem neutra nem transparente. Ela se molda sobre as formas literárias, até mesmo sobre as figuras de retórica. (...) Que o historiador tenha perdido sua inocência, que ele se deixe tomar como objeto, que se tome ele próprio como objeto, quem o lamentará? Resta que se o discurso histórico não se ligasse, através de quantos intermediários se queira, ao que chamaremos, na falta de nome melhor, de real, estaríamos sempre dentro do discurso, mas este discurso deixaria de ser histórico. (1988, p. 148-149)
}

Sabemos não ser possível pensar o conhecimento histórico, instalado na ordem do verdadeiro, tal qual nas categorias das ciências naturais e exatas. Seu objetivo não está ligado a qualquer espécie de conceito realizável numa pluralidade de exemplares congêneres e equivalentes, muito menos ao acontecer repetível e reiterativo. Porém, está ligado, sim, à propriedade e peculiaridade de fatos concretos, ao factual irrepetível e singular. Esta característica única e peculiar da História inclui uma forma específica, na qual o fato particular só adquire significado em virtude das conexões que vai estabelecendo dentro de um enredo histórico pretendido pelo historiador e de sua forma de narração dos eventos ao leitor. 
De fato, encontrar um caminho intermediário entre a redução da História a uma atividade literária de simples curiosidade, livre e aleatória, e sua definição enquanto forma de conhecimento que possui cientificidade em seu método é tarefa ardilosa. É Michel de Certeau quem bem formula esta tensão fundamental da história afirmando que o discurso historiográfico compreende seu outro, organizando-se como texto folheado de um discurso que compreende em si mesmo, sob a forma de citações que constituem efeitos da realidade, os materiais que o fundamentam e cuja compreensão ele pretende produzir, apresentando uma problemática de processo, capaz, ao mesmo tempo, de trazer uma linguagem referencial que atua como realidade, bem como de julgar em nome de um saber. A História seria, pois, um discurso que aciona construções, composições e figuras que são as mesmas da escrita narrativa, portanto, da ficção, mas se constitui como um discurso que, ao mesmo tempo, produz um corpo de enunciados científicos, a partir da possibilidade de estabelecer um conjunto de regras que permitem controlar operações proporcionais à produção de objetos determinados. Estas regras, por sua vez, estão ligadas, igualmente, aos procedimentos de acreditação específicos graças aos quais a história mostra e proclama seu estatuto de conhecimento verdadeiro (1982, p. 63-120). Nesse contexto:

\begin{abstract}
O historiador - que não pode ignorar e também não pode omitir o documento, que não pode inventar nem menosprezar os factos - jamais terá a liberdade do romancista para criar de acordo com o seu arbítrio, o que, naturalmente, o forçaria a mudar de ofício ou o obrigaria a complexa e insalubre vida dupla. Permitir-se-á apenas fazer os tipos de afirmação que deverá estar sempre em condições de relacionar criticamente com as palavras, as imagens e os sons que asseguram as marcas da objectividade, mas, assumindo a narrativa como técnica própria de uma espécie de destreza que é necessária à sua arte, poderá efectivamente ver reduzidos os limites formais impostos até há pouco, na oficina da história, à imaginação. Esta deixa de ser um campo letal, cercado de arames electrificados de alta voltagem, capazes de reduzirem a cinzas os que neles ousem tocar. Além disso, e como aspecto complementar mas não menos importante, o "historiador-poético", ao redefinir dinamicamente os limites da evidência e as formas da linguagem através das quais essa imaginação se articula, na sua prática disciplinar, com os dados objectivos, cria as condições para transformar, e não simplesmente para confirmar, a própria compreensão do mundo passado e presente. (BEBIANO, 2000, p. 13)
\end{abstract}

Heródoto insere-se no contexto que ora discutimos como um autor que não se enquadra facilmente num tipo de categoria. Nas Histórias, a forma narrativa mistura mitos e eventos excessivamente improváveis com uma gama de dados sociais e antropológicos e esta mistura se estabelece como pano de fundo para a descrição do tema principal, as Guerras Médicas: "nós não sabemos realmente o que esperar dele e, então, nós somos frequentemente 
encantados, pois nunca estamos certos de que captamos os efeitos que ele intencionava" (GREENE, 1961, p. 477. Tradução nossa). ${ }^{29}$

Interessa-nos atentar para a forma como o autor narra os temas que selecionou e a forma como ele e o leitor se entendem na moldura delineada por sua narrativa. Com o objetivo de comunicar ao público sobre o que lhe foi possível reunir acerca das diferenças e similitudes dos povos conhecidos e das intenções de uns e outros - intenções que ocasionam os conflitos entre gregos e persas - Heródoto escreve e descreve o maravilhoso (qaumásiov), o impossível e, também, o verossímil, pois escrever significa a possibilidade de suspender critérios valorativos da verdade.

As Histórias nos fornecem um quadro do universo mental grego pela pluralidade de assuntos de que trata, recolhidos a partir das experiências passadas de pessoa a pessoa. Heródoto realiza um engenhoso trabalho de intercâmbio de experiências e constrói em sua narrativa uma representação artística e literária dos fenômenos históricos. Nesse contexto, o maravilhoso (qaumásiov) deixa tornar-se essencial na percepção de como os gregos compreendiam o mundo. Nosso autor encontra-se livre para interpretar e transcriar as histórias como quiser e, não se pretendendo detentor da verdade dos eventos sobre os quais escreve, também dá ao seu leitor/ouvinte a possibilidade de interpretar o que ele narra, de acordo com suas convicções pessoais.

Não nos parece possível analisar as Histórias a partir da separação entre um "real factual histórico" e "narrativa ficcional". No jogo de observador/observado, que se caracteriza pelo olhar, o maravilhoso aparece como possibilidade concreta de compreensão da realidade. As maravilhas (qau=matov) não são, portanto, o absurdo ou a mentira; elas existem, no contexto do processo de criação da narrativa herodotiana, como uma relação concreta com a verdade, ainda que na ordem do metafórico que visa encantar e seduzir o leitor, afinal: "Todos esses elementos fantásticos estavam presentes no imaginário grego quando Heródoto começou a escrever e, narrando-os, não estaria ele recolhendo tudo aquilo em que os gregos acreditavam?” (MORAIS, 2004, p. 2005).

$\mathrm{Na}$ elaboração de sua obra, na busca pela compreensão do mundo conhecido e dos povos que o habitavam, Heródoto visava tornar familiar o não-familar, retirando-os do patamar do exótico e os classificando em outro domínio, isto é, o domínio da experiência codificada nos termos gregos, suficientemente adequados para que fossem úteis e nãoameaçadores, porque conhecidos. Nesse processo, nosso autor pode, então, tanto desviar o

\footnotetext{
29 "We do not really know what to expect of him, and so, though we are often charmed, we are never sure that we are getting the effects he intended".
} 
saber que compartilha daquilo que os fatos históricos eram em realidade para aquilo que gostaria que fossem tal qual pertinentes a sua narrativa, quanto utilizar-se de figuras de linguagem, como a metáfora, ${ }^{30}$ para melhor fazer-se compreender e seduzir o público para o que queria contar. ${ }^{31}$ Esse processo de narração é definido por White da seguinte maneira:

(...) Tomar forma a partir de uma percepção da diferença entre as figurações alternativas da realidade em imagens retidas na memória e formadas, talvez, a partir de reações a desejos contraditórios ou investimentos emocionais, até chegar às estruturas complexas, às vagas apreensões das formas que a realidade deveria tomar mesmo quando deixa de assumi-las (principalmente se não as assumir) em situações existencialmente vitais. (1994, p. 34)

Esperava-se, de quem invocava a memória, que se contassem histórias. ${ }^{32}$ Mas este contar deveria ser o melhor possível, na verdade, o mais convincentemente possível. Os fatos deveriam ser ordenados de modo a se transformarem em uma narrativa inteligível. E assim o fez Heródoto: as narrativas das Histórias, como estrutura simbólica, direcionam a leitura em relação às várias formas de pensar e de descrever o evento; os eventos não são imaginação em relação às coisas que indicam, mas, sim, trazem à mente as imagens das coisas que indicam tal como uma metáfora - possibilitando ao público a construção mental das cenas descritas. ${ }^{33}$

\footnotetext{
${ }^{30}$ Rui Bebiano, apoiando-se na teoria de Hayden White, assim diz sobre a utilização de metáforas no trabalho da escritura histórica: "O retorno do pensamento histórico ao modo metafórico conferiria uma grande liberdade ao historiador, desobrigando-o de quaisquer esforços que precisasse de fazer no sentido de encontrar uma direcção indiscutível e definitiva para o seu trabalho. Assim, tal como a poesia é em si mesma um meio através do qual se transcendem as formas da linguagem, também essa 'historiografia metafórica' seria o instrumento que permitiria abolir as regras convencionais de explicação histórica e de elaboração do enredo. A dissolução da noção de uma semântica da história representaria, ao mesmo tempo, o fim da quimera de uma história dotada de um sentido. O historiador libertar-se-ia, desta maneira, da obrigação de afirmar alguma coisa de 'certo' a respeito do passado, pois o relato deste seria apenas uma oportunidade para a criação presente de - são palavras do autor "engenhosas melodias" (2000, p. 4).

${ }^{31}$ Susan O. Shampiro, em artigo intitulado "Proverbial Wisdom in Herodous", analisa outro método literário de Heródoto para explicar os eventos históricos, isto é, aquilo que chama de "traditional wisdom", os provérbios. A autora argumenta que estes, representando a natureza transitória da felicidade humana, tornam-se através de todas as Histórias uma espécie de leitmotif do todo, pois não só refletem os modos contemporâneos de pensamento, como, também, têm uma função explanatória, sendo frequentemente mencionados como forma de influenciar ou de argumentar sobre um ponto de vista particular. Heródoto se utilizaria, então, desta "sabedoria tradicional" para enfatizar as causas dos acontecimentos, clareando visões opostas sobre assuntos importantes.

${ }^{32} \mathrm{Em}$ 1935, R. G. Collingwood declarou, em um escrito apenas postumamente publicado, que a construção intelectual da história poderia ser vista como forma de arte, ou como "gênero literário". O historiador inglês defendeu que o bom profissional da história deveria ser também, necessariamente, um bom contador de histórias, porque a história foi desde sempre, e será para sempre, na sua essência, uma forma de "representação da experiência passada" que exige um conjunto de qualidades no domínio da capacidade comunicativa (1986, p. 287-306).

${ }^{33}$ Hayden White fala da narrativa histórica como uma metáfora de longo alcance: "Como estrutura simbólica, a narrativa histórica não reproduz os eventos que descreve; ela nos diz a direção em que devemos pensar acerca dos eventos de valências emocionais diferentes. A narrativa histórica não imagina as coisas que indica: ela traz à mente imagens das coisas que indica, tal como o faz a metáfora. (...) A metáfora não imagina a coisa que ela procura caracterizar; ela fornece diretrizes que facultam encontrar o conjunto de imagens que se pretende associar àquela coisa. Funciona como um símbolo, e não como um signo: vale dizer, ela não nos fornece uma descrição ou um ícone da coisa que representa, porém nos diz que imagens procurar em nossa experiência
} 
A narrativa pretendida por nosso autor foi atraentemente escrita, propiciando a um leitor interessado conhecer e/ou compreender o passado através de um discurso que encanta, aproxima, integra e decodifica. O texto, inundado de descrições, detalhes, maravilhas e ações, alarga-se e se torna sempre mais estimulante, permitindo ao público entregar-se à imaginação das cenas e contextos e observar as personagens históricas como figuras vivas e não como caracteres enformados em prefigurações. A história, enquanto narrativa, fica, assim, mais completa, atraente e capaz de ser reconhecida e fazer reconhecer.

Heródoto faz o registro histórico visando atingir um público específico com suas Histórias, isto é, gregos do século V a.C. Este público tinha pré-configurações dos eventos, o saber-compartilhado (HARTOG, 1999), que deveriam ser reconhecidas na narrativa. Para atrair este leitor/ouvinte, o historiador de Halicarnasso conta a maioria das sequências históricas de inúmeras maneiras diferentes, fornecendo interpretações e sentidos diferentes. É interessante notar que, ainda que as representações fossem alternativas e mutuamente exclusivas, o mesmo conjunto de eventos configurava-se como plausível devido à forma engenhosa como foram as situações transformadas de trágicas para cômicas ou do ponto de vista do vitorioso para o do derrotado, alterando a percepção do fato a partir da codificação, se não criação, de enredos históricos. ${ }^{34}$

O processo de pesquisa e busca de fontes para a construção narrativa das Histórias resulta na "imparcialidade profissional" possível àquele que se propõe ter o homem e suas obras como "fonte de trabalho". Heródoto, enquanto pai da História, é aquele que se propôs tentar, em primeiro lugar, encontrar "o que aconteceu" e, então, explicar "o por que aconteceu", distinguindo os gregos de seu tempo de seus predecessores e, também, de seus sucessores.

culturalmente codificada a fim de determinar de que modo nos devemos sentir em relação a coisa apresentada" (WHITE, 1994, p. 108).

${ }^{34}$ White: "Vista de um modo puramente formal, uma narrativa histórica é não só uma reprodução dos acontecimentos nela relatados, mas também um complexo de símbolos que nos fornece direções para encontrar um ícone da estrutura desses acontecimentos em nossa tradição literária. (...) A narrativa histórica serve de mediadora entre, de um lado, os acontecimentos nela relatados e, de outro, a estrutura de enredo pré-genérica, convencionalmente usada em nossa cultura para dotar de sentido os acontecimentos e situações não-familiares" (1994, p. 105) 
"Ver-se a si próprio transformado diante de si mesmo e então atuar como se na realidade a pessoa 
tivesse entrado em outro corpo, em

outra personagem".

NIETZSCHE, O Nascimento da Tragédia

\section{MENSAGEIRO TRÁGICO}

\section{$3.1 \mathrm{O}$ narrador}

Ser historiador é ser narrador por excelência, pois ele diz algo sobre o humano. Ao "historiar", isto é, em seu processo de pesquisa histórica e construção de uma escrita convincente e sedutora, ele busca conhecer, se não decifrar, aquele e aquilo que lhe é alheio, diferente e distante quer nos hábitos, quer nos lugares ou tempos. O efeito desses processos de codificações é tornar familiar o não-familar e comunicar ao leitor os fatos ocorridos.

Tal qual a narrativa do historiador, a narrativa do mensageiro se dá à função de comunicar (a) pagge\&llein) situações, falas e objetos distanciados do recebedor no tempo e no espaço (BRANDÃO, 2005b, p. 48):

O termo grego com que Aristóteles define a ação do narrador é bastante significativo: apangéllon. Pode ser que, na escolha do vocábulo, ele tenha tido em vista uma função trágica bem definida, a do ángelos, o mensageiro que, com bastante regularidade, introduz na representação dramática a narrativa de ações passadas fora da cena. (2005b, p. 46-47)

Ao distinguir o drama da narrativa, Aristóteles emprega o termo a) paggeli \&a para designar antes o que faz o próprio narrador (poeta) que uma personagem dentro da fícção. ${ }^{35}$

\footnotetext{
${ }^{35} \mathrm{Na}$ Poética (1448a20), a) pagge\&llonta é utilizado no sentido de narrar, função atribuída ao poeta: “Com efeito é possível imitar os mesmos objetos nas mesmas situações, numa simples narrativa, ou pela introdução de um terceiro, como faz Homero (...)". Pouco mais adiante, em 1449b10, a) paggeli \&an é utilizado no sentido de forma narrativa, quando são colocadas em distinção a epopéia e a tragédia: "Quanto à epopéia, por seu estilo
} 
Parece-nos que, na verdade, o estagirita estabelece o narrador com mais uma voz no processo diegético e, embora somente a etimologia não demonstre que esta palavra fosse usada intencionalmente para nos remeter ao mensageiro, é sugestivo que tal personagem esteja ligada ao mesmo termo. Por isso cremos ser o uso de a) paggeli\&a, para distinguir a narrativa do drama, um excelente meio de pontuar a condição única do mensageiro no palco trágico (BARRETT, 2002, p. 69).

A nosso ver, embora claramente Aristóteles procure distinguir entre narrativa e performance de personagens fictícias, devemos considerar que o termo a) ggeli\&a contido referencial e etimologicamente na a) paggeli\&a do filósofo - em alguma medida escapa ao confinamento do palco. Isto é, não nos parece acaso que o termo utilizado para distinguir narrativa da tragédia seja tão próximo, se não idêntico, ao que designa o discurso do mensageiro (BARRETT, 2002, p. 70).

Pensando no historiador como aquele que emprega a forma narrativa (a) paggeli\&a) em seu discurso, buscaremos, primeiramente, a aproximação de Heródoto com o mensageiro (a!ggelov), sobretudo, na sua condição de viajante que, como narrador de lugares desconhecidos, apresenta ao homem grego o relato daquilo que estava fora de seu próprio olhar, que pertencia ao diferente, fazendo com que ele se tornasse outro, ou seja, se tornasse mensageiro, tendo a condição de convencer por ter presenciado: "Na narrativa de viagem, a inversão revela-se uma operação de tradução: trata-se de um dos procedimentos que permitem passar do mundo que se conta ao mundo em que se conta" (HARTOG, 1999, p. 232).

Encontramo-nos, ainda, nos domínios da história e da narrativa de acontecimentos, porém, sob o ponto de vista da ficção. Portanto, lança-se mão de todo um vocabulário de descrição ou de evidência de cena, uma vez que as descrições passam a não pressupor nenhuma testemunha enquanto fonte de veracidade. Apenas Heródoto testemunhara tudo o que contava, não tendo outro que depusesse a seu favor. Não se trata, portanto, do campo no qual testemunhas podem atestar a veracidade ou não do ocorrido, mas, sim, do campo da narrativa que deve ser coesa, bem articulada e conveniente de acordo com as intenções de convencer. A capacidade de fascinar (qe/lgein) era ponto fundamental para falar sobre o que alguém poderia, de fato, ver e/ou vivenciar.

Para quem se encontra imerso numa sociedade, a realidade lhe parece, muitas vezes, parte de uma ordem única e inalterável. Por sua vez, o viajante, ao contrário, estando fora de 
seu "universo" familiar, não se reconhece propriamente na nova paisagem na qual imerge e acaba tendo suas percepções estimuladas pelo que se lhe apresenta como novo e singular. É por meio do contraste com sua própria experiência cultural que pode desvendar, pretendendoo ou não, a natureza relativa dos eventos que descreve. Seu olhar será sempre o do outro. E é exatamente nisto que reside seu maior valor como fonte própria do narrado e de sua veracidade, pois, apesar das reações de desgosto, condescendência, êxtase etc., provocadas no espectador, o viajante será sempre dotado da capacidade e da possibilidade de dizer o que ninguém mais sabe.

Portanto, a diversidade, estando fora dos limites do que o público podia ver, estava ao alcance somente daquilo que podia ser dito pelo mensageiro e ouvido por seu recebedor. $\mathrm{O}$ outro tinha, pois, uma identidade reconhecida pelo fato antagônico de escapar dos limites dos olhos do espectador, por estar além da visibilidade do que se contempla no espaço da cena e, por isso mesmo, ser diferente. Ou seja, é uma identidade deslocada ao não se dar naquilo que se colocava diante dos olhos do público, mas, sim, numa esfera do que pode ser dito e ouvido, na qual existe apenas o discurso e a narrativa de alguém em quem se deve crer, o mensageiro/narrador.

De fato, o mensageiro na tragédia grega é frequentemente considerado como uma figura que faz relatos sobre os eventos acontecidos fora do palco, portanto, desconhecidos. Ele viu e vê aquilo que os outros jamais poderão observar. Tendo autoridade por dizer aquilo que viu, sua narrativa torna-se ainda mais admirável para o público porque faz ver no presente os rostos, as silhuetas, as cenas quotidianas etc. daqueles que estão fora do olhar do espectador. Nessa condição, ele se caracteriza como uma personagem ligeira, confiável e que “conta tudo". Dado que a ele está reservado um papel essencialmente descritivo, muitos são os estudiosos que referem a objetividade, factualidade e racionalidade como características que se enquadram perfeitamente ao seu discurso. Contudo, acreditamos que uma leitura mais atenta dos episódios dos quais tal personagem faz parte deixam transparecer marcas de subjetividade.

O mensageiro trágico relata os fatos e não mente, embora muitas vezes os fatos possam por ele ser ficcionalizados. Na verdade, ele nem sempre conta toda a história e, algumas vezes, seria mesmo impossível que o fizesse ou que tivesse presenciado tudo o que narra. De fato, ele não é somente testemunha visual do evento, mas é, também, o único que presenciou a cena narrada. O espectador, por sua vez, não vê os eventos por si mesmo, é, ao contrário, ouvinte de uma notícia dada sobre eles. Portanto, esses eventos podem, simplesmente, serem apresentados com uma versão mais ou menos detalhada: detalhes estes 
introduzidos para dar cor e sentido às histórias. E isso é possível pela razão de estarem os eventos sendo apresentados através dos olhos de outro que não o próprio espectador; um outro que, muitas vezes, está, ele próprio, envolvido nos acontecimentos.

É relevante, então, que o espectador não só não via os eventos por ele mesmo, como os via pelos olhos do narrador. Ressaltamos, de forma importante, que Heródoto, tal qual a personagem trágica, tem a oportunidade de manipular a apresentação destes mesmos eventos, utilizando-se de técnicas de narrativa e dramatização, escolhendo palavras de forma a gerar significados, utilizando e selecionando os fatos de acordo com a necessidade que se apresenta ao convencimento de seu público, de forma a enaltecer suas histórias e permitir aos ouvintes transportarem-se a diversos lugares, ao introduzir a variedade por meio de diversos episódios.

Nessa condição, "o mensageiro Heródoto" torna-se alguém apto a inferir os pensamentos ou motivos mais íntimos das personagens de sua narrativa, a partir da sua mais pessoal percepção de suas ações e palavras. De maneira similar ao que afirmamos sobre o historiador de Halicarnasso, afirma Irene Jong em relação ao mensageiro em Eurípides: "Além disso, como nós devemos ver, o mensageiro em Eurípides tende a inferir os pensamentos e motivos das outras personagens a partir de suas ações ou palavras" (1991, p. 14. Tradução nossa). ${ }^{36} \mathrm{Na}$ Medéia de Eurípides, por exemplo, o mensageiro infere o que a velha criada pensou (do/casa) no momento em que a filha de Creonte, de repente, mudou de cor e caiu em seu trono:

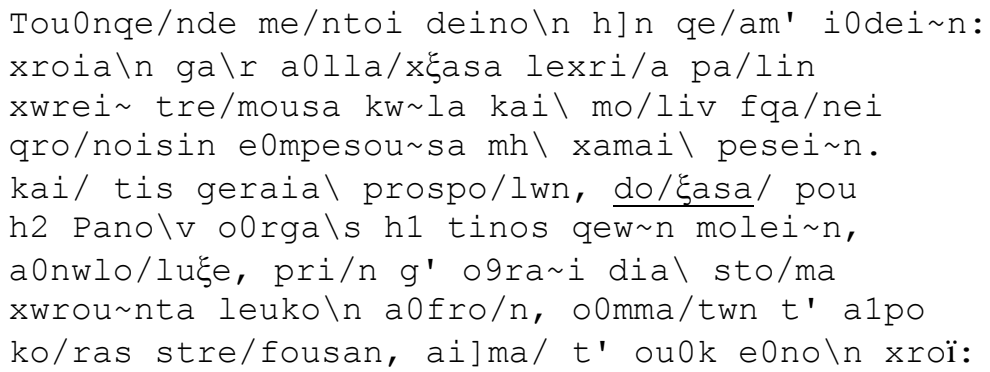

Depois todavia foi terrível espetáculo: mudou de cor e pendeu de lado, com tremor nos membros; a custo alcançou o trono sem cair no chão. Uma velha serva, por lhe parecer a vinda de um acesso de Pã ou de um Deus, alarideou até ver escorrer pela boca a espuma branca e as pupilas dos olhos girarem e o sangue sumir da pele. (EURÍPIDES, v. 1167-1175. Grifo nosso)

\footnotetext{
36 "Moreover, as we shall see, the Euripidean messenger tends to infer other characters' thoughts and motives from theirs actions or words"
} 
De fato, temos que o mensageiro, como primeiro e único visualizador de tal cena, torna sua a percepção de outra personagem, no relato transcriado de seu texto, como se pudesse olhar dentro do próprio coração da outra. Nesse trecho notamos a semelhança com o discurso do próprio Heródoto:

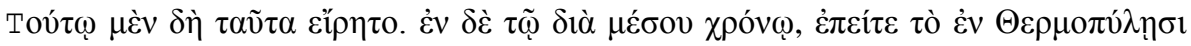

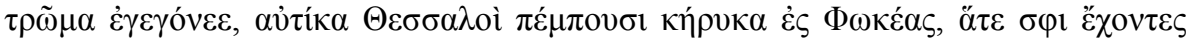

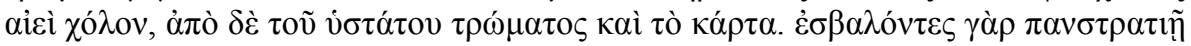

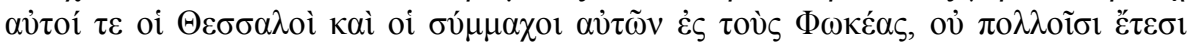

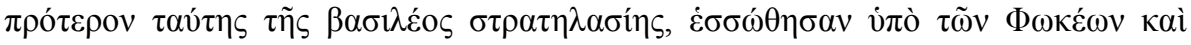

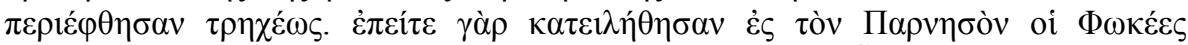

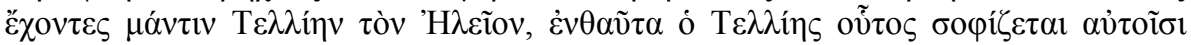

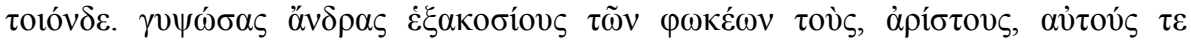

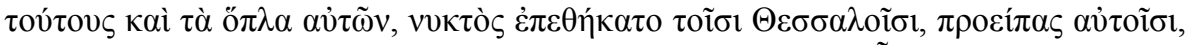

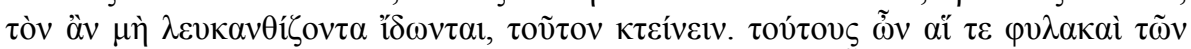

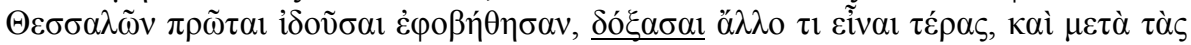

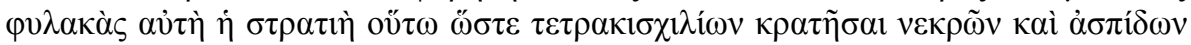

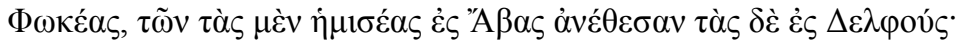

Foram estas as suas palavras, nesse intervalo de tempo, a seguir ao desastre das Termópilas, os Tessálios enviaram de imediato um mensageiro aos Focenses, a quem guardavam um rancor inabalável, sobretudo desde a última derrota. $\mathrm{Na}$ verdade quando, não muitos anos antes desta expedição do Rei, os Tessálios e os seus aliados caíram, com todas as suas tropas, sobre os habitantes da Fócida, foram por eles vencidos e muito mal tratados. Acossados no monte Parnasso, os Focenses tinham consigo um adivinho, Télias de Élide, que na ocasião traçou o seguinte plano: depois de cobrir de cal o corpo e as armas de seiscentos dos mais valorosos Focenses, fê-los avançar de noite contra os Tessálios, com a recomendação de matarem todo aquele que não vissem pintado de branco. Os primeiros a perceber sua presença foram os sentinelas tessálios, que, julgando tratar-se de algum ser sobrenatural, entraram em pânico - tal como, depois deles, todo o exército. De tal maneira que o inimigo conseguiu tomar quatro mil cadáveres e os respectivos escudos, de que uma metade foi dedicada como ex-voto no templo de Abas e a outra no de Delfos. (VIII, 27. Grifo nosso)

Esta habilidade do mensageiro em ler a mente de outras pessoas não é em si mesma irrealística: ele vê o que está acontecendo e pode inferir, a partir das palavras e ações de outras personagens, a visão que estes ou estas tiveram do evento (JONG, 1991, p. 24-25). Isso fica claro no exemplo seguinte, de As Fenícias:

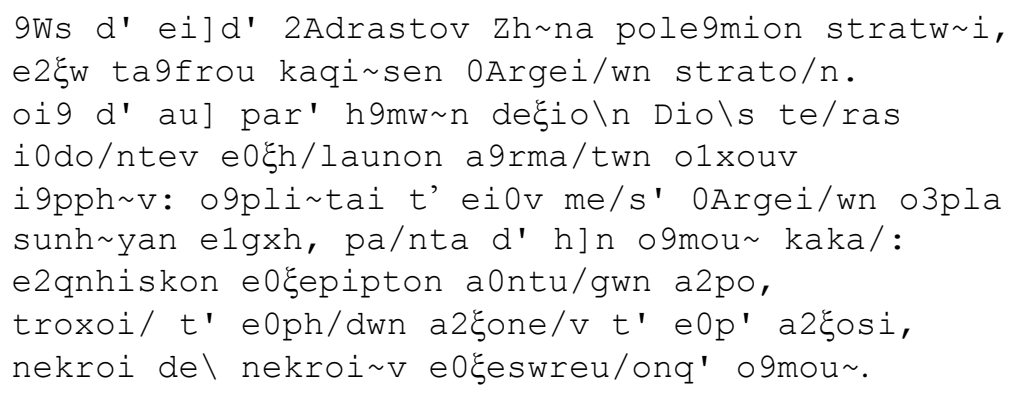

Ádrasto, vendo Zeus voltar-se contra ele, levou seus comandados para além do fosso. 
Nossos soldados, ao contrário, observando estarrecidos o prodígio, perceberam que Zeus tomara a decisão de os ajudar. Num átimo, carros, infantes, cavaleiros saíram por todas as portas das muralhas e começaram a lutar contra os argivos, que foram vítimas de um desastre completo; caindo de seus carros eles eram mortos; rodas e eixos voavam seguidamente, e caíam cadáveres sobre cadáveres. (EURÍPIDES, v. 1187-1195)

Frisamos, aqui, então, que os mensageiros são, por sua própria natureza, testemunhas visuais que relatam batalhas, lugares e ações com ênfase em seu próprio processo de aOutoyi/a:

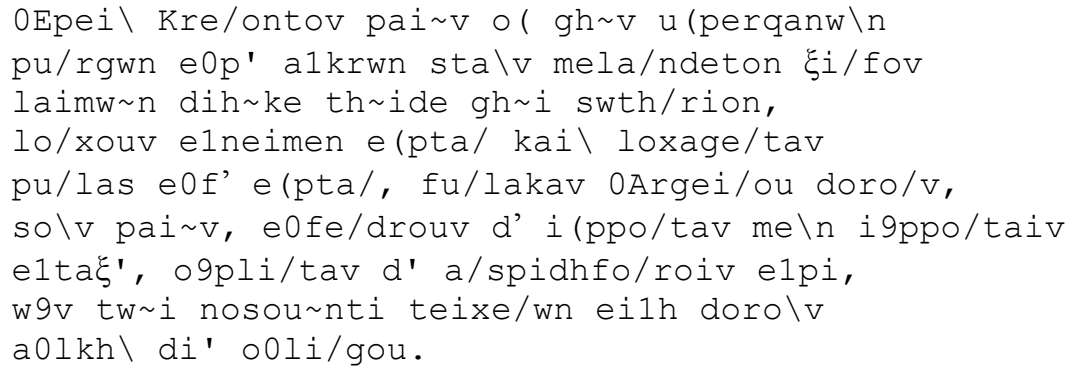

De pé na crista de nossas altas muralhas

o filho de Creonte, para dar a vida por sua pátria amada, acaba de enterrar com toda a força a espada escura no pescoço, livrando assim da perdição Tebas antiga.

Teu filho Etéocles mandou na mesma hora às nossas sete portas sete batalhões com os respectivos comandantes, no intuito de repelir os contingentes dos argivos; ele ordenou que cada cavaleiro nosso ficasse em frente a cada cavaleiro deles e fez o mesmo em relação à infantaria, alerta para socorrer num instante a parte das muralhas mais ameaçada. (EURÍPEDES, As Fenícias, v. 1090-1098)

Assim, eles acabam por se colocarem como "pseudo-historiadores" que se esforçam para ressaltar a veracidade de seu relato (JONG, 1991). Justamente por terem testemunhado determinadas coisas e por necessitar convencer acerca de sua verdade, os mensageiros contam com o fato de serem personagens da tragédia, bem como o nosso historiador pode contar com a função teatral de ser um alggelov para os gregos, colocando-se no papel do espectador dos eventos:

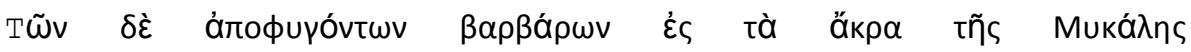

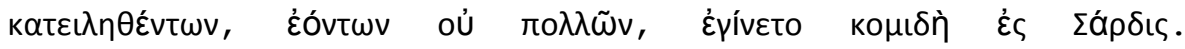

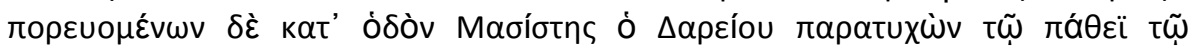

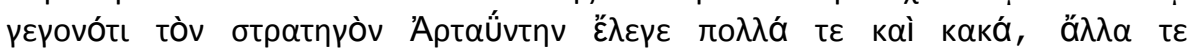




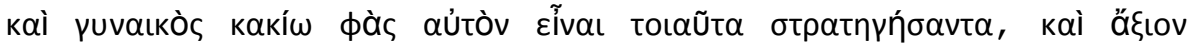

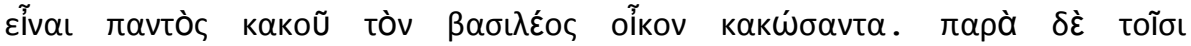

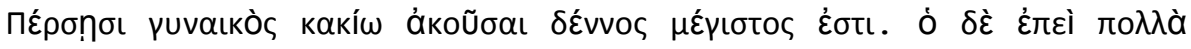

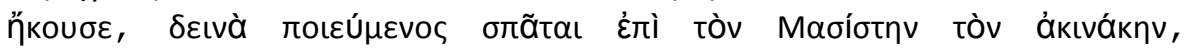

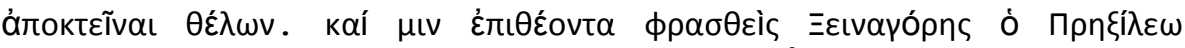

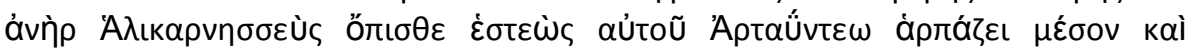

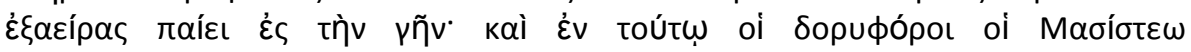

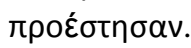

Enquanto navegaram para o Helesponto, o pequeno número de bárbaros que haviam escapado ao desastre se retirara para o cimo do monte Mícale e dirigiu-se para Sardes. Masistes, filho de Dario, presente à batalha perdida pelos Persas, fez, em caminho, acerbas censuras ao general Artaintes, e, entre outras injúrias, disse-lhe que desobrigando-se, como havia feito, das funções de general, mostrara-se mais covarde do que uma mulher, merecendo, por isso, ser impiedosamente castigado pelo mal causado à casa real. Ora, entre os Persas, constitui o maior ultraje que se pode fazer a um homem dizer-se que ele é mais covarde do que uma mulher. Indignado com tamanha injúria, Artaintes tirou da cimitarra para matar Masistes; mas Xenágoras, filho de Praxilas de Halicarnasso, que se achava atrás do agressor, vendo-o avançar para Masistes, agarrou-o pelo meio do corpo e atirou-o por terra, enquanto os guardas de Masistes acorriam em sua defesa. (HERÓDOTO, IX, 106)

Quando caracterizamos o mensageiro como uma testemunha visual, damos a ele a condição de ser bastante teatral nos seus relatos: "todo narrador é um focalizador e, como tal, apresenta a narrativa em questão com algo a mais ou a menos que uma representação transparente" (BARRET, 2002, p. 23. Tradução nossa). ${ }^{37}$ Sua posição será não só a de dizer ao espectador - na encenação do teatro ou na leitura das Histórias, mas, também, às personagens - o que eles todos não viram. Por isso, a fala do outro, quer do mensageiro, quer daqueles sobre quem contam algo os mensageiros, é movida pela intenção de se levar ao conhecimento, ao divertimento e, pela demonstração do diferente, certificar o espectador de que tudo o que se narrava em cena, fora da cena, era um ato verídico e/ou verossimilhante. Percebemos que tanto o discurso do historiador, quanto o discurso do mensageiro deveriam conseguir ser críveis aos seus públicos: "os aspectos da recepção são o principal fio condutor da reflexão, entendido que o objetivo do escritor é agradar (aréskein) e o valor da obra depende de como ela é julgada pelo público" (BRANDÃO, 2005b, p. 55). Nesse contexto, as razões do historiador para contar versões nem sempre verdadeiras são as literárias e as artísticas e esse é um ponto central de nosso trabalho.

Mas, considerando que ora tratamos de uma personagem do teatro, há de se perguntar por que os acontecimentos narrados pelo mensageiro não são encenados. A motivação mais importante é que, tradicionalmente, certos eventos não eram mostrados no palco, mas

\footnotetext{
37 "Every narrator is a focalizer and as such renders the narrative in question something both more and less than a transparent representation".
} 
relatados oralmente. ${ }^{38}$ Irene Jong (1991, p. 117-118) apresenta cinco razões como resposta à questão: a presença do coro, que tornava a substituição das cenas praticamente impossível; o coro que atuava em cenas em grupo; milagres que não podiam ser mostrados no palco; assassinatos no palco não eram passíveis de representação; e, por fim, o fato de terem sido os discursos dos mensageiros muito apreciados pela audiência, o que pode ter levado a uma competição, entre os dramaturgos, por continuar a incorporar em suas peças tais personagens, dando a eles, de fato, bastante atenção, embora não fizessem deles uma das personagens principais. $^{39}$

De fato, há um surpreendente interesse no status do mensageiro, firmemente ancorado nas peças teatrais. Mas de que modo o a!ggelov é apresentado e quais são as indicações dadas aos espectadores como forma de reconhecê-lo? Eles são convencionalmente identificados nos manuscritos por suas funções: pastor, ${ }^{40}$ servo $^{41}{ }^{4}$ soldado, $^{42}$ escravo $^{43}$, espião ${ }^{44}$ etc. ${ }^{45}$ Segundo Jong (1991, p. 64) o mensageiro era um outsider, isto é, alguém na

\footnotetext{
${ }^{38}$ Os relatos dos acontecimentos extracênicos, que não podiam, convencionalmente, ser apresentados ao público, eram tais como os de morte de alguma personagem ou eventos bélicos que, frequentemente, desencadeavam uma mudança que conduzia à catástrofe, pois, irremediavelmente, as mensagens transmitidas carregam em si conteúdo extremamente dramático e capaz de desvelar a trama da história.

${ }^{39}$ A autora em questão ainda alega que uma indicação de que os discursos do mensageiro eram populares é a frequência com que tais personagens são ilustradas nas cerâmicas da época (1991, p. 118).

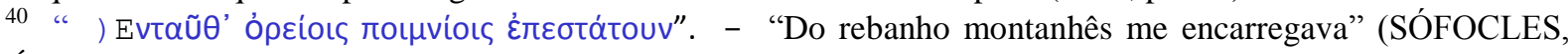
Édipo Rei, v. 1028).

\begin{tabular}{|c|c|c|c|c|c|c|}
\hline $41 \quad 41$ & ) $A l 1$ ', & $\mathrm{w}]$ & pi\&lh & de\&spoina, & $\mathrm{pa}=\mathrm{n}$ & peuksei \\
\hline$l e \& c w$ & $d^{\prime}$ & a) p' & a) $r x h=v$, & $\mathrm{h} ! \mathrm{n}$ & $m h \backslash$ & sfalei=sa\& \\
\hline
\end{tabular}

gnw\&mh tara\&chi glw=ssan e) n lo\&goiv e)mh\&n. - "Saberás tudo exatamente sem demora, senhora minha; meu desejo é te contar todos os fatos na sequência em que ocorreram, se não me emocionar demais na descrição" (EURÍPIDES, Ifigênia em Áulis, v. 1540-1542).
] W fi\&ltat',
$\mathrm{h}]$
pou
cumfora $\backslash n$
h\#keis
pe\&rwn
) Eteokle\&ouv qano\&ntov, ou[ par' a)spi\&da

be\&bhkav a) ei \, polemi\&wn eilrgwn be\&lh; - "Não vens, meu caro, anunciar, espero, alguma desgraça, a morte de Etéocles. Quem lhe conduzia o escudo, pronto para defendê-lo de lanças inimigas, eras tu" (EURÍPIDES, As Fenícias, v.1072-1074).

${ }^{43}$ ]W dw=m' o\# pri\&n pot' eu)tu\&xeiv a)n' 9Ella\&da, Sidwni\&ou ge\&rontov, o\#v tol ghgenelv drakkontov elspeir' olfeov e) n gaikai qe\&rov, w\#s se stena\&zw, dou=lov w!n me \n, a)ll' o\#mwv xrhstoi=si dou\&loiv sumfora ta $\backslash$ despotw=n. - "Ah! Casa outrora florescente em nossa Tebas do ancião de Sídon que lançou aqui os dentes do dragão filho da terra! Choro! Choro por ti, embora seja um mero escravo, mas os bons servidores sempre participam de todas as adversidades de seus donos" (EURÍPIDES, As Bacantes, v. 1025-1029).
}

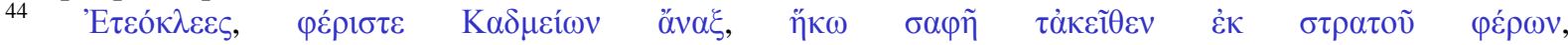

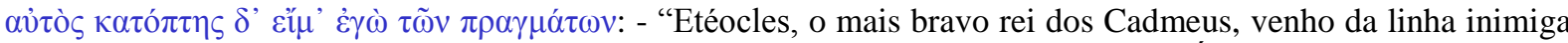
trazendo notícia fidedigna. Pois sou, em pessoa, o observador dos acontecimentos" (ÉSQUILO, Os Sete Contra Tebas, v. 39-42).

${ }^{45}$ Como temos argumentado, o mensageiro reporta ações importantes, as quais tiveram lugar fora do palco, sendo uma figura familiar tanto para a audiência quanto para os leitores da tragédia grega e, de fato, sua a) ggeli\&a, isto é, seu discurso é uma das mais bem conhecidas convenções da tragédia. É interessante observar que são duas as figuras responsáveis pelo relato e transmissão de informações: o mensageiro (a!ggelov) e o arauto ( $k h=r u c)$. Ambas as personagens preenchem um link vital da cadeia de comunicação, mas, na verdade, existem diferenças significativas em sua condição e no tipo de informação que eles transmitem. Por transmitir uma mensagem, um arauto sempre é um mensageiro, mas a fórmula contrária não é verdadeira. 
condição de forasteiro ou à parte do meio social descrito, tendo a incumbência, seja em que ofício for, de comunicar, de dar notícias sobre os fatos. Podemos, então, com boas razões e depois de tudo que foi dito, afirmar que o embrião a partir do qual se desenvolve o drama deve ser constituído pelo (re)conto do mensageiro e, precisamente, por uma série de a) ggeli\&ai inseridas nas cenas reportadas (GREGORIO, 1967, p. 39).

Sendo assim, temos dois elementos peculiares na narrativa da personagem: ele se comporta como um mensageiro porque, de acordo com o que podemos perceber, antecipa situações que sucessivamente recupera e especifica, e porque, com as circunstâncias dos fatos e a descrição dos locais, constrói uma narrativa particular, como testemunha ocular, isto é, aquele que viu com os próprios olhos tudo aquilo a que se refere (GREGORIO, 1967, p. 67).

\subsection{A narração}

Trataremos agora do discurso do mensageiro sob o aspecto da narração, considerando mais sua função dramática e buscando enfocar sua dimensão performativa, menos que sua função na estrutura da peça teatral. De certo modo, buscaremos enfatizar ainda mais, por sua aproximação ao mensageiro, Heródoto como um narrador de histórias e menos como um escritor de fatos históricos.

O mensageiro dá notícias, em seus discursos, de partes do enredo que são indispensáveis ao entendimento da trama, ou seja, o discurso dele é indispensável à compreensão do desenvolvimento da ação encenada. Todavia, não podemos perder de vista que se trata de uma narrativa, ou melhor, de uma representação verbal das ações e não das ações performadas no palco.

Mas como essa "narratividade" se expressa propriamente? A narração caracteriza-se, sobremaneira, pela mediação, mais ou menos presente, de um narrador entre as personagens

Eles partilham a qualidade de falarem por outros e performatizam a função de mediadores, movendo-se entre o remetente e o destinatário de um pronunciamento. Contudo, o arauto possui um status social maior que o do mensageiro e, na maior parte do tempo, é encarregado de uma variedade de ofícios, os quais incluem atuar como um emissário do rei, tomar lugar em sacrifícios religiosos e convocar os homens às assembléias públicas. Diferentemente do a!ggelov, que, aliás, como acabamos de demonstrar, ocupa diferentes funções, o kh=ruc não origina as mensagens que transmite, mas é enviado por seus superiores como alguém capaz de levar proclamações oficiais. Eles diferem, então, por ser o primeiro um tipo de mensageiro espontâneo, isto é, aquele que surge pela oportunidade de ter sido testemunha visual dos eventos dos quais dá notícia, e o segundo, por ser aquele que anuncia notificações oficiais ou comandos reais (DICKIN, 2009, p. 1). 
representadas. Essa mediação é realizada pelo discurso do mensageiro, que atua na tragédia grega através do tempo da narrativa, do local, das personagens e dos eventos.

Temos considerado, aqui, o alggelov como aquele que traz uma mensagem, constituindo-se como a única forma de intercurso entre os homens. Seu discurso é único em mostrar o que não pode ser encenado diretamente no palco e o conhecimento dos eventos se dá, assim, no presente, embora não necessariamente ele narre o que ocorre no exato momento em que se profere o discurso, pois pode comunicar algo sobre o que ocorreu em passado próximo. Na verdade, o fato é presentificado em cena pelo mensageiro, raramente excedendo o período de um dia ou alguns dias.

Aqui, as histórias não são, portanto, tomadas pelo que significam imediatamente, mas por sua aparência mediata, podendo ser apreendidas e corporificadas como uma espécie de atualidade pelo ouvinte. Esta espécie de corporificação engedra, em face da palavra encenada, de seu teor e de sua força, uma forte relação com o pensamento discursivo das personagens e do espectador. Para este, a palavra é um veículo para o estabelecimento de uma ligação entre os conteúdos intuitivo, singular, momentâneo e presente. Já para a personagem do mensageiro, o sentido do pensamento discursivo aflora na confecção e expressão de signos ou símbolos, cujo conteúdo não pode ser discernido apenas em um “estar presente", mas, antes, nas relações de pensamento que institui entre a história que narra e a própria percepção de seu interlocutor. Assim, a palavra encenada acaba por se interpor entre os diferentes conteúdos perceptivos, tal qual se impõe, também, à consciência no imediato aqui e agora. Saindo, então, da percepção imediata, a palavra confere a essa mesma consciência liberdade e agilidade para mover-se entre um conteúdo e outro e concectá-los entre si numa relação mediata.

Como narrador, o mensageiro constrói uma história dos "dramas" da vida humana. Nesse sentido, quando narra os eventos ocorridos no tempo que lhe é requisitado, sua narrativa é elaborada repleta de detalhes pitorescos, tendo a descrição das cenas e ações grande vivacidade, e as personagens e estados da sociedade não ficam relegados a uma súbita análise de motivos. Como está inserido em um espetáculo, a personagem compõe para o espectador a imagem das situações descritas repletas de detalhes, formas, movimentos e falas. Por sua vez, na narração das Histórias, Heródoto faz uso de metáforas, de estratégias de persuasão e da interação com um interlocutor através das manifestações de emoções expressas pelas interjeições, vocativos, dúvidas e imperativos, possibilitando a aproximação de sua narração do discurso da personagem do mensageiro (a!ggelov) trágico, colocando-o em uma condição entre a história e a ficção e fazendo dele um artista da palavra. 
Segundo Brandão, "o elemento mais basicamente definidor da narrativa é o narrador" (2005b, p. 93). Então, como elemento definidor da narração, entendemos que Heródoto utiliza-se da dramatização dos eventos como uma alternativa de construção do discurso, tornando aquela mais sedutora e interessante ao seu público. Lembremos que, na tragédia, a intenção do al gge lov estava em constante relação com seu interlocutor e, atendendo ao seu anseio, a narrativa ganhava a finalidade de retratar o outro lado da história, exterior à própria história acontecida/narrada através da fala de personagens que a viveram e, portanto, podiam ver os fatos de modo singular em seu próprio mundo, pois as notícias repassadas atuam, antes de tudo, no destinatário: é para ele que o efeito é calculado pelo narrador, sendo nele que o texto deve fazer efeito.

O foco da narrativa do mensageiro e da narrativa de Heródoto centra-se na expressão e uso de fatos que tornam latentes os eventos na sua própria mente e na daqueles a quem narra, sublinhando a relação idiossincrática de ambos em relação à sucessão dos eventos narrados. Como vimos ao longo deste capítulo, a) paggeli\&a é a narrativa a alguém daquilo que não foi visto e o mensageiro é justamente aquele que traz à tona a verdade porque está fora do próprio teatro ou da cena. Assim também Heródoto ganha veracidade para sua narração por estar fora da Hélade e contar aos helenos o que sua curiosidade pedia acerca de terras distantes, de acordo com aquilo que ele próprio atestou em suas pesquisas. Queremos dizer que, ao narrar sob o seu ponto de vista, a técnica de narrativa utilizada pelo mensageiro e por nosso historiador, isto é, a utilização de conhecimentos externos e mistura de realidade e ficção, fornece ao espectador o resultado dos eventos de acordo com a sua percepção e, ainda, ao mesmo tempo, partilha com eles a experiência e a possibilidade de reconstrução destes mesmos resultados, no momento de seu reconto pela transcriação do que fala e daquele que o ouve.

Queremos dizer que, ao recontar os eventos desde o princípio e em detalhes, o discurso do mensageiro (a g ggelikh \r(h=siv) narra de acordo com o foco de sua experiência, isto é, da forma como eles foram entendidos ou falharam ao entendimento da personagem no momento de sua ocorrência. Porém, para os discursos do Heródoto mensageiro serão apresentados certos critérios de veracidade, tais como datações, localizações e personagens envolvidas, de forma que o historiador viajante ou o mensageiro de e em terras/cenas alheias possa conquistar a convicção de sua audiência para sua própria ideia de um universo de verdade: 


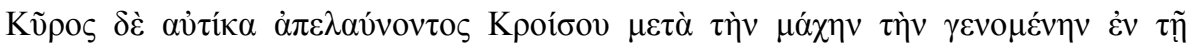

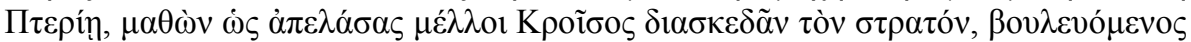

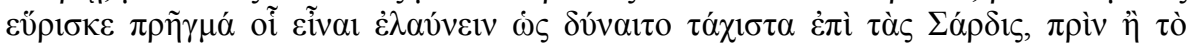

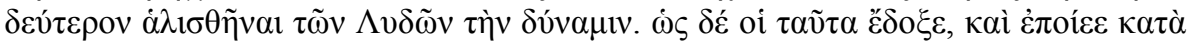

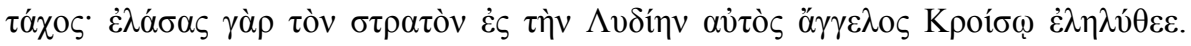

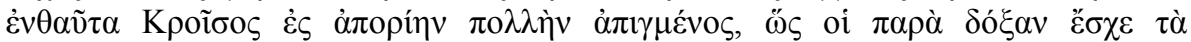

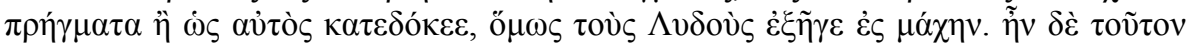

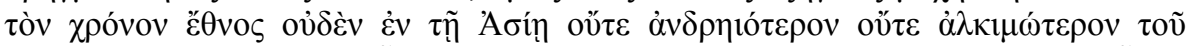

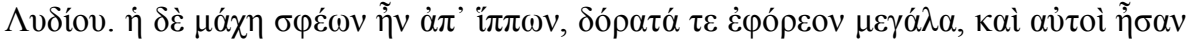
i $\pi \pi \varepsilon v ́ \varepsilon \sigma \theta \alpha \iota \dot{\alpha} \gamma \alpha \theta$ oí.

Ciro, logo que Creso partira após a batalha travada em Ptéria, ao ter conhecimento que ele, terminado o regresso, tinha intenção de licenciar o exército, reflectiu e chegou à conclusão de que o objectivo era marchar contra Sardes o mais rápido possível, antes que de novo se reunissem as forças dos Lídios. E, uma vez tomada esta resolução, executou-a sem detença: penetrou com o exército na Lídia e, da sua chegada, ele mesmo levou a notícia a Creso. Então este encontrou-se em grave apuro, porque as coisas corriam ao contrário do que pensava ou do que esperara. Apesar disso, conduziu os Lídios ao combate. Não existia naquele tempo, na Ásia, povo algum mais valoroso e mais poderoso do que os Lídios. Combatiam a cavalo, munidos de duas longas lanças, e eles próprios eram excelentes cavaleiros. (HERÓDOTO, I, 79)

Desta forma, a resposta emocional do espectador é programada para a sequência dos eventos, que passam a ser contados em ordem cronológica, para que a narrativa se torne mais lúcida. $\mathrm{O}$ que este discurso tem de peculiar é o fato de oferecer à audiência o que anteriormente era sabido apenas por rumores e, ao mesmo tempo, lembrá-la de que o mensageiro sabe o que vem a seguir, como, por exemplo, em As Fenícias:

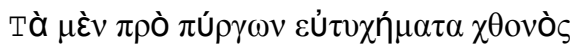

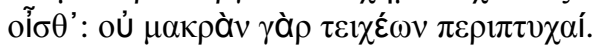

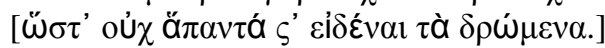

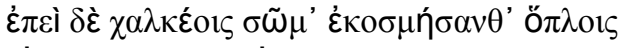

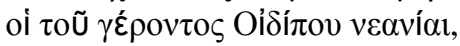

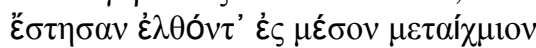

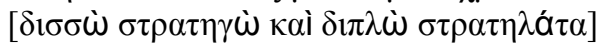

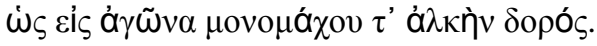

O que sucedeu diante dos muros da cidade sabes. Os arredores não se alargaram tanto que não possas conhecer tudo. Depois de revestirem o corpo com armadura de bronze, os florescentes filhos do idoso Édipo se perfilaram, tomaram posição no campo que separa os dois exércitos. Lá se encontravam os generais, os dois comandantes de tropas para a luta singular na força da lança. (EURÍPIDES, v. 1356-1363)

\subsubsection{Narração e mimese}


Segundo Hayden White, após considerarmos o discurso enquanto um gênero a ser analisado, devemos considerar que esta análise deve ser feita "no nível da descrição (mimese) dos 'dados' encontrados no campo da investigação que está sendo demarcado ou investigado para a análise" (WHITE, 1994, p. 17). Já estabelecemos o discurso do mensageiro e o discurso herodotiano enquanto gênero de análise; passaremos, pois, à análise no nível da mimese.

Acreditamos que a narrativa herodotiana tem a marca da diferença. Essa marca estaria, em princípio, no fato de misturar realidade e ficção, verossímil e fantástico, ou seja, de ser surpreendente em vista das expectativas alimentadas pelo público a que se dirige. É na mistura que reside o que há nela de original, mais que na estranheza ou na novidade. Ela encontra no composto, na mistura e na soma sua própria identidade. É justamente sobre essa mescla de ficção e fato que ora nos referiremos, ou seja, trataremos dos processos de representação e de como eles se aparentam intencionalmente no discurso, construindo a representação que constitui a realidade.

Aristóteles afirma na Poética 1460a15-25: "todos quantos narram alguma coisa acrescentam pormenores com o intuito de agradar. É preferível escolher o impossível verossímil do que o possível incrível”. Parece-nos que esta condição - a escolha do impossível verossímil - é o próprio critério de verossimilhança utilizado na comunicação entre o discurso do mensageiro e público. $\mathrm{Na}$ mimese das ações, isto é, na imitação da realidade, o que se coloca em questão é mais a legitimidade da narração que uma verdade única.

Ao proferir suas palavras, o mensageiro busca estabelecer com a audiência um critério de verossimilhança, que seria o de utilizar a fala de outras personagens na sua, dando uniformidade à narrativa. Dentro das situações cênicas, encontramos três formas de narrativa: a simples - a personagem fala por si mesma em primeira pessoa; a mimética - a personagem reproduz a fala de outras personagens; e a mista - as duas primeiras formas de narrativa se alternam dentro da mesma fala. ${ }^{46}$

Em grande extensão, nas falas do mensageiro seu discurso prevalece sobre o dos outros, isto é, o narrador fala mais por si mesmo. O papel dessa estratégia discursiva seria realçar a responsabilidade da personagem pelo narrado e distanciar o recebedor com relação à narrativa. Na verdade, nas situações em que o mensageiro se coloca explicitamente na cena, utilizando-se da primeira pessoa, ele tende a se fortalecer contra o pano de fundo da história,

\footnotetext{
${ }^{46}$ A classificação da narrativa em simples, mimética e mista está em Platão, na República. Não nos interessa, todavia, estabelecer discussão sobre ela. Para mais detalhes, cf. BRANDÃO, 2005b, p. 40-46.
} 
enquanto responsável pelo desenrolar do enredo. Podemos perceber essa característica no trecho da Medéia que transcrevemos a seguir; nele, nos versos finais, o mensageiro ainda nos lembra de seu papel como narrador fazendo um julgamento da situação que acabara de descrever: a morte da princesa, filha de Medéia, e de Creonte, o rei. Portanto, vemos que a narrativa não é apenas marcada pela voz do narrador desde o seu início, mas, sim, sinalizada por um narrador que tem consciência de seu papel e faz isso transparecer para o recebedor:

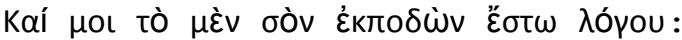

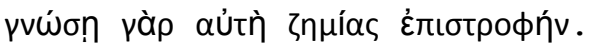

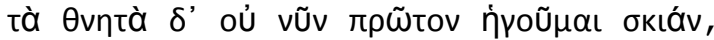

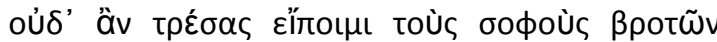

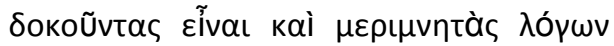

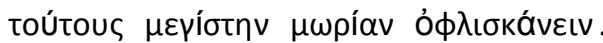

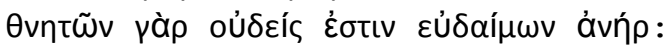

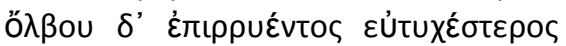

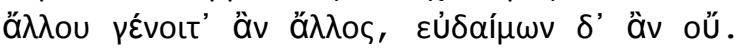

Quanto a ti, não sei o que considerar, pois só a ti cabe saber como escapar à punição. Não é esta a primeira vez que vê a vida apenas como uma sombra que se agita, e, sem medo de errar, afirmo que os que se julgam mais sábios são os mais castigados por sua tolice. Pois nenhum ser mortal é feliz; a fortuna pode sorrir a um e fazê-lo mais feliz do que os outros. Mas feliz nenhum é. (EURÍPEDES, Medéia, v. 12221230)

O discurso do mensageiro é um discurso longo e contínuo, no qual, como já dito, os eventos ocorridos fora da cena tomam seus lugares e o seu conteúdo é a narrativa da primeira pessoa, ou melhor, daquele que sabe contar porque viu, isto é, o mensageiro. Contudo, uma característica fundamental deste tipo de narração é a de que o narrador pode optar por narrar os eventos exatamente como os experimentou e compreendeu no momento em que se passaram $^{47}$ ou optar por narrá-los de acordo com o foco que intenciona dar à sua narrativa, forma na qual é permitida a utilização dos conhecimentos dados fora dos eventos, mas que servem para atestá-los e dar a eles maior grau de convencimento e veracidade. $\mathrm{O}$ discurso do mensageiro funciona como um reflexo no espelho, no qual a ilusão/imagem e a realidade se confrontam, gerando a história. ${ }^{48}$

\footnotetext{
${ }^{47}$ Nessa condição, a de narrador das próprias e particulares impressões, o mensageiro é nada mais que um ser humano com suas limitações de poder dizer somente o que viu, considerando limitações a posição física na qual se encontrava no momento do acontecido, seu acesso ordinário à mente das outras personagens e seu entendimento em relação aos fatos. Sobre estas restrições em relação à figura do mensageiro cf. JONG, 1991, p.12-15.

${ }^{48}$ Como imitação da realidade, é necessário à narrativa mimética espelhar-se no exterior, para que ganhe uma existência concreta e possa ser percebida pelo leitor ou pelas demais personagens. É, pois, a expressão dramática dos pensamentos e dos sentimentos, realizada seja por intermédio da narração, seja por intermédio do diálogo, que cria o link entre a ficção e a realidade (BRANDÃO, 2005b).
} 
A aplicação da verossimilhança como ponto de convencimento é aqui ponto-chave, aparecendo na presença de grande número de detalhes na descrição das pessoas ${ }^{49}$ e lugares, ${ }^{50}$ e nos nomes que são especificamente declarados, bem como nas histórias por trás de suas origens e numa grande quantidade de tempo que também é dedicado às especificações e digressões ${ }^{51}$, revelando-nos os costumes ou as características do grupo em discussão. ${ }^{52} \mathrm{O}$ uso dessa técnica de narração, de acordo com o foco da experiência de um indivíduo em [particular, torna possível transportar a audiência ao passado e presente que se quer dar ao conhecimento, isto é, o narrador/mensageiro faz com que os ouvidos de seu público se transformem numa espécie de testemunha visual (JONG, 1991, p. 38-39).

Por sua vez, quando nos deparamos com uma narrativa mimética, ou seja, quando passa a haver a pura imitação da realidade através falas das personagens. Isto é o que caracteriza o teatro. A mimese é pensada como apresentação, ou movimento mínimo de enfatização que destaca ou recorta, do mundo natural, algo que se faz passar por ele e que provoca, naqueles a que se dá a ver, os efeitos que seriam necessariamente provocados se fosse o mundo mesmo que estivesse lá. Nesse contexto, narrador já não mais representa a si mesmo para público, isto é, temos algo como a narrativa sem narrador. Sua estratégia discursiva depende justamente do ocultamento dessa função, para que toda luz se jogue sobre a narração e a ação das personagens. $O$ mensageiro, sob essa perspectiva, despersonaliza-se da condição de produtor de um discurso particular para representar o papel de veículo de um discurso outro que não o seu.

Porém, temos ainda que considerar o recurso ficcional de fazer falar as personagens presentes em um cenário que não o em questão no momento da cena é bastante relevante em si. As personagens que estavam antes distantes do público, separadas pelo narrador, ganham movimento e ação, estando vivas na narrativa/palco da história/tragédia. Essas personagens

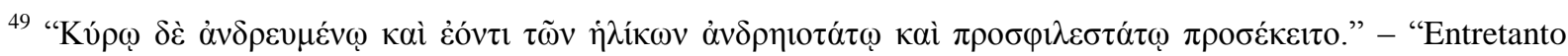
Ciro fez-se um homem e distinguia-se, entre os jovens da mesma idade, pela valentia e delicadeza" (HERÓDOTO, I, 123).

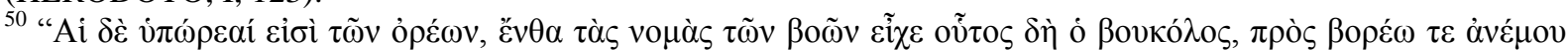

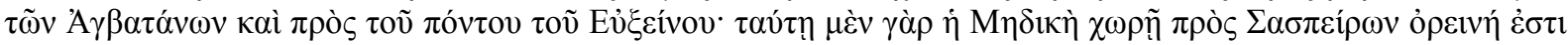

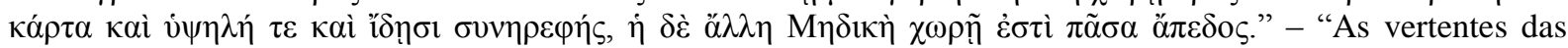
montanhas onde este boieiro apascentava o gado ficavam ao norte de Ecbátana, na direção do ponto Euxino. Nessa região, do lado dos Saspiros, a Média é muito montanhosa, elevada e coberta de florestas, enquanto o restante território é, todo ele, uma planície" (HERÓDOTO, I, 110).

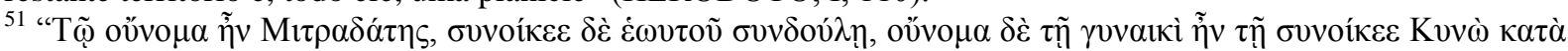

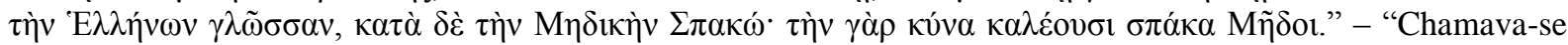
este boieiro Mitradates. Com ele vivia uma companheira de escravidão, de nome Cino em grego, Espaco na língua meda (spaca é o nome que os Medos dão à cadela)" (HERÓDOTO, I, 110).

${ }^{52}$ Não apenas a narração histórica, mas também os discursos que Heródoto intercala tendem a caracterizar as personagens que falam, definir as suas qualidades e inclinações e, também, desenvolver certos preconceitos gerais.
} 
representariam os sentimentos e os conflitos tipicamente humanos, temas que, concretamente, não diziam respeito a fatos históricos específicos. Ou seja, a técnica de citar as palavras de outros, mescladas às do próprio narrador é utilizada de forma efetiva para tornar a narrativa ainda mais dramática e as personagens na história ganham vida e falam por si mesmas, algumas vezes mesmo em diálogos:

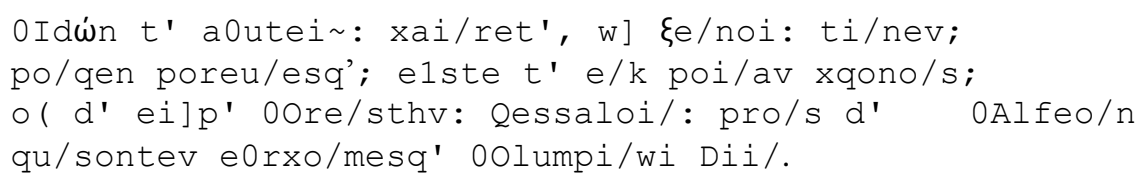

Ao ver-nos, exclamou: "Salve, estrangeiros! Quem sóis vós? De onde vindes?" Orestes respondeu: "Somos da Tessália, e vamos às margens do Alfeu, para fazer um sacrifício em honra de Júpiter Olímpico”. (EURÍPIDES, Eléctra, v. 779-782).

$\mathrm{Na}$ verdade, entendemos que toda reflexão que tenha o drama como objeto precisa se apoiar numa tríade teatral: quem vê, o que se vê, e o imaginado. Uma narrativa pressupõe, pois, o narrador, uma narração e um público - aquele que imagina a cena. E, nesse contexto, percebemos Heródoto trabalhar como um mensageiro mais uma vez. Levando ao conhecimento da audiência as ações das personagens de acordo com a sua percepção, escolha e intenção, ele muitas vezes as faz falar e agir por si mesmas, utilizando-se do discurso direto em seus relatos, como, por exemplo:

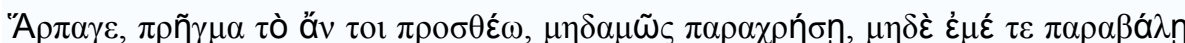

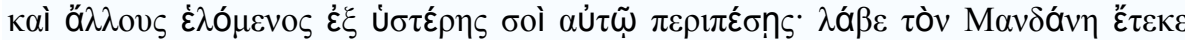

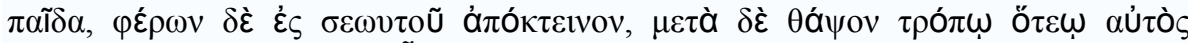

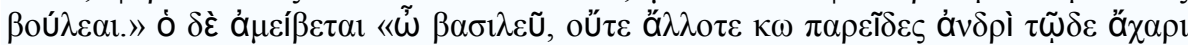

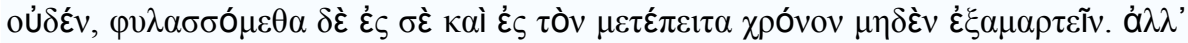

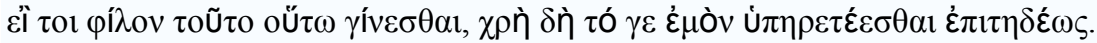

"Hárpago, não descures a missão de que te vou encarregar. Não tentes enganar-me, vês lá não vá cavar a tua ruína futura, por pores os interesses de outros à frente dos meus. Pega na criança que Mandane deu à luz, leva-a para tua casa e mata-a. Depois enterre-a como te aprouver". Hárpago retorquiu: "Meu rei e senhor, nunca, até este dia, viste, no homem que tens diante de ti, a mais pequena atitude que merecesse o teu desagrado. E vou continuar empenhado, daqui para o futuro, em não cometer contra ti uma falta que seja. Se é essa a tua vontade, é meu dever executar, com empenho, as tuas ordens". (HERÓDOTO, I, 108)

$\mathrm{Ou}:$

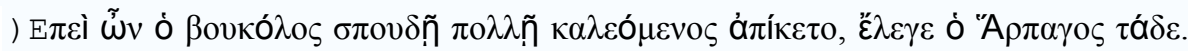

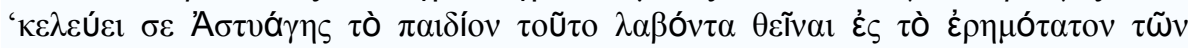

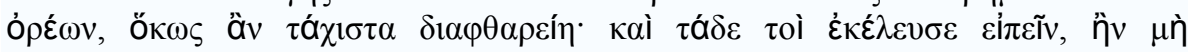

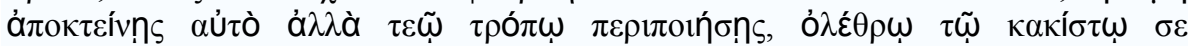

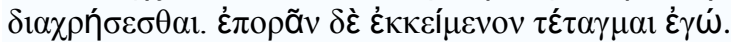


Quando o boieiro, chamado a toda pressa, chegou, Hárpago disse-lhe: “Astíages ordena que leves a criança e a abandones no lugar mais deserto da montanha, de forma que morra o mais depressa possível. Mandou-me também avisar-te de que, se em vez de a liquidares, arranjares maneira de a salvar, és tu próprio quem vai perecer da pior das mortes. A mim cabe-me a missão de verificar se ela foi exposta". (HERÓDOTO, I, 110)

Portanto, nas tragédias o mensageiro recorre à reprodução das falas através de diálogos que nos confundem ao não sabermos se são eles mera reprodução ou grande transcriação da personagem. Neste caso a estrutura narrativa é representada como se fosse composta de partes que formam o todo da dih\&ghsiv. Nesse sistema, a fala das personagens é controlada pelo mensageiro que a transmite dentro de uma lógica interna ao enredo da peça e dentro da necessidade de conhecimento do público:

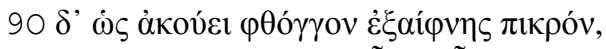

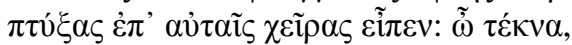

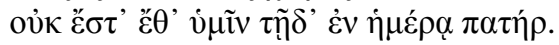

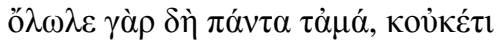

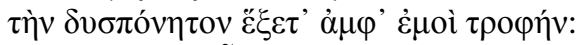

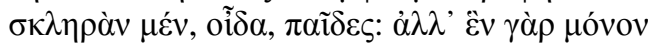

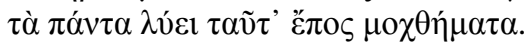

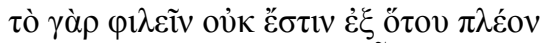

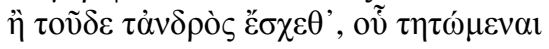

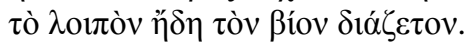

Ele, ao ouvir o repentino, sinistro sinal, estreitou-as nos braços e disse: "A partir de agora não tendes pai. Extinto está tudo que fui. O penoso trabalho de sustentar-me cessou, duro, filhinhas, eu sei. Uma palavra, uma, só deixo com paga de tantas aflições: jamais alguém vos deu o afeto que tivestes deste homem que agora vos é arrebatado por toda a vida". (SÓFOCLES, Édipo em Colono, v. 1610-1619)

Acreditamos que, a partir dessa forma narrativa, isto é, a narrativa mista, as personagens ficam interligadas no decorrer dos fatos e o público acaba por conceber um relato mais vivo, plausivo e se persuade de que esteja perante um ato verídico, independentemente do quão fantástico ele possa parecer a uma análise mais detalhada. A liberdade de transcriação das falas serve para a discussão dos assuntos considerados importantes. Vemos, portanto, a mistura da fala do mensageiro à fala das personagens, a qual atende à necessidade de ressaltar determinado fato através dos diálogos recontados: 
ou)k e) ciknou=mai Maina\&dwn o!ssoiv no\&qwn:

o!xqon d' e)pemba \v h1 e) la\&thn u9yau\&xena

ildoim' aln o) rqw=v Maina\&dwn ai) sxrourgi\&an.

Penteu, nesse instante,

Sem perceber tantas mulheres no cortejo

- ah, infeliz! - gritou: "Estás vendo, estrangeiro,

deste lugar a que acabamos de chegar

as Mênades em seus folguedos imorais?

Subamos ao rochedo e do alto de um pinheiro

dos mais frondosos, verei, com meus próprios olhos, todas as atitudes indecentes delas!'(EURÍPIDES, As Bacantes, v. 1058-1062)

Ou:

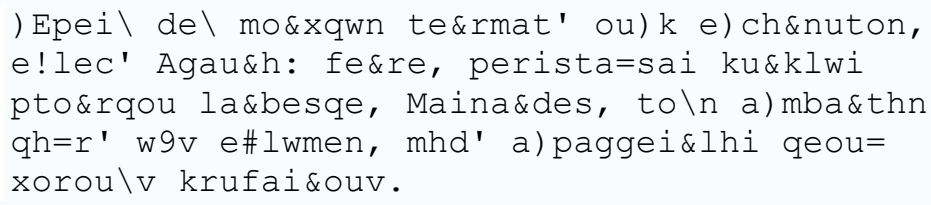

Mas, como esse esforço não dava resultados,

Agave esbravejou: "Vamos! Fazei a volta,

Mênades, minhas companheiras! Destruí

o tronco para finalmente capturarmos

a fera que está lá em cima, pois assusta-nos

a possibilidade de ela revelar

as danças e os mistérios de nosso deus!’(EURÍPIDES, As Bacantes, v. 1105-1109)

Nesse contexto, o discurso ressalta a fala alheia e as figuras contadas nas tragédias agem, ao mesmo tempo, como atores, a quem o mensageiro se refere, e como público, que assiste ao que o mensageiro narra. Estabelece-se, também, um diálogo com o espectador no qual ele assiste à duas representações: a do mensageiro enquanto mensageiro e a do mensageiro enquanto os outros que representa. Pensamos ser esta imprecisão o ponto máximo de mimese, isto é, mensageiro e personagens a quem se reporta são os mesmos porque o primeiro fala de acordo com as segundas, alcançando, assim, a legitimidade do discurso e a veracidade na narrativa:

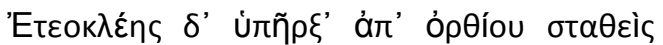

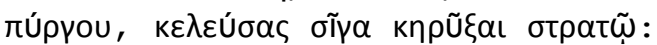
[

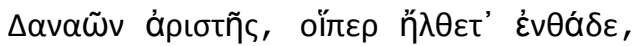

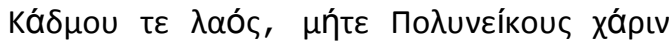

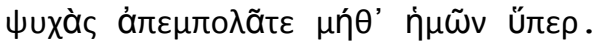

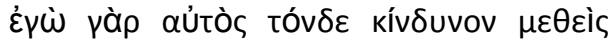

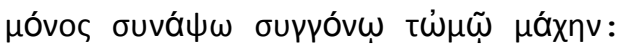

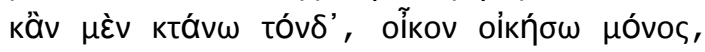

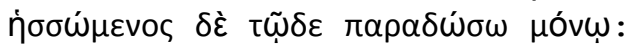

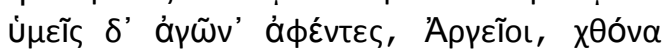




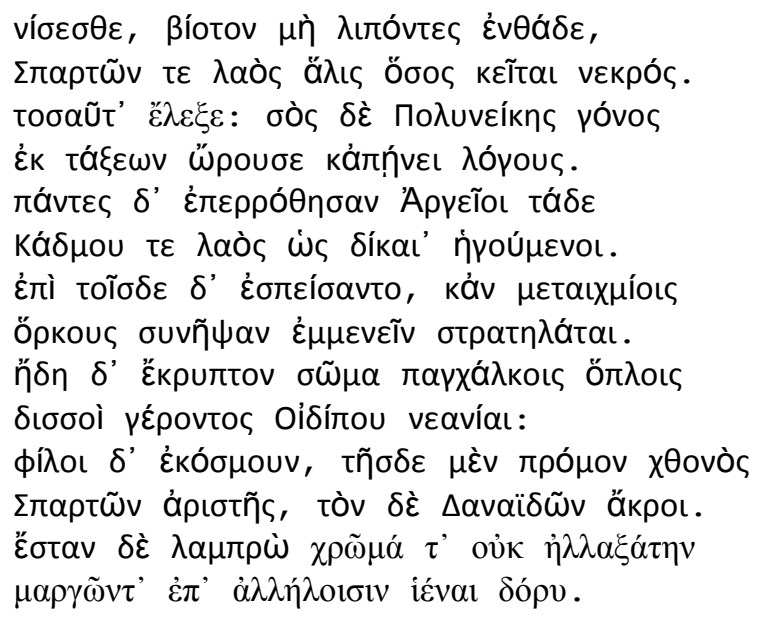

Etéocles começou, postado no alto de uma torre, a falar ao exército, depois de ordenar silêncio. Falou: Comandantes de território heleno, aristocratas dânaos, que até aqui viestes, povo de Cadmo! Por que vender vidas para beneficiar Polinice ou a mim? Eu mesmo, livrando-vos do perigo, enfrentarei só meu irmão em combate. Se eu o matar, ocuparei só eu o palácio. Se ele me vencer, o que tenho será dele. Demos por terminada a luta. Abandonai esta terra. Por que deixaríeis a vida aqui? O povo espartano que tombou aqui já basta. As palavras que proferiu foram estas. Teu filho Polinice, destacando-se das fileiras, aprovou o que foi dito. Todos os argivos e o povo de Cadmo aplaudiram ruidosos as declarações. Tiveram-nas por justas. Seguiram-se libações. Os comandantes, no espaço entre os dois exércitos, juraram cumprir o acordo. Os dois jovens filhos do velho Édipo puseram-se a cobrir o corpo com armadura de bronze. Amigos os assistiam. $\mathrm{O}$ chefe desta terra foi equipado pelos mais ilustres espartos; o outro pelos mais ilustres dânaos. Ambos luziam. No aspecto de cada um não se apagou a vontade louca de brandir a espada. (EURÍPIDES, As Fenícias, v. 12231247)

Este recurso atende, pois, à função de convencimento que o mensageiro trágico parece em geral perseguir através dos artifícios de ordem dramática, que permitem o exercício da visão do outro. ${ }^{53}$ É interessante observarmos, aqui, a dramatização, isto é, o jogo de papéis narrador/personagem - na teatralização das situações inspiradas na realidade. Este jogo de

\footnotetext{
${ }^{53} \mathrm{O}$ convencimento é também parte do papel almejado pelo historiador que, ao narrar os fatos, precisa sustentálos, sustentar a sua veracidade, a todo custo, a partir da comprovação de suas fontes. No caso de Heródoto, a história que pretende deixar às gerações futuras, salva do esquecimento, engloba, sobremaneira, e como já vimos antes, justamente "o outro".
} 
papéis estabelecido pelo mensageiro é útil com vista, principalmente, a criar uma situação empática, pois ao assumir o papel do outro vemo-lo de forma mais próxima. ${ }^{54}$

\subsection{O narrado}

Como afirmamos anteriormente, acreditamos que as razões para que Heródoto narre histórias nem sempre verdadeiras, de acordo com os fatos históricos, são as literárias e as artísticas. Pensamos essa situação pela perspectiva da recepção, para a qual a ficção, ou melhor, o impossível verossímil tem a utilidade de divertir, ainda que estejamos tratando de leituras sérias, como nas Histórias.

De fato, a palavra, quando entra em cena e/ou é narrada pelo mensageiro, desvenda ao espectador um mundo mais próximo dele que o próprio fato real, afetando sua felicidade, desgraça, ou qualquer outra emoção mais diretamente que os eventos propriamente ditos. É o discurso do mensageiro que torna possível a existência e permanência do estranho - no sentido daquele que é externo ao enredo ou ao conhecimento do público - realizando a conexão do espectador, da realidade e da consciência imediata com a subjetividade, a ficção e o discurso manipulado.

Os textos da tragédia e das Histórias dialogam com um mundo empírico e transformam a relação sujeito e objeto, observador e espetáculo em algo não mais claramente separável, o que torna a estrutura ficcional dramática marcante, considerando que ela provém da realidade. Ademais, a história ficcional é movida por indivíduos cujas falas são atos e decisões enredados por tramas verossimilhantes, de modo que o desenlace tematiza e resolve as ações das personagens. Portanto, os textos mostram as ações da criação de significados e sentidos através da sua linguagem, construindo signos pautados na identificação do imaginário dos espectadores com as personagens. Nesse contexto, são "as necessidades internas do texto que regulam a composição" e o "problema da veracidade das informações

\footnotetext{
${ }^{54}$ Todas essas situações narrativas que ora expusemos apresentam-se no texto de Heródoto, como teremos oportunidade de ver mais detalhadamente no próximo capítulo, pois é ele uma narração. Nas palavras de Brandão: "O texto histórico é também narrativo. (...) De maneira bastante clara, do ponto de vista do modo de enunciação, a história enquadra-se perfeitamente na modalidade de narrativa mista, já que comporta a fala do narrador e discursos diretos das personagens (pelo menos em relação à maioria dos historiadores antigos, incluindo o citado Heródoto), ou, no máximo, poderia representar um exemplo de narrativa simples. Seja como for, a história é narrativa. (...) Como narrativa, não haveria porque negar que a historiografia fosse, ela também, mimese, pelo menos se forem considerados os exemplos de narrativa mista em Heródoto" (BRANDÃO, 2005b, pp. 49-50).
} 
passa a ser secundário" (BRANDÃO, 2005b, p. 118), pois “verdade e mentira, portanto, não são categorias antiteticamente simples, mas dependem de contextos complexos em que importam a intenção, a situação e o destinatário" (BRANDÃO, 2005B, p. 60).

Também no que diz respeito às tragédias e ao alggelov, verdade e mentira não são categorias excludentes, mas dependem de contextos complexos em que o que conta é a intenção, a situação e o destinatário. O mensageiro deveria não só transmitir a mensagem, como, também, convencer seu recebedor e, nesse processo, não importava exatamente o que se dizia, desde que se obtivesse a atenção do interlocutor. ${ }^{55}$

O discurso podia ser, nesse sentido, inclusive enganador. Como a percepção dos eventos é, aqui, dependente exclusivamente de um indivíduo, sua subjetividade pode levá-lo não só a mal interpretar as mensagens que recebe, atribuindo-lhes outros sentidos, mas, também, a perceber os elementos explícitos ou subjacentes a outra realidade que não a sua como desfigurados em relação ao fato ocorrido e de acordo com sua intenção. Na verdade, o material narrado é uma mistura verdadeira de realismo e fantasia em proporções que nos são difíceis de discernir:

\footnotetext{
O mero fato de estarmos diante do mundo e de podermos perceber a identidade dos objetos enquanto aparecem diante de nossos olhos leva não só ao desejo de entender os processos por meio dos quais se dá a percepção e o reconhecimento, mas ainda ao desejo prazeroso da representação. $O$ discurso vale, portanto, não apenas pelo que diz, mas pelo como se diz e pelo que aparenta. (BRANDÃO, 2005b, p. 18)
}

Esta aparência tinha, pois, a intenção do convencimento. E, para convencer, no caso de Heródoto, ela precisava ser dramatizada pelo autor e por aquele que falava através dele, oferecendo-se como objeto de visão para os outros. Semelhantemente ao que ora expusemos, Heródoto, no Livro III, por exemplo, narra, na voz das personagens envolvidas, que, após revolta e intriga armada por dois irmãos magos para apoderarem-se do trono, a personagem do mensageiro surge acrescentando ao episódio informações fundamentais e verdadeiras para que o rei persa Cambises se convencesse de ter Prexaspes executado sua ordem de matar seu irmão Esmérdis:

\footnotetext{
55 Antônio Candido et al diz que a verdade, relativa a obras de arte ou ficção, possui significados diversos: "Designa com frequência qualquer coisa como a genuidade, sinceridade ou autenticidade (termos que em geral visam à atitude subjetiva do autor); ou a verossimilhança, isto é, na expressão de Aristóteles, não a adequação àquilo que aconteceu, mas àquilo que poderia ter acontecido; ou a coerência interna no que tange ao mundo imaginário das personagens e situações miméticas; ou mesmo a visão profunda - de ordem filosófica, psicológica ou sociológica - da realidade” (1976, p. 18).
} 


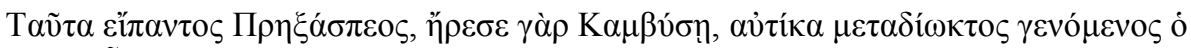

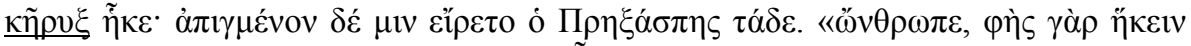

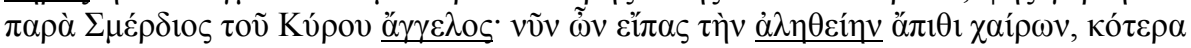

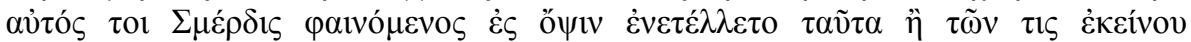

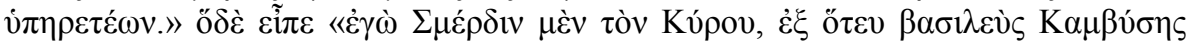

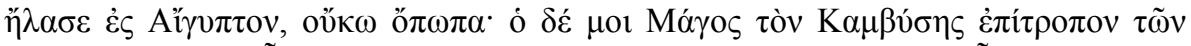

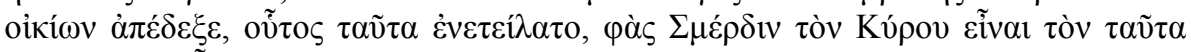

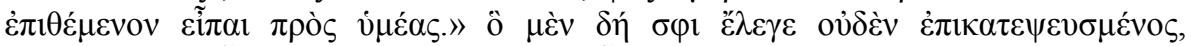

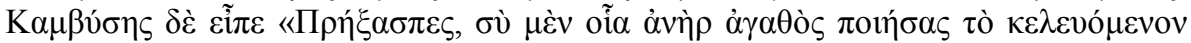

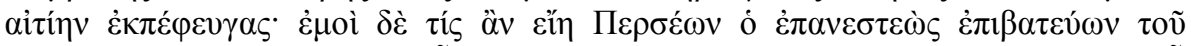

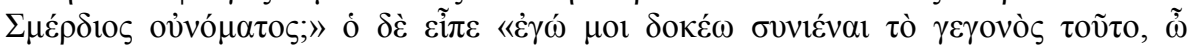

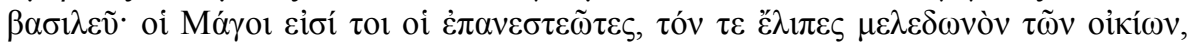

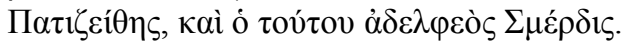

Estas palavras de Prexaspes mereceram a aprovação de Cambises; e logo alguém foi no encalço do arauto e o fez voltar. Quando chegou, Prexaspes interrogou-o: “Ouve lá, amigo, tu que dizes vir da parte de Esmérdis, filho de Ciro, trata de nos dizeres a verdade e podes ir embora em paz; foi Esmérdis em pessoa que apareceu a encarregar-te desta missão ou alguém ao seu serviço?" "Pelo que me toca respondeu o arauto - "Esmérdis, o filho de Ciro, desde o dia em que o rei Cambises partiu para o Egipto, nunca mais o voltei a ver". Foi o mago, a quem Cambises entregou a guarda do palácio, que me deu estas ordens, alegando que era Esmérdis, filho de Ciro, quem mandava transmitir-vos esta mensagem". Perante estas palavras do arauto, que correspondiam à verdade, Cambises comentou: "Prexaspes, como pessoa de bem cumpriste as minhas ordens e não te cabe nenhuma culpa. Mas quem pode ser o persa que se revoltou contra mim sob a identidade de Esmérdis?" Ao que Prexaspes contrapôs: "Julgo que sei o que se passou, meu senhor. Foram os magos que se revoltaram, aquele que deixastes de guarda à tua casa, e o irmão, Esmérdis”. (III, 63. Grifo nosso)

Percebemos, então, que nas Histórias temos as histórias narradas - o narrado - como um dado de consequências bem maiores que o da mera representação da alteridade ou da verdade, enquanto simples contraponto da mentira. A própria identidade do texto revela-se flutuante, isto é, aparece sem definição no que seria a fronteira entre o fato histórico e a ficção. O fato histórico, ao ser "ficcionado", não elimina sua possibilidade de ser a 01 h/qeia, bem como a ficção, ao se tornar história na narrativa do mensageiro/historiador Heródoto, não perde a capacidade de ser um yeûdov semelhante à verdade. ${ }^{56} \mathrm{O}$ texto, então, assume formas variadas, contando o mundo de uma forma efetiva e a partir de um estatuto próprio, pois a narrativa, na verdade, tem duas naturezas a um só tempo, provocando a quebra de limites entre realidade e ficção, deixando de ser única na sua representação para ser várias na fala do mensageiro recebida pelo seu interlocutor. Da mesma maneira, na tragédia, o mensageiro que transmite a história que se conta, ainda que com omissões, pretendia convencer e narrar às personagens em palco e ao público os fatos de uma guerra:

'A $\tau 0 \sigma \sigma \alpha$

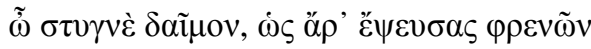

\footnotetext{
${ }^{56}$ Sobre o contraponto entre alétheia e pseûdos, cf. BRANDÃO, 2005a.
} 


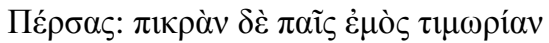

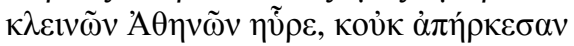

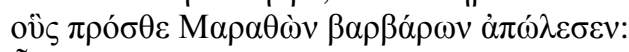

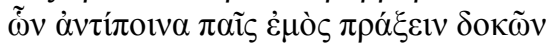

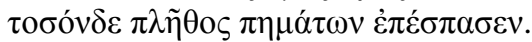

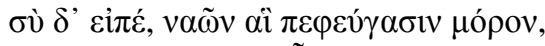

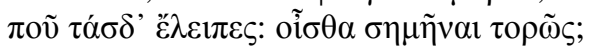
'А $\gamma \gamma \varepsilon \lambda \circ \varsigma^{\circ}$

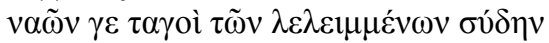

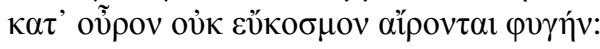

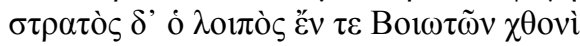

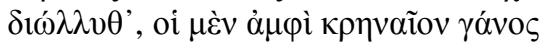

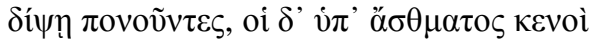

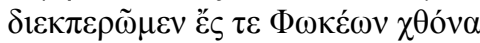

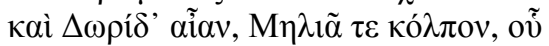

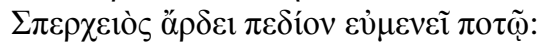

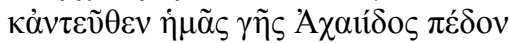

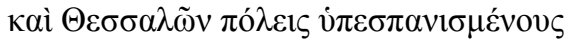

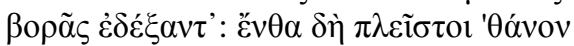

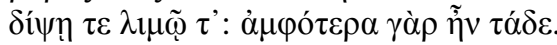

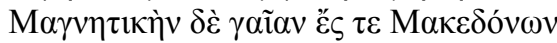

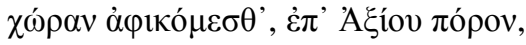

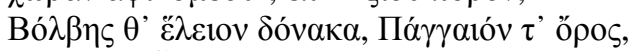

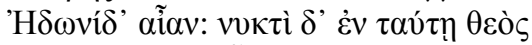

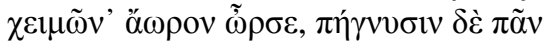

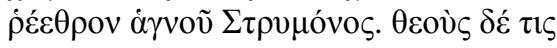

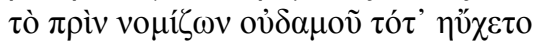

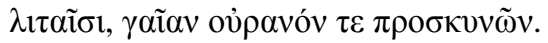

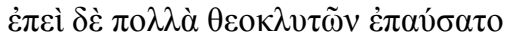

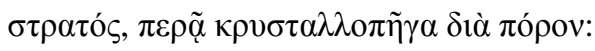

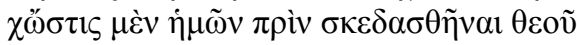

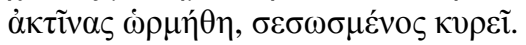

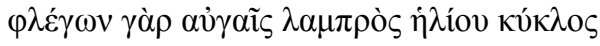

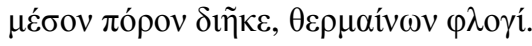

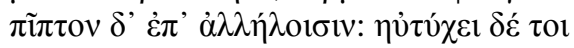

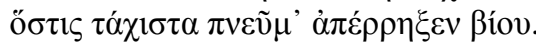

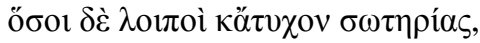

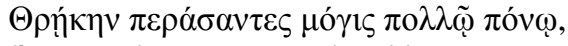

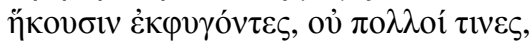

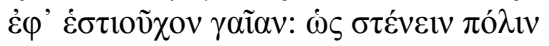

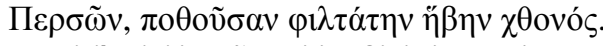

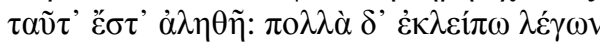

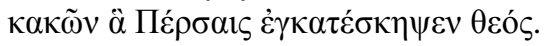

Xopós

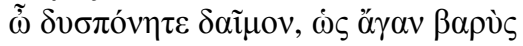

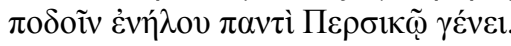

Atossa

Sorte inimiga. Quão bem ludibriaste os persas. Quão caro a meu filho custa o castigo de Atenas. Não bastavam já tantos bárbaros tombados em Maratona. Era ainda preciso que ele, na esperança de vingá-los, atraísse sobre nós esse dilúvio de desastres. Mas saberás por ventura para onde se retiraram os navios salvos da destruição?

Mensageiro

Os capitães de navios restantes fugiram em desordem à mercê dos ventos. Das tropas de terra, uma parte, devorada pela sede, pereceu na Beócia; os outros, fugindo sem tomar fôlego, atravessaram a Fócida, a Dórida e os países vizinhos do golfo Melíaco, as regiões regadas pelas salutares águas de Sperchius. De lá, desprovidos de víveres, atravessamos primeiro a Acaia e a Tessália, onde a maior parte morreu de fome e de sede - pois ambos igualmente nos perseguiam. A seguir, a Magnésia, a 
Macedônia, onde passamos o Áxio, os pântanos de Bobes, o monte Pangeu e a Hedônia. Aí, permitiram os céus que uma geada extraordinária gelasse, à noite, as águas límpidas do Estrimom. A tão inesperada ventura, até os mais incrédulos, forçados a reconhecer a intervenção dos deuses, se prostaram diante do céu e da terra. Após longa e fervorosa prece, o exército avançou pelo gelo. As tropas que conseguiram passar antes do amanhecer, foram salvos; mas quando o luminoso e flamejante disco derreteu o gelo, os soldados precipitaram-se no rio. Felizes os que logo se afogaram. Os poucos que conseguiram escapar ao perigo, após percorrerem com grande dificuldade a Trácia, regressaram, em fuga, aos lares paternos. Assim, gemente, a Pérsia, por muito tempo, lamentará a flor de seu império. Essa é a verdade, embora em meu relato haja omitido várias das circunstâncias da catástrofe com que nos trucidaram os deuses.

Coro

Incrível destino. Que funesto é teu peso sobre a raça inteira dos persas, hoje esmagados por teus golpes. (ÉSQUILO, Os Persas, v. 472-516. Grifo nosso)

Com efeito, esses deslocamentos entre fato e ficção se dão, principalmente, porque o mensageiro trágico, bem como Heródoto, utiliza-se da fala de outros, elaborando o narrado como um discurso que pode representar $y e u=d o v$ próximos a situações fidedignas. $\mathrm{Na}$ verdade, nós somos levados a pensar de uma maneira maniqueísta o bem e o mal, a verdade e a mentira e, consequentemente, uma das opções sempre seria fator excludente da outra. Mas uma não- verdade não significa necessariamente uma mentira.

É preciso que lembremos que, quanto ao historiador, nos processos de elucubrações históricas o indivíduo não é meramente uma testemunha ocular ou alguém impassível diante dos fatos. Ele é, antes de tudo, um ser carregado de subjetividade e que realiza escolhas do que narrar, de quando narrar, para quem narrar e, o mais importante para nós, de como narrar. A percepção dos eventos é completamente submetida à percepção singular de um sujeito e, por isso, afirmamos que, embora Heródoto pareça mentir sobre muitas coisas, criando encontros, falas e cenários dotados de ye\&udea, o narrado nas Histórias quer seduzir, ser exato, convencer, apresentar coesão, emocionar e demonstrar acordo com pesquisas as mais minuciosas, garantindo ao seu autor a possibilidade de dar existência aos eventos através de uma narração repleta de artifícios de dramatização que comunicam a verossimilhança do ocorrida por mentiras bem contadas.

O que buscamos mostrar é o fato de que os conceitos forjados pelo historiador/narrador são sempre dependentes de tempos e de situações históricas e estão emaranhados em textos e contextos. Dessa forma, há certo grau de mobilidade pelo qual um mesmo referente linguístico pode engendrar diferentes significações. As representações podem se tornar específicas pela leitura mental e emocional daquilo que o historiador torna inteligível para o público, independentemente de ser o narrado autêntico ou ornado por yeu=dov. 
Para o mensageiro, e aqui não nos referimos somente à personagem trágica, mas a todo aquele que comunica, dá notícia ou relata algo impossível de se dar diante de nossos próprios olhos, a linguagem é uma ferramenta utilizada para descrever o mundo, sendo, também, uma parte do mundo e, assim, o narrado é matéria dada aos métodos de interpretação e representação, e a verdade, construída pela linguagem em dois movimentos - quando do momento da escrita e quando do momento da leitura - perde o status de necessária: "Heródoto coloca-se no domínio do lógos e do légein, convidando o auditório/leitor a estabelecer seu julgamento: mesmo que o testemunho oral ou aural confirme sua hipótese, a alétheia não deve ser o objetivo último do historiador" (MORAIS, 2004, p. 47).

O objetivo é o de contar histórias que possam encantar e povoar o mundo real narrado do que havia de fantástico para o público. As verdades reveladas habitavam um mundo recriado, isto é, revelavam o significado dos eventos sem, contudo, cometer o erro de buscar defini-los. A intenção clara era a de conduzir o espectador, através de aspectos esquemáticos e de escolhas cuidadosas das palavras, a experimentar as conotações peculiares dos momentos visuais, táteis, auditivos, aparências físicas e processos mentais das personagens e objetos:

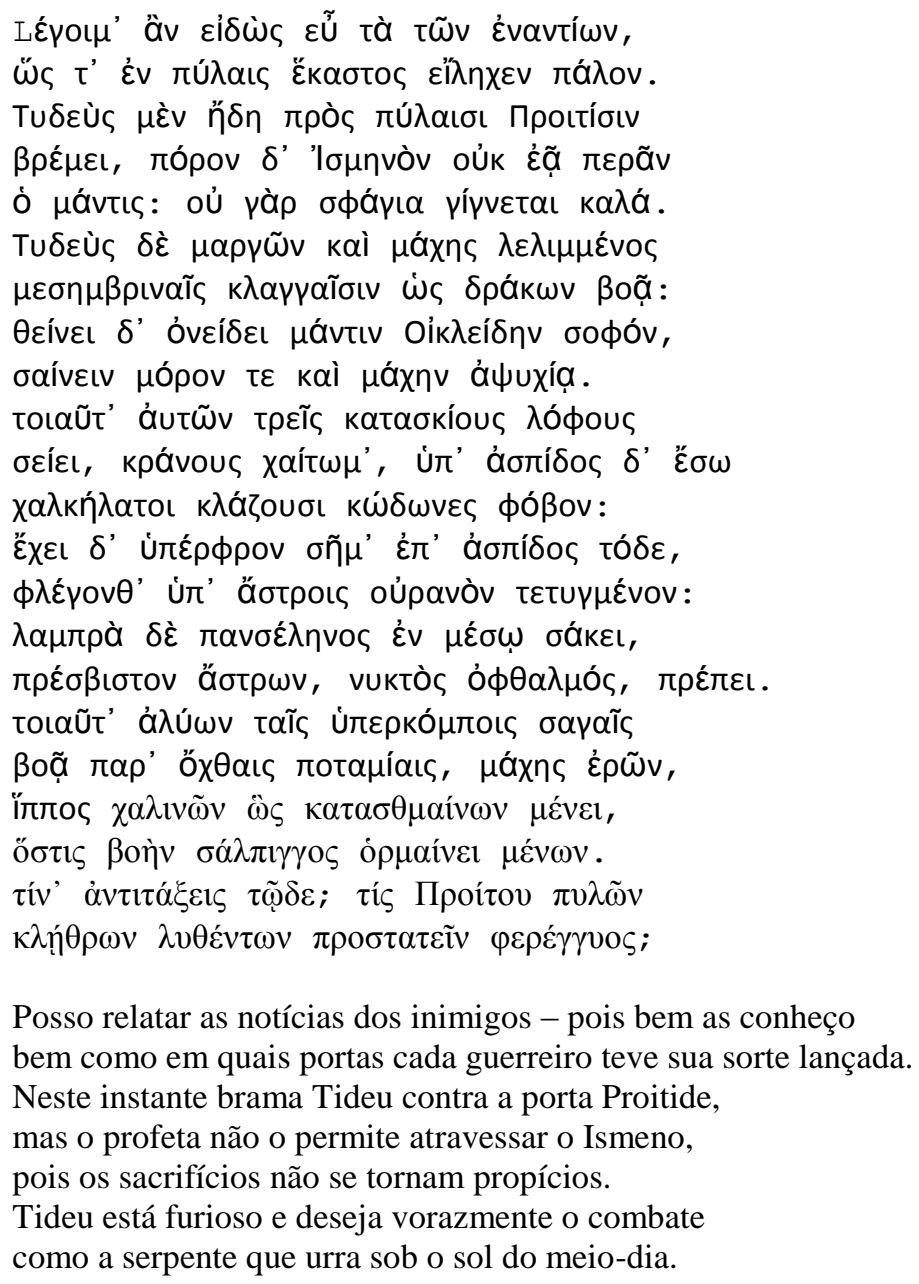


Ultraja o sábio profeta filho de Ecleu dizendo:

"o pusilânime bajula o destino e o combate".

Vitupérios à parte, agita três penachos sombreados,

juba de seu casco, e em seu escudo,

os sinos feitos de bronze anunciam o terror.

Em sua superfície tem um orgulhoso emblema talhado:

um céu com estrelas resplandecentes

e um plenilúnio brilhante, o mais respeitável dos astros,

olho da noite, em seu centro fulgura. (ÉSQUILO, Sete contra Tebas, v. 375-390)

O narrado deveria ser, pois, doado ao público através da transfiguração da realidade dos momentos selecionados para a narração, de forma a tornar-se algo significativo para ele, para além dele e, principalmente, para além do factual empírico, como meio de criar a obra narrativa. Assim, independentemente dos elementos fictícios acrescentados aos eventos históricos, temos uma história que convence, dá ao conhecimento aquilo que é externo ao espectador e deixa uma mensagem fluida de assuntos que consideramos, sob a ótica contemporânea, de abordagem séria, isto é, assuntos que pressupõem intenção de verdade.

Por fim, quanto a Heródoto e sua a) ggeli\&a, o leitor parece-nos convidado a um movimento paradoxal de conhecer a realidade histórica e permanecer na camada da fantasia, da imaginação e/ou do maravilhoso que a encobrem. Para o público do século V, isto é, um público na maioria iletrado, mas não ignorante, a intenção ficcional era visível e clara, mesmo quando não objetivada. À obra Histórias foi possível dar uma energia expressiva através da linguagem, particularizando, concretizando, individualizando e construindo enredos e cenários mais que simplesmente reais ou fictícios: enredos e cenários sedutores e repletos de conhecimentos verossimilhantes. Isto é, um conteúdo mais próximo daquilo que é o próprio homem, repleto de subjetividade e criação. 
"É a experiência de que a arte de narrar está em vias de extinção.

São cada vez mais raras as pessoas que sabem narrar devidamente. (...) É como se estivéssemos privados de uma faculdade que nos parecia segura e inalienável: a faculdade de intercambiar experiências”.

BENJAMIN, O Narrador

\section{HISTÓRIAS TRAGICAMENTE NARRADAS E DRAMATIZADAS}

4.1 No espírito trágico: o discurso de Sólon e o lógos de Candaules

Neste capítulo trataremos de realizar uma seleção de histórias fantásticas da obra herodotiana e, a partir delas, mostraremos como determinadas imagens construídas pelas palavras na mente dos leitores/espectadores/ouvintes falam por si mesmas de forma bastante semelhante ao que ocorre nas cenas teatrais e nas falas dos mensageiros trágicos. 
Heródoto ama contar boas histórias. Como bom pesquisador, o autor recolhe pequenos lógoi $^{57}$ que eram narrados desde tempos imemoriais, dando a eles uma interpretação pessoal, expressando suas convicções em relação às histórias, visando a dar coerência à massa de informações que recolhia.

Nesse contexto surge "o maravilhoso" (qw ma), pois acreditamos que ele sirva como elo que torna a narrativa compreensível, uma vez que o que Heródoto procura é explicar. Entenderemos, aqui, o espaço do maravilhoso como o de um mundo (trans)figurado, (sub)vertido, o que permite uma quase arbitrariedade na intriga. A questão da verossimilhança no maravilhoso torna-se peculiar, já que neste gênero os fenômenos, apesar de (im)possíveis, não deixam de ser críveis.

$\mathrm{O}$ universo do maravilhoso seria, então, o da inverosimilhança verossímil. Na aproximação de Heródoto do mensageiro trágico percebemos certa relação entre este maravilhoso e o sensacionalismo. Este, como uma espécie de balança, oscila em determinado momento para a punição e, em outro, para a transgressão. A narrativa herodotiana e a narrativa do alggelov enveredam pelo caminho sensacionalista no momento em que chamam a atenção para si por meio destes dois fatores: a punição e a transgressão. ${ }^{58}$ Ao "sensacionalizar" um fato, o narrador coloca sobre ele uma espécie de lupa que o amplia e/ou amplia nele aquilo que lhe convém de mais impressionante, ainda que, de fato, não fosse o objeto ampliado o que houvesse de mais sensacional. Aqueles dois elementos sensacionalistas funcionam, então, como ferramenta para aumentar a atenção e a tensão do público, implicando numa opção de forma narrativa a partir de uma linguagem específica e particularizada - isto é, sem distanciamento por parte daquele que narra em relação ao seu objeto - e do enfoque em atos que poderiam ser considerados com escandalosos, chocantes ou exóticos.

$\mathrm{Na}$ verdade, o leitor/ouvinte/espectador entra no mundo sensacionalista quando tem, em si mesmo, provocadas as sensações intensas de admiração e entusiasmo associadas aos

\footnotetext{
57 A obra herodotiana é um complexo arranjo de numerosos relatos mais ou menos independentes, tradicionalmente chamados de lógoi. Os pontos em comum, de estrutura e conteúdo, entre estes pequenos lógoi das Histórias e a tragédia são de tal forma evidentes que Immerwahr os classifica de "lógoi dramáticos" (1966, p. 69). Este autor reconhece que a análise dos fatos e a sintetização de alguns tópicos essenciais da obra herodotiana são marcados pela tragédia e pelos conceitos aristotélicos que a definem. Immerwahr ressalta, ainda, que a influência do trágico na prosa das Histórias pode ser verificada tanto na forma - presença de pequenos episódios encadeados por esquemas dramáticos - quanto em questões e temáticas abordadas - falibilidade e vicissitude da condição humana, mutabilidade da fortuna e castigo pela desmedida, por exemplo. Certo ar de sensacionalismo também nos parece fazer parte das temáticas uma vez que consideramos que Heródoto, bem como o mensageiro trágico, é movido pela narração do que consideramos histórias pitorescas, exóticas e/ou fantásticas.

${ }^{58}$ Veremos as questões da punição e da transgressão ao longo deste capítulo.
} 
sentimentos de punição e transgressão em relação às cenas que lhes são apresentadas, a partir do momento em que há a exploração dos acontecimentos de forma que os mesmo sejam capazes de emocionar ou escandalizar.

Nesse contexto, afirmamos que nosso autor percebe que, através do maravilhar-se, lhe seria possível criar toda uma compreensão de mundos, a princípio, bastante diferentes. Simultaneamente, ao maravilhar-se, o que escuta a história, encantado, aprende e conhece a coisa narrada, pois vê a coisa ou o fato à distância e julga. Por fim, é capaz, também, de conhecer o próprio narrador e sua perícia. ${ }^{59}$ De fato, diante da maravilha, não se pode ficar indiferente, e Heródoto não fica:

\begin{abstract}
O maravilhoso na obra herodotiana é uma narrativa de compreensão de um mundo que, embora estivesse fora de seu alcance de tudo ver, não deixa de provocar-lhe o desejo de explicar. Os thômata, com toda sua diversidade, mostram como Heródoto, embora não conheça tudo que descreve em suas Histórias, não se exime de tentar compreender. (MORAIS, 2004, p. 172)
\end{abstract}

Ao mergulhar no universo maravilhoso das histórias que narra, Heródoto provoca a possibilidade do espectador experimentar, através do olhar, da voz e do corpo de suas personagens, a própria história, gerando diálogo com a obra. O maravilhoso parece ser em Heródoto um dos motivos pelos quais as suas narrativas possuem caráter infindável. $\mathrm{O}$ historiador prossegue narrando enquanto o maravilhoso permite, ou seja, enquanto as suas viagens prosseguiram, pois muitas das maravilhas são parte do conhecimento adquirido em suas viagens (MORAIS, 2004). O maravilhoso adquire um caráter de "notícia" a partir daquilo que tem de sensacional, isto é, Heródoto, mensageiro de notícias das terras nãogregas, narra aquilo que é de interesse do público grego.

Sem dúvida, um dos episódios mais célebres das Histórias, considerado pelos comentadores uma das obras primas dos chamados "lógoi dramáticos", é aquele que, entre os capítulos 8 e 12 do Livro I, encena as intrigas palacianas que levaram à deposição de

\footnotetext{
59 Aristóteles na Poética afirma: “A tendência para a imitação é instintiva no homem, desde a infância. Neste ponto distingue-se de todos os outros seres, por sua aptidão muito desenvolvida para a imitação. Pela imitação adquire seus primeiros conhecimentos, por ela todos experimentam prazer. A prova nos é visivelmente fornecida pelos fatos: objetos reais que não conseguimos olhar sem custo, contemplamo-los com satisfação em suas imagens mais exatas; é o caso dos mais repugnantes animais ferozes e dos cadáveres. A causa é que a aquisição de um conhecimento arrebata não só o filósofo, mas todos os seres humanos, mesmo que não saboreiem durante muito tempo essa satisfação. Sentem prazer em olhar essas imagens, cuja a vista os instrui e os induz a discorrer sobre cada uma e a discernir aí fulano ou sicrano. Se acontece alguém não ter visto ainda original, não é a imitação que produz o prazer, mas a perfeita execução, ou a cor ou outra causa do mesmo gênero" (1448b10-19).
} 
Candaules e à ascensão de Giges ao trono da Lídia. ${ }^{60}$ Nosso foco se concentrará, aqui, na morte, como forma de enfatizarmos o processo de dramatização do autor. Porém, antes de discorremos sobre isto, a propósito do lógos de Candaules nas Histórias, perpassaremos pelo diálogo entre o rei Creso e o ateniense Sólon, o qual nos traz a emblemática ideia de que a maior felicidade de um homem é ter uma vida sem grande riqueza ou pobreza, mas, sobretudo estável, equilibrada.

Visto que os homens agem condicionados pelos fatores que fazem deles membros de uma comunidade, as tradições acabam por ditar e enformar os atos de morrer ou de matar. Parece-nos, nessa perspectiva, que, para Heródoto, a morte significa muito mais do que a última etapa da vida, pela importância decisiva que ele atribui a ela enquanto elemento aferidor da felicidade. Ele tem o cuidado de retratar a morte no seu sentido moral, enquanto reflexo dos valores do homem - e isto é posto em relevo nas lições fundamentais da narrativa do discurso de Sólon, em que se apresenta o perigo da autoconfiança do indivíduo no seu conhecimento da vida, tantas vezes enganoso.

O lógos de Creso domina o primeiro quarto do Livro I das Histórias e sua inclusão justifica-se por ser ele o primeiro a agredir os gregos na Ásia e por ser o monarca de um grande império bárbaro, o Reino da Lídia. Ele tanto dominou os gregos da Jônia, como fez aliança com os gregos de Esparta:

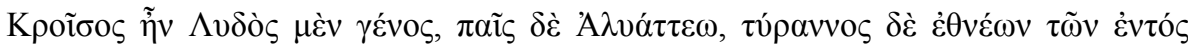

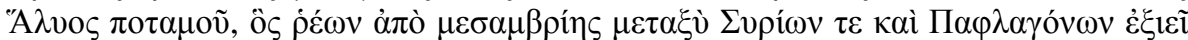

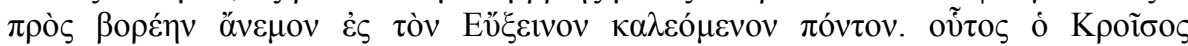

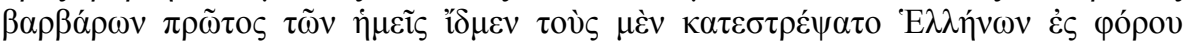

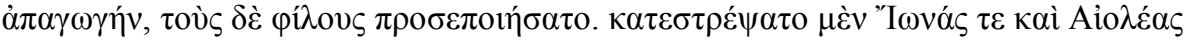

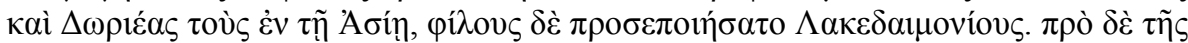

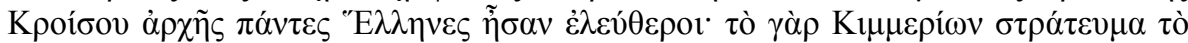

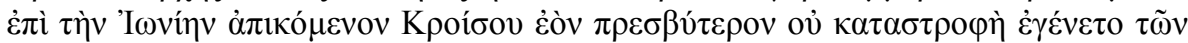

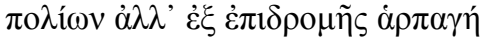

Creso era de raça lídia, filho de Aliates, soberano dos povos situados para cá do rio Hális que, correndo do sul entre os Sírios e Paflagónios, deságua na direção do vento norte, no mar chamado Euxino. Este Creso foi o primeiro dos Bárbaros, de que temos conhecimento, a submeter alguns Helenos a pagamento de tributo e a fazer de outros seus amigos. Submeteu os Iónios, os Eólios e os Dórios que habitam na Ásia e fez seus amigos os Lacedemónios. Antes do reinado de Creso, todos os Gregos eram livres. De facto a expedição dos Cimérios que atingiu a Iónia, embora mais antiga do que Creso, não originou sujeição das cidades, mas pilhagem resultante de incursão. (HERÓDOTO, I, 6)

\footnotetext{
${ }^{60}$ Myres (1952) reconhece o lógos lídio como uma espécie de cenário em prosa para a trágica tomada de Sardes. Sob esta perspectiva, as cenas iniciais de Giges e Candaules, que marcam a ascensão dos Mérmnadas, constituiriam uma espécie de prólogo.
} 
Na verdade, a entrevista entre Creso e Sólon, que ocorre entre os capítulos 29 e 33 do Livro I, é uma história de ficção que caracteriza Creso no auge do poder. ${ }^{61}$ Dizemos de ficção porque a narrativa é anacrônica, pois Sólon, nascido em cerca de 640 a.C., teria apresentado suas leis a Atenas em 594-593 a.C. Portanto, se retornasse para lá, como diz o texto, apenas dez anos depois, isto se daria em 584-583 a.C., muito antes de Creso ascender ao trono de Sardes em c. 560 a.C. e mais distante ainda do clímax de seu poder. Desta forma, parece-nos que esta história de ficção tem valor para a obra de Heródoto por seu caráter simbólico e maravilhoso, abordando elementos do imaginário que as duas personagens encerram em si. ${ }^{62}$

Não deixamos, porém, de acreditar que, para Heródoto, a verdade - que preferimos tratar por verossimilhança - do desenvolvimento histórico reside na mistura ou inserção das atitudes e atos possíveis de acontecer com as personagens envolvidas, sendo irrelevante se os dados cronológicos tornam improvável essa concretização. De fato, nada melhor que este encontro entre Sólon e Creso para transpor para a estrutura e desenvolvimento das Histórias uma imagem apropriada e poderosa do que podemos chamar da dramatização de dois indivíduos históricos. O discurso fictício guarda, aqui, uma relação de semelhança com o verdadeiro, permitindo aos ouvintes o reconhecimento de marcas de veracidade. Não queremos, porém, ater-nos à contraposição entre ficção e realidade, mas apenas ressaltar que o encontro em questão é convincente porque se utiliza de estratégias que o fazem semelhante a fatos autênticos. ${ }^{63}$

O trecho introduz, na pessoa de Sólon, a voz da razão que Creso, no auge de seu poder, como já vimos, precisa ouvir. Entretanto, o rei bárbaro não o fará e é exatamente este "não ouvir" que dará à narrativa seu rumo trágico. Durante todo o relato, Heródoto se

\footnotetext{
${ }^{61}$ François Hartog (2003, p. 39) argumenta que a entrevista do sábio de Atenas com o déspota da Lídia pode ser considerada um mythos inserido no lógos de Creso. Tal consideração apóia-se na revisão do conceito de mito feita por Claude Calame a partir da teoria da enunciação e da recepção (1996, p. 46-55). Calame propõe o entendimento do mito como manifestação simbólica, "resultado material de um processo de significação", gerador de "efeitos de sentido" por meio da narração e ressalta a interdependência dessa construção com o momento de enunciação.

${ }^{62}$ François Hartog afirma que: "De um modo geral, os gregos têm um estoque de personagens disponíveis e prontas para atuar em todas as situações: presentes como operadores de inteligibilidade, servem para classificar e ordenar os fenômenos, ajudando a pensar o mundo, o que os torna uma espécie de instrumentos de pensamento, uma sorte de ferramentas lógicas" (1999, p. 241). Por isso, no episódio da visita de Sólon à corte lídia, assiste-se ao encontro de duas figuras históricas que convivem na entrevista narrada pelo historiador como "operadores de inteligibilidade". Em Heródoto, o sábio e o monarca afiguram-se como paradigmas antitéticos: Sólon de Atenas, sofós, como é referido no texto, e principalmente conforme dito na tradição literária grega é representante do ideal da temperança e da justa medida; Creso, monárquico, bárbaro e representante de uma alteridade, é a imagem da cupidez e da desmedida e, entre estas duas personagens, têm-se confrontados os valores da u3briv e da sofrosu/nh (RIBEIRO, p. 66).

${ }^{63}$ Acreditamos e partimos do pressuposto de que uma condição indispensável para a comunicação é que o emissor e o receptor aceitem que são semelhantes e partilhem de um contexto de semelhança. Esta semelhança é o que estabelecerá os parâmetros de avaliação da mensagem. Portanto, como veremos mais adiante, inclusive no tópico seguinte ao tratarmos do lógos de Cleómenes, a semelhança será condição da verossimilhança.
} 
preocupa em mostrar como os fatos se desencadeiam de forma a se compreender seu final. $\mathrm{O}$ debate entre Creso e Sólon é articulado em torno de uma questão fundamental: qual o mais feliz dos homens? Certamente, o rei lídio julgava que a exposição de suas riquezas ao ateniense causar-lhe-ía forte impressão, preparando uma resposta favorável à sua indagação. Mas os critérios de Sólon para responder à questão seguem uma análise rigorosa de linguagem e do bom senso grego. Creso perguntou-lhe sobre quem era mais feliz usando o termo o0lbiw/taton, o mais próspero, superlativo de ollbioj, que significa rico e poderoso de uma forma estável e constante:

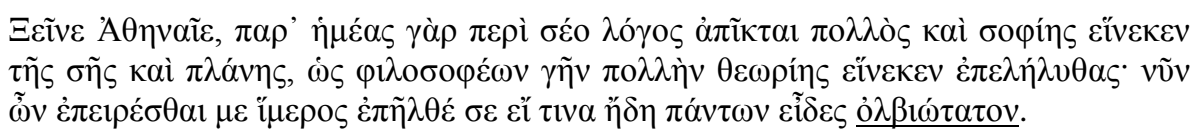

"Hóspede ateniense, até nós chegaram muitas vezes relatos a teu respeito, por causa da tua sabedoria e das tuas viagens, como, por amor à sabedoria, tens percorrido toda a terra, levado pela curiosidade. Veio-me agora o desejo de te perguntar se já viste alguém que fosse o mais feliz dos homens". (HERÓDOTO, I, 30. Grifo nosso)

Assim, a resposta de Sólon não fala do afortunado momentaneamente, mas do que possui felicidade estável. Na encenação de semelhante quadro coube a Sólon o papel que lhe era atribuído pela tradição, o de sábio (e0pista/menon), respondendo à pergunta colocada pelo interlocutor (e9peirwtai v), mas não correspondendo às suas expectativas de ouvir da boca de um homem tão considerado como aquele grego o reconhecimento do que julgava ser o seu motivo de orgulho, isto é, possuir o estatuto de "o mais próspero dos homens":

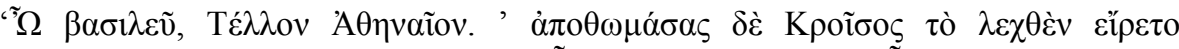

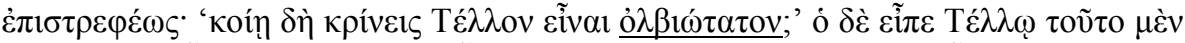

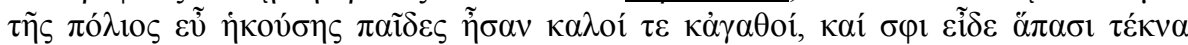

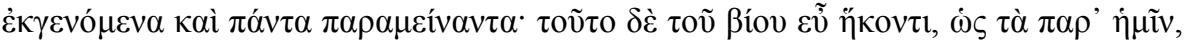

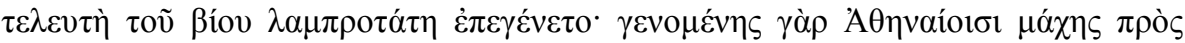

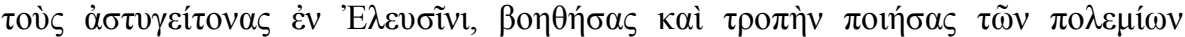

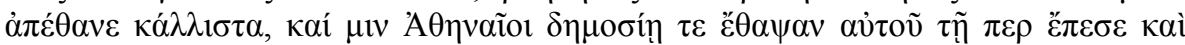

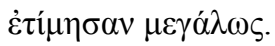

"Sim, ó rei, Telo de Atenas". Surpreendido com a resposta, Creso perguntou com interesse: "Porque julgas que Telo é o mais feliz?" E ele explicou: "Natural de uma cidade próspera, por um lado, teve filhos belos e bons e de todos eles viu nascerem filhos e todos permanecerem com vida; por outro, depois de gozar uma vida próspera, para o nosso meio, teve o mais brilhante termo da vida. Declarada a guerra pelos Atenienses contra os seus vizinhos de Elêusis, ele acorreu em auxílio, provocou a fuga dos inimigos e morreu da forma mais gloriosa. Os Atenienses sepultaram-no com exíquias públicas no próprio local em que tombou e tributaramlhe grandes honras". (HERÓDOTO, I, 30. Grifo nosso)
} 


\title{
A incompreensão de Creso para com a resposta de Sólon motiva outra questão: o que
} achava o ateniense de seu poder:

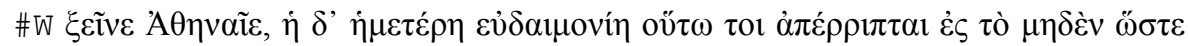

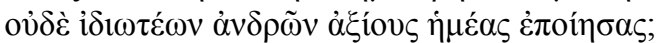

"Hóspede ateniense, e a nossa felicidade assim a lançaste na conta do nada, a ponto de nem nos equiparares a esses simples particulares?” (HERÓDOTO, I, 32)

Sólon, então, expõe a filosofia por trás de suas palavras: os deuses são ciumentos ${ }^{64} \mathrm{e}$ conturbadores e o homem é frágil. Assim, como os dias de uma vida são muitos, não se pode afirmar que um homem é feliz ( $\left.11 \_i \circ j\right)$ a não ser que tenha terminado seus dias:

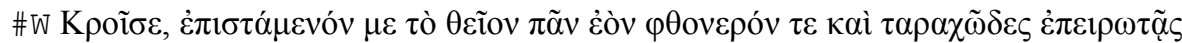

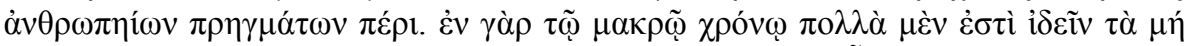

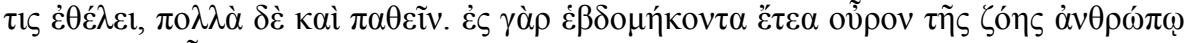

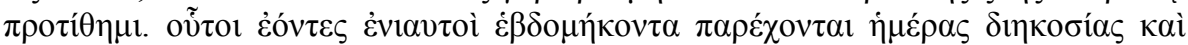

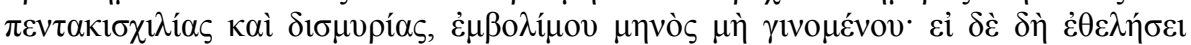

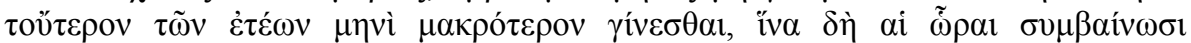

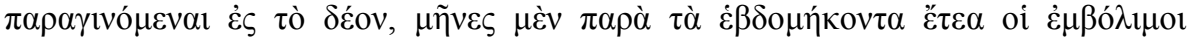

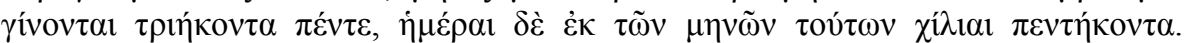

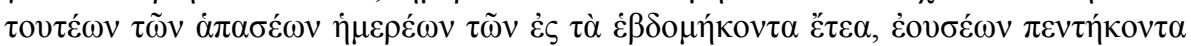

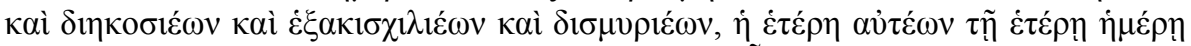

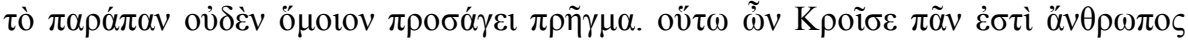

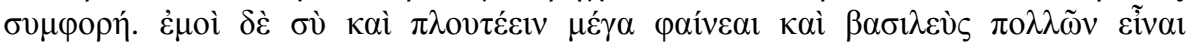

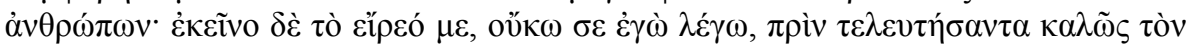

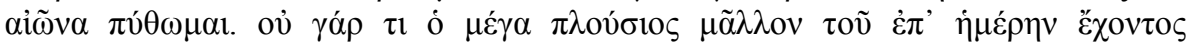

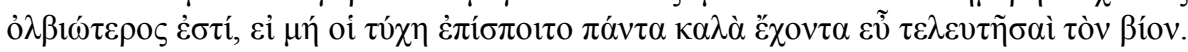

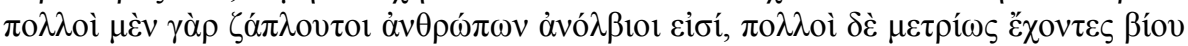

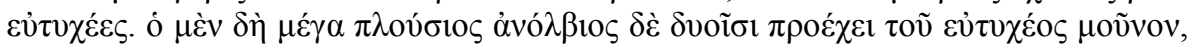

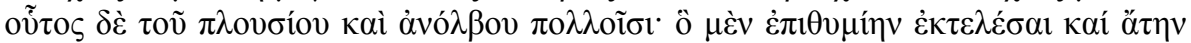

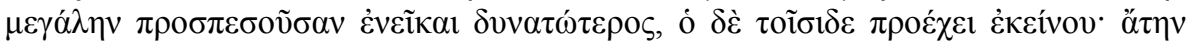

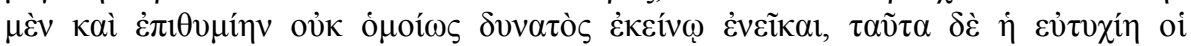

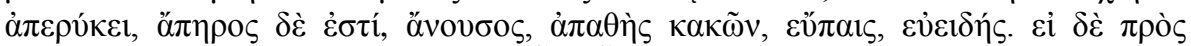

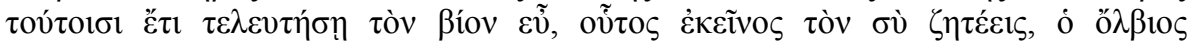

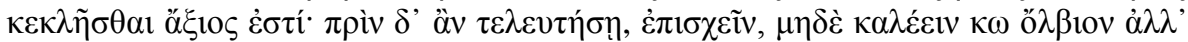

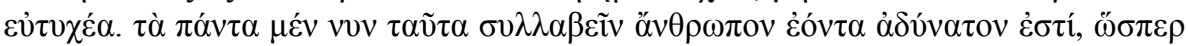

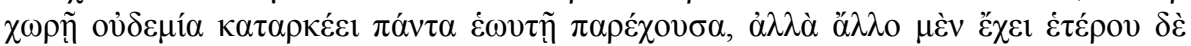

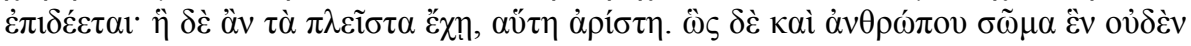

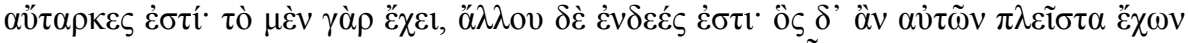

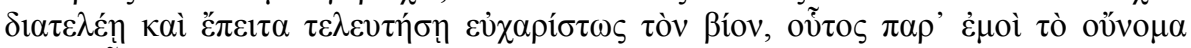

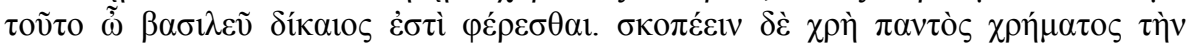

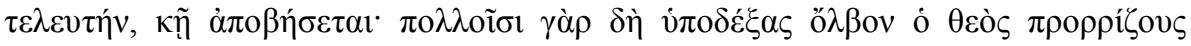

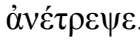

"Ó Creso, eu sei que a divindade é toda inveja e irritável, e tu interrogas-me sobre coisas humanas. Ora, no longo tempo de uma vida, há ocasião de ver e padecer muitas coisas que uma pessoa não queria. $\mathrm{Na}$ verdade eu fixo em setenta anos o limite da vida para o homem. Esses setenta períodos de um ano perfazem vinte e

\footnotetext{
${ }^{64}$ Os homens não detêm o controle total sobre suas vidas; a providência, sem motivo ou justificativa aparente, manipula os destinos, tanto das nações como dos indivíduos. Os deuses também eram invejosos e vingativos em relação aos seres humanos, pois queriam impedir que a felicidade dos homens fosse tanta quanto a sua. Afinal, se os próprios deuses possuíam desventuras, como que simples mortais poderiam ter a pretensão de serem felizes?
} 
cinco mil e duzentos dias, não incluindo o mês intercalar. Se um em cada dois anos tem de ser aumentado de um mês, para que as estações calhem no tempo devido, em setenta anos os meses intercalares são trinta e cinco e os dias derivados desses meses mil e cinqüienta. De todos estes dias necessários para os setenta anos, que perfazem vinte e seis mil duzentos e cinquenta, nenhum deles oferece acontecimentos absolutamente iguais aos outros. Sendo assim, ó Creso, o homem é todo vicissitude. Pareces-me muito rico e o rei de muitos homens, mas o que tu me perguntaste eu não te posso dizer que o sejas, antes de saber se atingiste feliz o termo da vida. É que o homem muito rico não é mais feliz do que o que tem para o dia-a-dia, se não o acompanha a sorte de terminar a vida no meio de toda a espécie de prosperidades. Muitos homens ultra-ricos são infelizes e muitos outros de modestos recursos de vida são pelo contrário afortunados. Quem é muito rico, se infeliz, apenas em duas coisas supera o afortunado, mas este supera o rico infeliz em muitas. Um tem mais recursos para satisfazer um desejo e para suportar o golpe de uma grande calamidade, mas o outro supera-o no seguinte: se não é capaz de enfrentar do mesmo modo que ele desgraças ou desejos, a boa sorte preserva-o desses males; é uma pessoa sem enfermidades, sem doenças, que não conhece desgraças, com boa descendência e belo aspecto. Se, a somar a isso, ainda terminar bem a vida, esse é quem tu procuras, o que merece ser designado feliz. Mas, antes de chegar ao fim, espera e não o chames feliz, mas afortunado". (HERÓDOTO, I, 32)

A questão da fragilidade da condição humana e a mutabilidade da fortuna compõem a fala com a qual o sábio encerra seu discurso e se despede da corte de Creso. Podemos observar a semelhança desta narrativa com a tragédia grega, através do modo semelhante como fala o coro dos velhos habitantes de Tebas em Édipo Rei:

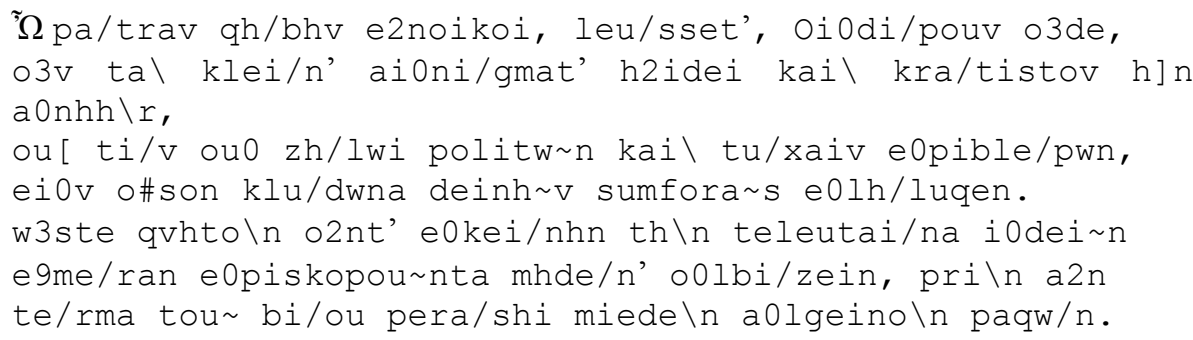

Olhai o grão-senhor, tebanos, Édipo,

decifrador do enigma insigne. Teve

o bem do Acaso - Týkhe -, e o olhar de inveja

de todos. Sofre à vaga do desastre.

Atento ao dia final, homem nenhum

Afirme: eu sou feliz!, até transpor

- sem nunca ter sofrido - o umbral da morte. (SÓFOCLES, v. 1524-1530)

Então, é só no final do percurso da vida, quando se cumpre o destino, que podemos

adquirir um caráter definitivo no que respeita à felicidade e à fortuna. Assim, Sólon diferencia

o momentaneamente afortunado (euotuxh/j) do realmente feliz (ollbioj), pois o

homem é todo vicissitude, e, portanto, ninguém deve julgar-se feliz antes que chegue sua morte. Nas palavras de Hartog: "A morte é signo de alteridade e intervém na grande partilha, 
sempre recomeçada, entre o mesmo e o outro: ela é um operador de diferença, ou seja, : 'Dize-me como morres e te direi quem és'” (1999, p. 161). ${ }^{65}$

Creso ouve, um a um, os motivos de orgulho e de compensações morais dos "virtuosos" que nada têm a ver com a qualidade por ele exibida como a mais invejável, a riqueza. Mas a incapacidade de se desprender das circunstâncias presentes veda-lhe a compreensão da máxima ilustrada por Sólon, segundo a qual “é mais vantajoso para o homem morrer do que viver", desde que a morte seja coroada de glória, como comprovam os destinos das figuras eleitas por ele:

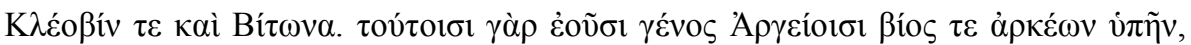

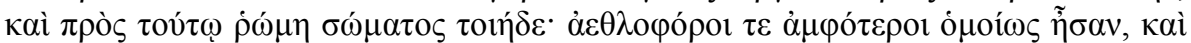

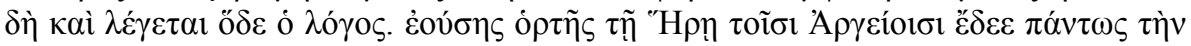

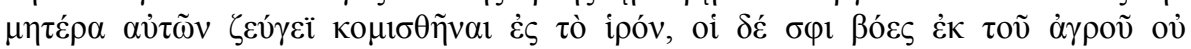

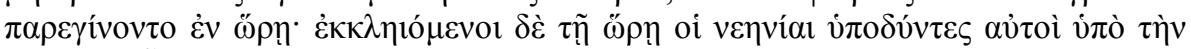

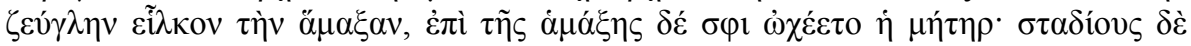

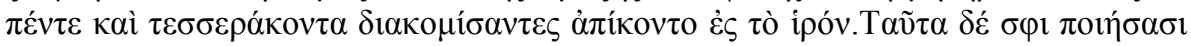

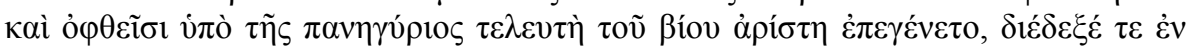

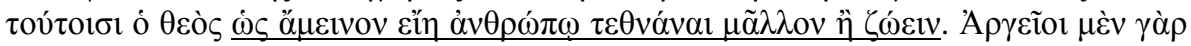

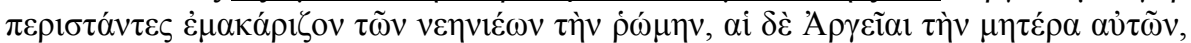

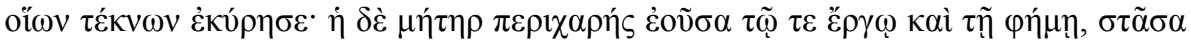

\footnotetext{
${ }^{65}$ Fazemos, aqui, uma breve digressão do tema desde tópico, buscando pensar na felicidade e se está depende do outro. É manifesto que todos os homens aspiram à vida feliz e à felicidade. Baseamo-nos em Aristóteles, mais precisamente em sua obra Ética a Nicômaco, para afirmar que, se muitos têm a possibilidade de alcançar tal vida feliz e tal felicidade, outros não a têm em virtude de algum azar ou vício de natureza, pois a vida feliz requer certo acompanhamento de bens externos, em quantidade menor para os indivíduos dotados de melhores disposições e em quantidade maior para aqueles cujas disposições são piores. Já outros, tendo a possibilidade de serem felizes, imprimem desde o início uma direção errada na sua busca da felicidade. Ainda segundo o filósofo, as pessoas felizes devem possuir as três espécies de bens: os exteriores, os do corpo e os da alma. A felicidade, para ele, não se esgota no prazer. Ela é entendida como o maior bem do homem e identifica-se com o viver bem e o fazer o bem. Essa boa vida, que todo ser humano almeja, é o que chamamos de felicidade e que se refere a certa forma de viver: não se trata de um estado, mas, sim, de uma atividade do homem e tal atividade deve seguir certas normas coerentes com a natureza humana. No entanto, como a natureza humana é complexa e muitas vezes apresenta tendências opostas, é preciso submetê-la a certas regras ou critérios racionais que a equilibrem. Conseguir esse equilíbrio é o que Aristóteles chama de possuir a virtude, componente essencial da felicidade. A virtude impede que tendências opostas entrem em choque trazendo efeitos destrutivos para o ser humano. Contudo, ainda que sejam necessárias, as virtudes não são suficientes para a vida feliz. A felicidade é a atividade daquele que age de acordo com os bons hábitos que adquiriu durante a maior parte de sua vida. A felicidade mais perfeita, então, é a que se baseia no exercício da virtude igualmente mais perfeita, da virtude de maior excelência, a sabedoria, que é a contemplação das verdades fundamentais da ciência e da filosofia: é o fim completo da vida humana. A pessoa feliz é auto-suficiente, na medida em que a sua felicidade depende dela própria e não de condições exteriores. A felicidade é um fim em si mesmo que consiste numa ação virtuosa. Aristóteles considera a existência de dois tipos de atividades: as atividades valiosas em si mesmas e as atividades valiosas para outros fins. A felicidade está entre as primeiras. A ela não falta nada: como ação virtuosa, não é divertimento. Embora os divertimentos pareçam ser um fim em si mesmos, eles podem causar mais danos do que benefícios. Pois as mesmas coisas parecem honoráveis e agradáveis para pessoas vis e desagradáveis e vis para pessoas decentes. Contudo, apenas o que é honorável e agradável para a pessoa virtuosa é que é digno de honorabilidade. Decorre daqui que a felicidade não pode ser encontrada na diversão, embora os divertimentos, sem excesso e na medida certa, possam ajudar ao relaxamento, preparando, assim, a pessoa para as coisas sérias. Portanto, não estamos diante de um estado, mas, sim, de uma atividade, a mais auto-suficiente de todas. Uma vez que a felicidade é uma atividade completa, ela inclui todos os tipos de bens e, alguns bens, como é o caso da saúde, dependem da sorte e, por isso, ela tem alguma influência nesta atividade. Mas é necessário frisar que os maiores componentes dela, isto é, as virtudes do pensamento e as virtudes do caráter, não dependem da sorte.
} 


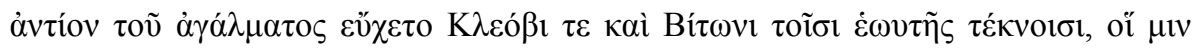

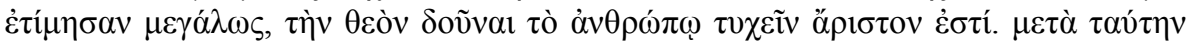

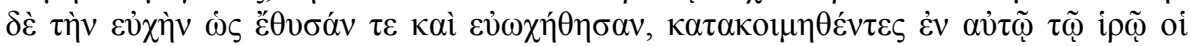

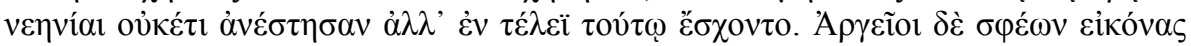

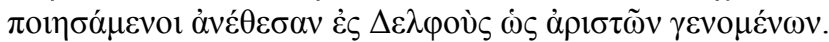

"Cléobis e Bìton. Estes, de facto, que eram de raça argiva, tinham suficientes meios de subsistência e eram, além disso, dotados de grande força física. Os dois foram igualmente atletas vencedores e deles conta-se ainda a seguinte história. Numa altura em que os Argivos celebravam a festa em honra de Hera, tornava-se absolutamente necessário que sua mãe fosse levada num carro ao templo, mas os bois não chegaram a tempo do campo. Constrangidos pela falta de tempo, os jovens submeteram-se eles mesmos ao julgo, puxaram o carro em que sua mãe se colocara e, numa distância de quarenta e cinco estádios, transportaram-na até o santuário. Depois de fazerem isto, sob os olhares de toda a assembleia, sobreveio-lhes o melhor termo de vida, e neles mostrou a divindade ser melhor para o homem morrer do que viver. Os Argivos, rodeando os jovens, elogiavam a sua força e as Argivas a mãe que tais filhos teve. Ela, cheia de júbilo pela façanha e pelos elogios, de pé diante da estátua, pediu que a deusa concedesse aos seus filhos Cléobis e Bíton, que tanto a haviam honrado, o melhor que um homem pode obter. Depois desta prece, uma vez realizados o sacrifício e o banquete, os jovens adormeceram no próprio templo e não se levantaram mais. Foi esse o fim que tiveram. Os Argivos ergueramlhes estátuas que consagraram em Delfos como homens excelentes que eram". (HERÓDOTO, I, 31. Grifo nosso)

Creso rejeita as palavras de Sólon e, em sua cegueira, precipita-se tragicamente em sua queda que é pormenorizadamente descrita por Heródoto: ele perderá o herdeiro, o reino, a riqueza, a liberdade e quase a vida. ${ }^{66}$ Creso, cuja desgraça é apresentada como uma história para exemplificar a arrogância de se considerar feliz em um mundo em que é impossível controlar os destinos, demonstra que a riqueza, embora possa ajudar a satisfazer nossos desejos e até nos proteger de determinadas dores, é inútil, no final, para combater a má sorte ou a ira dos deuses, já que ninguém basta a si mesmo. ${ }^{67}$ Assim, o receptor das Histórias vê-se

\footnotetext{
${ }^{66}$ Entendemos que, contudo, perder a vida, no contexto que ora abordamos, não seria um mal tão grande. De fato, terrível seria e é perder tudo e continuar vivo.

${ }^{67}$ Segundo Aristóteles, os bens que se relacionam com a alma são as ações e atividades psíquicas. Estes, por sua vez, são os bens no sentido mais verdadeiro da palavra, pois, segundo o filósofo, o homem feliz que vive bem, age bem (Ética a Nicômaco, 1098a10-15). O homem que não se compraz nas ações nobres não é um homem bom. Ninguém consideraria justo um homem que não sente prazer em fazer o bem. Portanto, segundo o filósofo, a felicidade é a melhor, a mais nobre e a mais aprazível coisa do mundo, como já introduzimos em referência anterior. Ela é nossa busca e objetivo final. Ainda de acordo com o filósofo, a felicidade não é facilmente alcançada sem outros bens - meios no qual se chega a ela. Dificilmente um homem que não tem amigos ou filhos, ou os tem e eles são perversos, ou a morte levou os bons, alcançará a felicidade. Esta, alcançada por acaso não é tão realizadora quanto aquela que foi intensamente procurada, diz o filósofo. Um homem feliz é aquele que foi feliz durante a vida até nos momentos mais difíceis, aquele que agiu com moral e nobreza (Ética a Nicômaco, 1100b10-30). Ele conclui que a felicidade é, então, uma virtude e, portanto, para entendê-la é necessário que estudemos as virtudes. A argumentação dada é a seguinte: um homem deve amar a si mesmo acima de tudo? Isto não seria característica de um egoísta? Mas, o melhor amigo de um homem é aquele que visa o seu bem acima de tudo. Ainda que ninguém saiba disso, esta característica se enquadra perfeitamente no amor que deve ter pra si mesmo. Para ser amigo de alguém, o homem deve ser antes de tudo o seu melhor amigo. Contudo, diferente do modo que a maioria o é, isto é, não sendo egoísta. Todo o homem feliz necessita de amigos. Aquele que está em dificuldade precisa de amigos para ajudá-lo a crescer. E o que tem abundância precisa para ter alguém a quem ajudar. Mesmo que um homem possua toda a riqueza, ainda assim, não seria feliz. Pois, para Aristóteles, o homem é um animal "cívico", e a convivência social é essencial. Diz ele que a felicidade é uma atividade
} 
confrontado com um paradigma célebre da dignidade na morte, isto é, a máxima segundo a qual a riqueza não garante a felicidade.

A ironia do destino, que confere grandiosidade trágica às personagens dramáticas, conduz, sinuosa, os passos de Creso na direção do abismo. A frustração do rei bárbaro resulta na reflexão sobre o equívoco do homem na obra herodotiana, isto é, a percepção superficial do mundo e das coisas, tal qual nas tragédias. A obstinação e a cegueira dos homens - que, em geral, nas Histórias, são identificados com os reis bárbaros e os tiranos gregos - impele-os para a desgraça, em muitos casos coincidente com a morte:

Qual protagonista da tragédia grega de Heródoto, Creso acabará por receber da vida a lição de humildade reservada à pessoa cuja soberba era responsável por um alheamento insolente face à vigilância constante dos deuses. A arte dramática colocada na encenação da "aprendizagem pela dor". A importância de um estudo atento sobre a conversão provisória da figura do rei prepotente (...) deriva, precisamente, do fato de essa ser a demonstração prática do pensamento herodotiano de acordo com o qual a ocasião definitiva para avaliar a felicidade do indivíduo reside na morte. (SOARES, 2003, p. 70)

No lógos de Creso, a vida humana, sob a perspectiva da morte, é como cena de tragédia. Temos um exemplo claro da proximidade dos assuntos representados nas tragédias e os apresentados por Heródoto quando percebemos o homem subordinado a forças superiores sobre as quais ele não detém o mínimo domínio, como os deuses ${ }^{68}$ e a Sorte $(\mathrm{Tu} / \mathrm{xh}) . \mathrm{Na}$ concepção de nosso autor e, provavelmente, de seus contemporâneos, a felicidade não era um sentimento, nem um estado subjetivo, ponto ressaltado pela ironia de que Creso, no começo, achava que era feliz, recebendo, ulteriormente, prova do contrário. A felicidade era, então, a caracterização de uma vida inteira e só podia ser determinada com a morte. Considerar-se feliz antes disso era prematuro e uma ilusão, já que o mundo é cruel e imprevisível,

constante. Por isso, temos que executá-la sempre. Então, seremos felizes. Portanto, a amizade que se busca pelo prazer deve ter um limite. Como, também, devem ter limites as amizades que visam à utilidade, pois ter que retribuir serviços em excesso não é bom. E não ter tempo de vida o suficiente para tal não é característica do homem digno de felicidade. Na amizade nobre, dos bons amigos, seu número é fixado pela convivência. Quanto mais amigos com os quais conseguirmos conviver, melhor estaremos, uma vez que, segundo o estagirita, o convívio é a principal característica da amizade e não conseguiremos conviver devidamente com um número muito grande de amigos. Aristóteles conclui que a amizade é mais nobre quando estamos na riqueza, pois é nela que vemos e ajudamos a quem amamos. A amizade se faz mais necessária na dificuldade, onde os amigos nos ajudam a superar as dificuldades e a prosperar (Ética a Nicômaco, Livro IX).

${ }^{68} \mathrm{Na}$ verdade, o divino passa a ser representado por Heródoto como parte integrante do jogo das sociedades. A importância da mediação está no fato de que a palavra divina dará a forma final da vontade humana. Mediação, uso da palavra, interpretação, elementos integrantes do mundo dos homens, do jogo de vida e morte das sociedades humanas ligado à vontade divina. 
comandado por forças que estão além do controle humano: um capricho dos deuses, o dom da boa fortuna, a determinação do destino. ${ }^{69}$

A trajetória do tirano lídio se assemelha àquela do herói trágico Édipo. Do mesmo modo que, para o rei de Tebas, a Moi ra trágica reserva o estabelecimento e a ruína de seu poder real, para Creso, o destino reserva tão somente a ruína, o fim de uma dinastia marcada, desde o início, por aquilo que Atenas reconheceria como transgressão (RIBEIRO, 2005).

Os percursos dessas duas figuras, Creso, em Heródoto, e Édipo, em Sófocles, apresentam, em certa medida, estreitos laços de semelhança que podem ter mesmo causas verificáveis. Creso, semelhantemente a Édipo, carrega a mácula do crime de seu quarto ancestral. $\mathrm{O}$ assassinato perpetrado por Giges reencontra-se com a punição na figura de Creso, cuja história responde ao insaciável apetite trágico da maldição ancestral. O déspota de Heródoto e o herói trágico de Sófocles são dois soberanos (tu/rannoi) movidos pela u3briv, ${ }^{70}$ isto é, desconhecem a medida humana e, portanto, negam sua natureza. ${ }^{71} \mathrm{O}$ nãoreconhecimento da medida humana, da fragilidade intrínseca a sua condição e a negligência no que concerne às constantes transformações da sorte dão a Creso, poder-se-ia dizer, os atributos de um u9bristh/v. ${ }^{72}$ Creso, subjugado a Ciro, e Édipo, o cego de Colono, privado do poder real, parecem percorrer de forma semelhante seus caminhos (RIBEIRO, 2005).

\footnotetext{
${ }^{69}$ Temeroso é o tema do destino (Moi ra). A liberdade, para os gregos, é mais facilmente compreendida a partir da perspectiva da tragédia grega. Ela se caracteriza, fundamentalmente, pelo sentimento de que há uma desproporção entre as causas e os efeitos. Ou seja, como explicar o fato de que, para intenções boas, temos uma resultante de conseqüências más? Em Antígona de Eurípedes, por exemplo, temos uma abertura para uma contradição. De um lado, temos um sentimento de que é justo procurar o bem e realizar a liberdade, apesar de forças exteriores, estranhas e desconhecidas, chocarem-se com a vontade humana. E, de outro lado, a ideia de que ninguém pode escapar ao destino, visto pertencer o êxito aos deuses, cabendo ao homem apenas o esforço. Fica claro que apesar do mais cruel destino, existe alguma coisa que pertence única e exclusivamente ao homem: a sua atitude pessoal e livre diante dos acontecimentos. Em relação ao destino, podemos considerar duas abordagens: numa, representada na obra de Ésquilo, há o caráter mais pessimista. Esta é, precisamente, a que acentua o desamparo do homem frente à força do destino; a outra, presente em Eurípides, possui um caráter moralista, que acabará prevalecendo na idade clássica, visto fundamentar-se sobre a descoberta da responsabilidade pessoal na esfera da realidade, na qual o homem pode estender seu poder de escolha, tendo como consequências o mérito ou a vergonha.

${ }^{70}$ Sobre a u3briv, como ausência do senso de medida: "É justamente esta desmedida, própria da natureza do soberano, que leva Creso à derrocada. Imerso em hýbris, o déspota asiático parece identificar-se, pela ótica de Heródoto, ao que não se distancia da nossa idéia de 'transgressor': o ímpeto expansionista, assomado à crença em sua superioridade, leva-o à perda de seu império" (RIBEIRO, 2005, p. 88).

${ }^{71}$ Aliás, Myres (1952) chama a atenção para a presença do que chama de "herói trágico" nas Histórias. Parecenos, de fato, que há a construção da figura de Creso à maneira de um "herói trágico", dado seu percurso na narrativa de Heródoto. O tirano persa surge como o primeiro de uma série, que inclui, também, Ciro, como uma espécie de Édipo herodotiano.

${ }_{72}$ Ainda que tal termo não seja utilizado em momento algum por Heródoto para caracterizar o rei lídio.
} 
De fato, o ser humano vê-se dotado de uma fragilidade inata e é em consequência dessa subordinação que Creso assistiu ao desmoronamento da sua principal crença, segunda a qual a posse de uma riqueza vastíssima devia ser entendida como certificado de ventura. Parece-nos que, ao invés de estabelecer a essência da felicidade, a entrevista com Sólon acaba, de forma paradoxal, por provar a impossibilidade de aplicar semelhante conceito à vida humana. Com efeito, a noção de que ninguém pode ser julgado feliz antes de terminados os seus dias fazia parte da vasta galeria de máximas da moral popular grega. É a caracterização de Creso e a sua cegueira diante dos sinais da fragilidade humana que o aproximam das figuras da tragédia, ${ }^{73}$ porque, embora essas personagens tivessem inevitavelmente contribuído para sua ruína pela arrogância e pela ingenuidade, o cerne do dilema trágico é o de que não há resolução simples para os conflitos, não há decisões sem preços altíssimos, não há finais felizes e fáceis.

As histórias introduzidas na narrativa do historiador de Halicarnasso relacionam-se uma com a outra por analogia de conteúdo - como no caso de Creso e de Candaules - e pelo parentesco inegável com o gênero dramático. A similaridade entre alguns passos das Histórias e a tragédia ática de meados do século $\mathrm{V}$ é um dado reconhecido pela maioria dos helenistas e pretendemos comentá-la um pouco mais ao discorremos sobre o lógos de Candaules. De fato, os pontos em comum, de estrutura e conteúdo, entre os pequenos lógoi e a tragédia, são bastante evidentes. Abordemos, pois, o "lógos dramático" 74 de Candaules. ${ }^{75}$

Candaules comete o mesmo erro de Creso: julga-se o mais feliz dos homens, quer convencer outro disso e o seu lógos é, como o discurso de Sólon, uma história de ficção que tem como objetivo introduzir a figura de Creso na qualidade do primeiro rei oriental a ser tratado nos lógoi das Histórias. A narrativa remete o leitor a cinco gerações anteriores, até Giges, que, matando Candaules - o último dos Heraclidas -, e casando-se com a rainha, se tornou o iniciador da dinastia na qual Creso estava inserido. Com efeito, Apolo, pelo oráculo

\footnotetext{
${ }^{73}$ Bem representada entre os três grandes trágicos, a repetição mais célebre da ideia da cegueira diante dos sinais da fragilidade humana é inegavelmente explicitada pelo Rei Édipo de Sófocles, no qual assinalamos os versos 1524-1530, já transcritos.

${ }^{74}$ Immerwahr (1966) identifica como fator constante uma sucessão de episódios de ascensão e queda dos déspotas asiáticos e considera tal fato como uma espécie de peripécia dentro da obra herodotiana; segundo o autor, haveria um padrão de desenvolvimento constante na apresentação dos lógoi dos tiranos: nascimento e ascensão ao poder, reinado até o apogeu e decadência e/ou desfecho em ruína. Verifica-se, assim, a semelhança entre o tratamento dos lógoi narrados e a estrutura da tragédia, considerando a similitude de percurso dos soberanos asiáticos e a do herói trágico, por exemplo.

${ }^{75} \mathrm{O}$ inevitável destino e a intervenção do divino, o ciclo trágico de ascensão e queda, a percepção de que o homem está sempre sujeito ao tempo e às transformações por ele ocasionadas, a maldição ancestral e a incompatibilidade entre intenção e ato são alguns dos motivos trágicos que podemos identificar no lógos lídio.
} 
de Delfos, anuncia que a punição do crime de Giges recairia em sua quinta geração, ou seja, sobre Creso.

Candaules, como Creso, precisava mostrar aquilo que julgava ter de mais valoroso em relação aos outros, isto é, sua bela rainha. Para expor, então, sua "fortuna" a seu homem de confiança, o rei, verdadeiro mestre na arte do enredo e da persuasão retórica, começa por envolver Giges numa teia de sedução. Consciente dos obstáculos psicológicos que iria encontrar junto de seu empregado quanto a uma proposta que se chocava diretamente com o código de valores da sociedade em que se inseriam, Candaules promove o elogio insistente da beleza da esposa, associado a uma estratégia evidente de pressão. Põe em prática, então, tanto o discurso dos louvores feitos à formosura da rainha, quanto o convite a que Giges a espiasse nos seus aposentos:

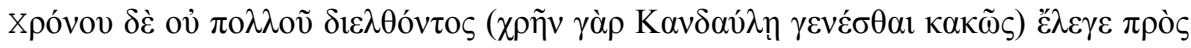

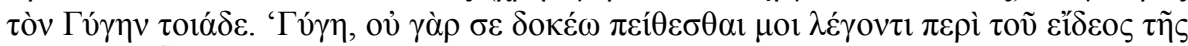

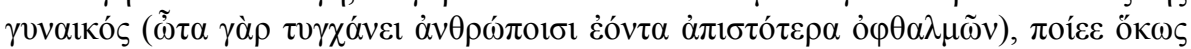

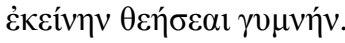

Não muito tempo decorrido - pois queria o destino que lhe acontecesse mal -, disse Candaules a Giges o seguinte: "Giges, parece-me que não acreditas no que te digo acerca da beleza de minha mulher. Já que, para os homens, os ouvidos são mais incrédulos do que os olhos, faz de modo a contemplá-la nua”. (HERÓDOTO, I, 8)

Giges cumpre a ordem e, neste ponto, Heródoto é claro na explicação que dá. A força da necessidade assim o obrigava: tanto a ele, que, como súdito, tinha uma dívida de obrigação para com o seu senhor, como a Candaules, sobre quem recaía a fatalidade de um destino desventuroso.

Claramente é demandado a Giges o testemunho visual como critério de validação do juízo emitido. Se, a princípio, ele começa por encarnar a voz do bom senso e se apoia nas leis ancestrais para rebater a missão de que lhe incubia o seu senhor, este, de imediato, prontificava-se a elaborar um plano (e0gw/ mhxanh/somai) para contornar a "lei":

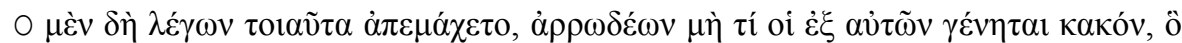

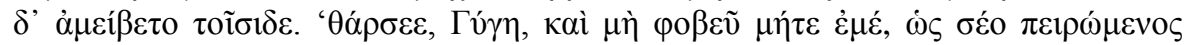

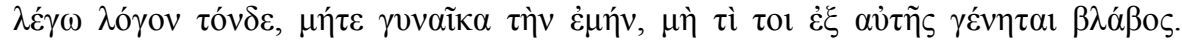

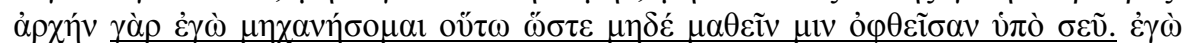

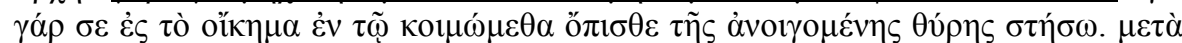

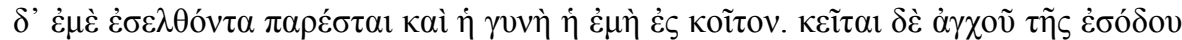

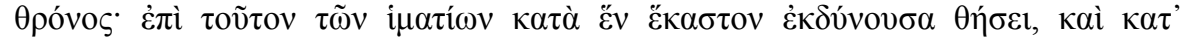

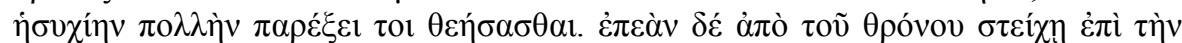

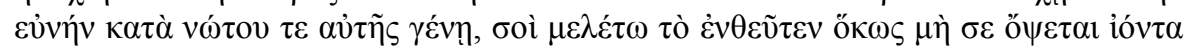

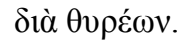


Com tais palavras resistia à proposta, temendo que dali lhe viesse qualquer dano. Mas Candaules respondeu-lhe deste modo: "Tranquiliza-te, Giges, e não tenhas receio nem de mim, que te faço esta proposta para te por à prova, nem de minha mulher, que dela te possa vir algum dano. Eu planearei as coisas de modo que ela nem sequer saiba que foi observada por ti. Introduzir-te-ei no compartimento em que dormimos, por trás da porta aberta. Depois de eu entrar, também a minha mulher se apresentará para se deitar. Próximo da entrada há uma cadeira, sobre a qual ela colocará os vestidos, um após o outro, ao tirá-los, e ser-te-á possível observá-la com toda a tranqüilidade. Mas quando ela, da cadeira, se dirigir para o leito e tu ficares nas tuas costas, procura então que não te veja, ao franqueares a porta". (HERÓDOTO, I, 9. Grifo nosso)

A solução é, na verdade, muito simples e ao mesmo tempo astuta. A fórmula encontrada para burlar a norma era a de que bastava que a rainha não soubesse que estava sendo vista (w3ste mhde_ maqei n min o0fqei san u9po\ seu ). O papel de Giges era o de mero instrumento nas mãos de Candaules: ele não só deveria cumprir um plano que não elaborou, bem como a execução deste ficaria a cargo de seu senhor, que esclareceu caber-lhe a função de introduzir o empregado nos aposentos reais.

Enquanto Candaules, pelo atentado que elabora ao pudor da companheira, demonstra uma ignorância absoluta sobre a determinação de seu caráter, a rainha, assim que vê o espião retirar-se dos aposentos, imediatamente tece um juízo acertado da situação. Só podia ter sido o marido a armar-lhe semelhante cilada. A importância dos costumes e das leis dos povos se afirma nesta primeira história de ficção. Desafiar os costumes de pudor, como fez Candaules, ${ }^{76}$ causar-lhe-ia graves conseqüências, dando à rainha, portanto, o direito de se vingar dos autores da ofensa que lhe havia sido feita: ${ }^{77}$

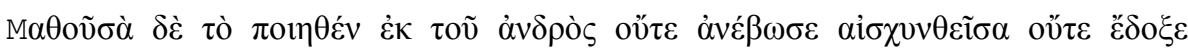

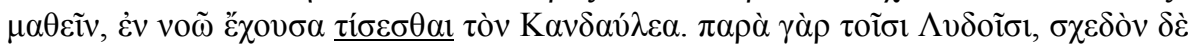

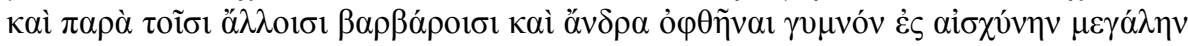

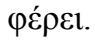

Compreendendo o que tinha feito o marido, não gritou de vergonha nem mostrou ter percebido, por ter na mente vingar-se de Candaules. É que entre os Lídios, como entre quase todos os outros bárbaros, ser visto nu traz grande vergonha, mesmo para um homem. (HERÓDOTO, I, 10. Grifo nosso)

\footnotetext{
${ }^{76}$ Para Candaules é felicidade que agentes externos saibam que ele é feliz. Há aqui uma necessidade de reconhecimento. Parece tratar do desejo de se tornar cada vez mais o que se é, de se tornar tudo o que se é capaz de ser, levando-o a cometer fosse qual fosse o ato, independentemente da posição social e dos costumes nos quais estava inserido. Acreditamos que a felicidade humana aparecerá na figura de Candaules como um misto de conquistas materiais e da necessidade de que os outros as reconhecessem, tal qual, aliás, para Creso.

77 Esta história revela, na verdade, que a narração de Heródoto é aproximada da tragédia. Trata-se de uma tragédia narrada na qual Heródoto trabalha como mensageiro que transforma o acontecimento fora da cena em narrativa carregada de dramaticidade no momento em que o reconta ao público e às demais personagens.
} 
Como rainha vingativa, ela tem poder, mas este geralmente é menosprezado pelo elemento masculino opositor. Sua vingança, contudo, é inteligente e fria e marca a narrativa com a mostra de que a manutenção de sua vida, dentro da estrutura dos costumes da época, dependia da morte de seu marido. Sendo assim, descoberta a trama, a rainha, para se vingar (ti/sesqai) do ultraje de que foi vítima, convoca Giges com a finalidade de lhe dar a escolher uma de duas soluções:

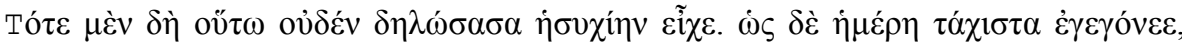

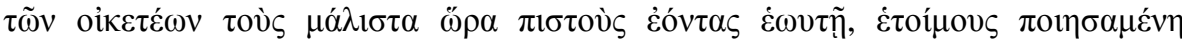

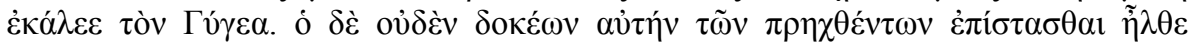

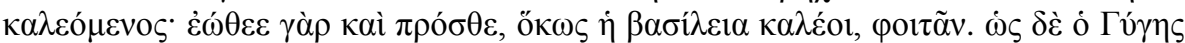

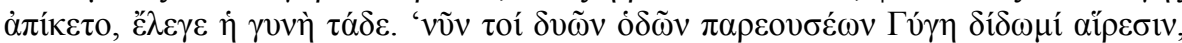

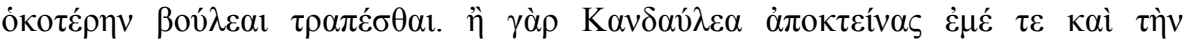

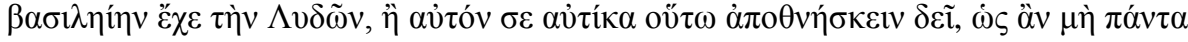

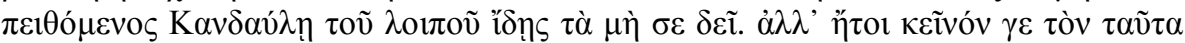

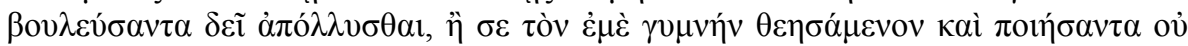


Deste modo pois, nada dando a entender, manteve-se tranquila. Mas logo que o dia surgiu, depois de preparar os servidores que considerava serem-lhe mais fiéis, chamou Giges. Este, pensando que ela não sabia nada do que tinha acontecido, acudiu ao chamamento. Já antes, na verdade, costumava apresentar-se, sempre que a rainha o chamava. Quando Giges chegou, disse-lhe ela o seguinte: "Das duas vias que agora se te apresentam, Giges, eu dou-te a escolher a que desejares seguir: ou matas Candaules e tens-me a mim e o reino dos Lídios, ou és tu próprio que tens de morrer de imediato, para que, obedecendo em tudo a Candaules, de futuro não vejas o que não deves. Sim, tem de morrer ou aquele que planeou esta trama ou tu que me observastes nua e fizestes coisas que te não eram lícitas”. (HERÓDOTO, I, 11)

Procurando, em um primeiro momento, como fizera com a proposta de Candaules, escapar do dilema perante o qual é colocado, posto aqui como uma verdadeira aporia trágica, Giges enfatiza o fator necessidade como um processo, mal disfarçado, de ilibar-se da culpa de um homicídio que consente em perpetrar, uma vez que dele, isto é, da morte de outro, dependia sua própria vida.

Deixando uma vez mais fluir o seu habitual pendor para a dramatização, Heródoto termina o relato da história do monarca bárbaro com paixão, vingança e morte. Notamos, no geral, que na descrição das origens dos reis, valoriza-se a forma como nascem, como chegam a reinar ou chegam ao ápice de sua soberania. Mas a descrição de sua ascensão até o clímax de seu poder, que se ocupa, basicamente, das guerras, recebe de Heródoto um tratamento mais rápido do que a descrição do seu declínio. De fato, a queda dos reis recebe descrição requintada e detalhada, esboçando o conjunto de fatalidades que levam, geralmente, à morte.

A imagem dos muitos "enganados" que permeiam as Histórias e dos quais recordarmos, aqui, apenas dois dos maiores, Creso e Candaules, partilha com os heróis 
trágicos a essência da própria tragicidade, ou seja, a cegueira de quem não consegue ver o que está para além da aparência, quer dos atos, quer das palavras. ${ }^{78}$ Percebemos, assim, que o texto herodotiano revela o cuidado de demonstrar a quota de responsabilidade do homem na construção da sua desgraça, apesar da interferência dos deuses. Certamente que o público do século V a.C., que estava bastante familiarizado com o teatro, não poderia deixar de sentir nas histórias dos infortúnios destes dois reis bárbaros o eco das forças que enformam o universo das personagens trágicas, também elas membros de famílias reais e por isso mesmo paradigmáticas. Se tanto o fim de Creso como o de Candaules resultam da relação erro (a (marti\&a)/compensação, onde a morte é a pena máxima, ${ }^{79}$ é na dramatização da vida dos dois monarcas que vêm expressos os fios condutores que fazem deles personagens de uma tragédia narrada: a intervenção do destino e a cegueira do protagonista à vontade dos deuses, ${ }^{80}$

\footnotetext{
${ }^{78}$ Mais uma vez destacamos no Rei Édipo de Sófocles, mais precisamente em seu protagonista, o paradigma da ilusão trágica, resultante da incapacidade humana para ver além da aparência.

${ }^{79}$ Vale lembrar, aqui, que no lógos de Sólon, a pena máxima, a morte é prova definitiva de felicidade. A morte é, de fato, apresentada por Sólon na qualidade de superlativa.

${ }^{80}$ Em Heródoto percebe-se um "fatalismo" ou destino trágico marcado pela crença de que os homens seriam impotentes diante dos desígnios divinos. Isto fica evidente, por exemplo, nos capítulo 163 e 164 do Livro IV,

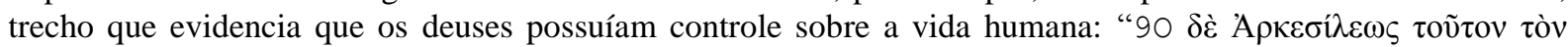

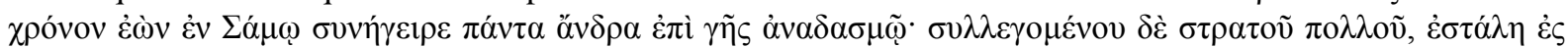

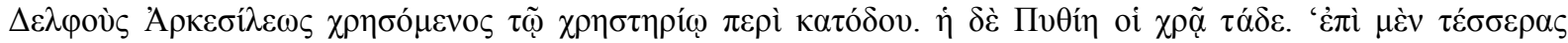

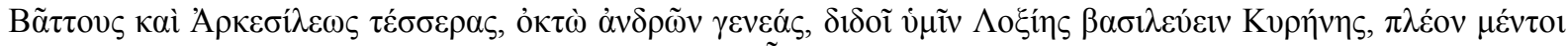

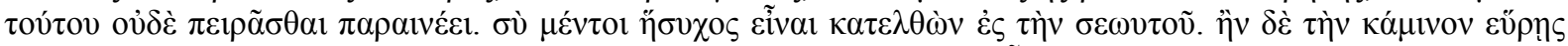

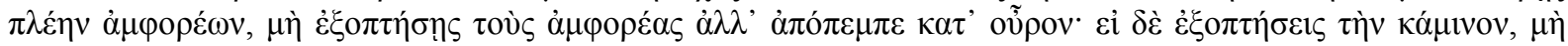

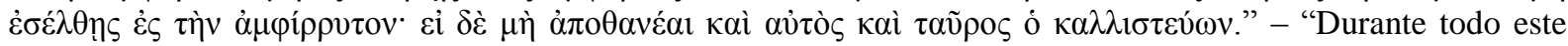
tempo, Arcesilau permaneceu em Samos e com a promessa de atribuição de terras ia congregando todos os homens que por essa zona passavam. Depois de reunir um grande exército, Arcesilau enviou a Delfos uma embaixada para interrogar o oráculo acerca do seu regresso à pátria. E a Pítia respondeu com estas palavras: 'Durante o reinado de quatro Batos e de quatro Arcesilaus, durante oito gerações de homens, Lóxias permitiuvos governar em Cirene; mais do que isso, não vos aconselha a tentar. Quanto a ti, aconselha-te e ficares sossegado, ao regressares à pátria. Se acaso encontrares o forno cheio de ânforas, não cozas nele as ânforas; deixa-as antes partir com vento favorável. Se, pelo contrário, as cozeres no forno, não vás para o recinto cercado

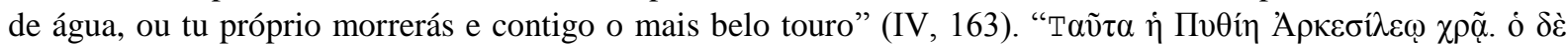

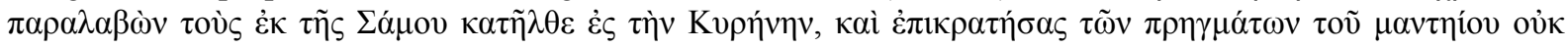

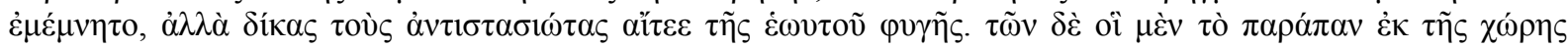

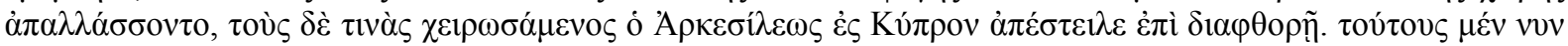

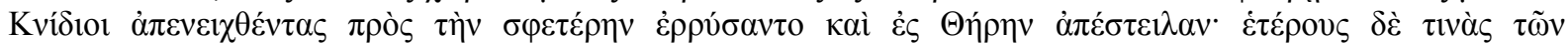

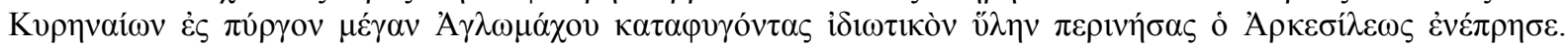

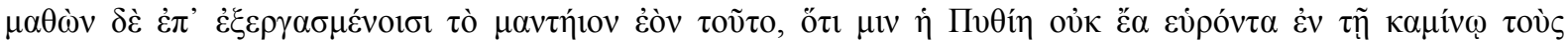

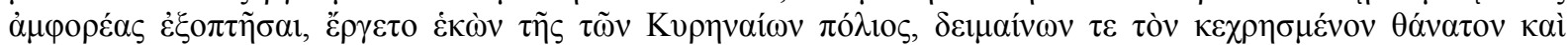

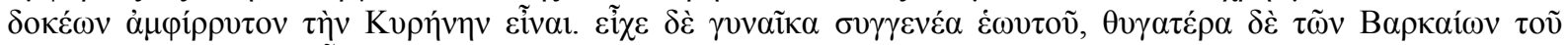

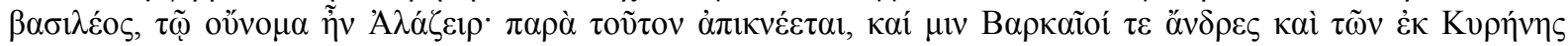

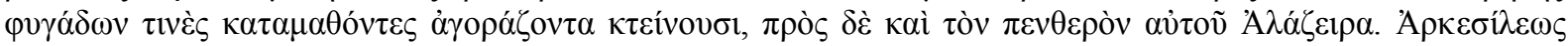

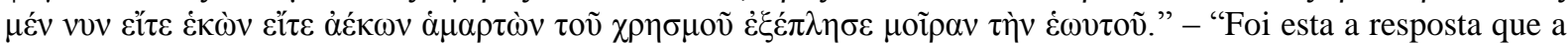
Pítia deu a Arcesilau, e ele regressou com os Sâmios a Cirene. Controlando perfeitamente todos os acontecimentos, nunca mais se lembrou do oráculo e satisfazia nos adversários políticos a sede de vingança pelo seu exílio. Alguns deles abandonaram de vez a região; outros houve que Arcesilau conseguiu apanhar: mandouos para Chipre, para serem condenados à mote, mas foram desviados pelos ventos para a região dos Cnídios, que os salvaram e os encaminharam para Tera. Outros ainda refugiaram-se numa grande torre que era propriedade privada de Aglómaco: Arcesilau amontoou lenha a toda a volta e deitou-lhe fogo. Reconhecendo, depois de todos estes actos, que tudo não passava afinal da profecia do oráculo decidiu sair de Cirene, por recear a morte
} 
bem como suas atitudes e escolhas, transformando-os em únicos responsáveis pela sua (má) sorte.

Podemos mesmo encontrar na figura dos dois reis traços do que Aristóteles definiu no século IV como propósitos do caráter do herói trágico. ${ }^{81}$ Ambos são figuras que passam de uma situação de felicidade para o infortúnio (e0c eu0tuxi/av ei0v dustuxi/an), não por terem cometido alguma maldade ou ato perverso (mh/te dia $\backslash \mathrm{kaki} / \mathrm{an} \mathrm{kai} \backslash$ moxqhri/an), mas devido a um erro grave (a0lla di' a9marti/an mega/lhn). Acreditamos que esta passagem da felicidade para o infortúnio pode mesmo ser entendida como uma espécie de peripécia, um dos elementos essenciais da tragédia, também segundo Aristóteles. Na Poética (1452a), ele define a peripécia como "uma mudança (metabolh/) para a direção oposta dos eventos, como dissemos, em conformidade, como insistimos, com o verossímil e necessário", ou seja, uma reversão de situação que leva Creso da condição de rei lídio à condição de estar privado do poder real e ainda subjugado a Ciro, mesmo que na condição de conselheiro do soberano persa; ou, à de Candaules, que passa de rei/marido da mais bela mulher à condição de morto por seu homem de confiança, que, por sua vez, ocupa seu lugar no trono e no leito da rainha.

A possibilidade de olhar a riqueza sob ângulos diferentes concorda com o universo mental do homem grego: "Conhecer-se a si mesmo, em vida, é saber-se mortal. Como a riqueza, todos os outros dotes não são definitivos, fazem parte do conjunto de coisas supérfluas de que se cercam os homens" (BRANDÃO, 2001, p. 164-165). O fato de que todos morrerão, independentemente da condição social de que desfrutam, constitui, de fato, a marca distintiva dos humanos enquanto a raça dos mortais. Da perspectiva grega, esse seria o dado mais característico da natureza humana, na medida em que ela se constitui, em oposição à natureza divina, pela marca da mortalidade. Os lógoi aqui apresentados apontam para a experiência de cada vida como alternância entre riqueza e pobreza, poder e impotência, vida e morte. E, neste sentido, o veredicto de Sólon sobre o grau de felicidade atingido por Creso é

vaticinada, supondo que a região cercada de águia era Cirene. Ora acontece que ele tinha por esposa uma sua parente, filha do rei dos Barceus, chamado Alazir; e foi precisamente ter com este, quando alguns homens de Barce e alguns do que tinham fugido de Cirene, se aperceberam dele na ágora e o mataram juntamente com o sogro. E foi assim que Arcesilau, que voluntária ou involuntariamente ignorara o oráculo, cumpriu seu destino" (IV, 164)

81 “Tal pessoa não é alguém proeminente em virtude e justiça ou alguém que caia em infortúnio através do mal ou da perversidade, mas através de qualquer falta; é alguém que pertence à classe daqueles que gozam de grande renome e prosperidade, tal como Édipo, Tiestes e homens insignes de famílias ilustres. A trama bem feita, então, deve ser simples mais que dupla, como alguns pretendem, com uma mudança não da infelicidade para a prosperidade, mas, ao contrário, da prosperidade para o infortúnio, causada não pela perversidade da personagem, mas pelo grande erro, pois é ela antes melhor que pior" (Poética, 1453a7-16). 
emblemático ao afirmar que só se sabe da felicidade de um homem quando, enfim, este chega ao momento de sua morte.

A narrativa de Heródoto, como a do mensageiro trágico, é, aqui, a daquele que "dá notícia" ${ }^{82}$ do fato que foi visto, fazendo com que aos demais saibam a verdade ${ }^{83}$ e tenham certeza do ocorrido. Ele manipula os fatos, levando ao conhecimento de seu público o que julga digno se ver, reavivando a memória ou fazendo recordar ${ }^{84}$ daquilo que os homens gregos não podem deixar cair no esquecimento. É ele quem anuncia e quem causa emoção prazer ou tristeza - com suas palavras. ${ }^{85}$

\subsection{Comportamento não-verbal: o sorriso sardônico no lógos de Cleômenes}

Pretendemos realizar, neste "trecho fantástico" referente ao lógos de Cleômenes, uma análise do comportamento não-verbal, como forma de aprofundarmo-nos ainda mais na narrativa dramática de Heródoto: o desafio aqui será o de analisar o sorriso sardônico de Demarato com o fim de seu "rival" - Cleômenes - por considerarmos que, nas Histórias, os objetos, membros e sons são dispostos de forma a mostrar caráter e emoção na ação, para conduzir o espírito sem a mediação do discurso (LATEINER, 1987). É justamente essa falta de mediação do discurso nosso ponto principal quanto ao que entendemos por "não-verbal".

Em artigo publicado em 1987 e intitulado Nonverbal Communication in the Histories of Herodotus, Donald Lateiner afirma que os estudos dos sinais acústico, visual, tátil e gustatório são um campo relativamente novo e inexplorado de forma sistemática pelos classicistas e historiadores antigos. Embora o artigo tenha sido escrito e publicado há pouco

\footnotetext{
82 “Ei) tou=to prw=ton dei= m'a)paggei=lai safw=v, eu] i!sq' e)kei=non qana\&Simon bebhko\&ta." - "Se devo começar dando certeza da notícia, podes estar certo; a morte o levou” (SÓFOCLES, Édipo Rei, v. 959-960).

83 “Ei) de $\backslash \mathrm{mh} \backslash$ le\&gw g' e) gw\& ta) lhte\&v, a) ciw= qanei=n." - "Se não digo a verdade, mereço a morte" (SÓCLES, Édipo Rei, v. 944).

84 “Kou)de\&n ge qau=ma, de\&spot': a)ll' e)gw $\backslash$ safw=v a)gnw=t' a) namh\&sw nin. eu] ga\r oi]d' o\#ti ka\&toiden, h[mov to\n Kiqairw=non to $\backslash p o n m$ o( me $\backslash n$ diploi=si poimníoiv, e)gw $\backslash$ d' e(ni\e)plhsi\&azon to=ide ta)ndri $\backslash$ trei=v o\#louv e)c h] ros ei)v a)rktou=pon e(kmh\&nouv xro\&nouv:" - "Não é de admirar, meu amo; mas eu lhe avivarei bem as lembranças. Há de recordar, sem dúvida, o tempo em que, ele com dois rebanhos e eu com um, passamos próximos um do outro no Citerão três temporadas de seis meses, da primavera ao outono;" (SÓFOCLES, Édipo Rei, v. 1132-1137).

85 "'Ek th=v Kori\&nqou. to $d$ ' e!pov ou (cerw= ta\&xa h\#doio me $\backslash n, p w=n$ d' ou)k a!n; a) sxa\&lloiv d' i !swv." - Corimto. Ouvindo quanto eu comunico, terás prazer por certo e dor, talvez" (SÓFOCLES, Édipo Rei, v. 936-937).
} 
mais de 20 anos, entendemos que a afirmação permanece um tanto atual, principalmente para o autor de Halicarnasso.

Quanto ao sorriso sardônico, consideramo-lo como, possivelmente, uma das formas mais elementares e arcaicas de comportamento. O nome de sardônico comporta uma ideologia acerca da natureza do fenômeno do riso, a qual permite uma das interpretações mais radicais e penetrantes sobre o comportamento do homem do mundo antigo. Observando-o, pode-se entrever o ímpeto e o impulso primário que move a personagem na situação específica de nossa análise, na perspectiva de um cômico teatral.

O sorriso sardônico normalmente é ligado à vingança e à morte. E, assim o é, desde o legendário Talo, ${ }^{86}$ "homem de bronze" que destruiu, com seu abraço incandescente, os sardos que tentaram invadir a ilha de Creta e deles riu perversamente; donde, então, a expressão "riso sardônico". Riso dos sardos ou pelos sardos, o sorriso sardônico é um riso de morte.

Passemos a uma breve recapitulação do episódio entre os reis espartanos, Demarato e Cleômenes, para o desenvolvimento de nossos argumentos. Cleômenes, da família dos Axíadas, sucede seu pai Anaxândrides II no trono de Esparta e governa conjuntamente com o segundo rei, Demarato. A associação dos dois soberanos é problemática, pois Demarato refreia as ações de Cleômenes. Assim, este último acaba por expulsar o outro do trono, hostil, sobretudo, às suas investidas contra Atenas e Egina, indo, então, Demarato refugiar-se com Dario I. Na verdade, e segundo Heródoto, as acusações feitas a Cleômenes eram mais por inveja e ciúme que por qualquer consideração aos atenienses ou eginetas:

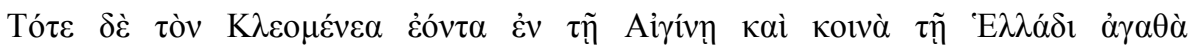

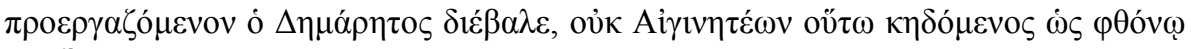

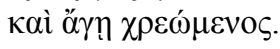

Ora enquanto Cleómenes estava em Egina e trabalhava pelo bem comum da Grécia, Demarato andava a acusá-lo, não tanto preocupado com os Eginetas, mas antes movido pela inveja e pelo ciúme. (HERÓDOTO, VI, 61)

A disputa entre os dois reis lacedemônios, entretanto, remonta à Aríston, também rei espartano, que não conseguira filhos das mulheres que desposara. Disposto a ter um herdeiro, desposou, em uma terceira união, a esposa de seu amigo Ageto, utilizando-se do seguinte recurso:

\footnotetext{
86 "Ligado, pelo seu nascimento, a Hefesto ou Dédalo, Talo era tanto um ser humano como um autômato de bronze. Guardava a ilha de Creta do rei Minos, com uma vigilância e um zelo excepcionais e impedia os viajantes de aportarem às costas da ilha: lapidava-os e queimava-os, apertando-os, com o próprio corpo, que ele tinha previamente levado ao rubro no fogo. Mas um dia Medéia, com os seus encantamentos, conseguiu enlouquecê-lo e Talo rompeu a veia do pé que era o único ponto vulnerável do seu corpo. Diz-se também que Filoctetes lha perfurou com uma flecha" (SCHMIDT, 1985, p. 249).
} 


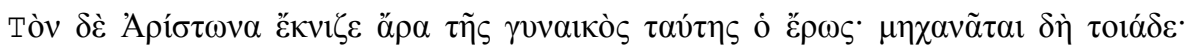

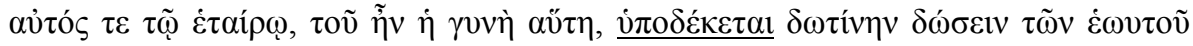

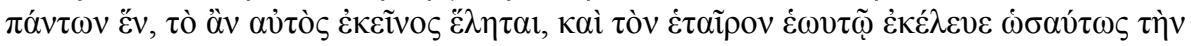

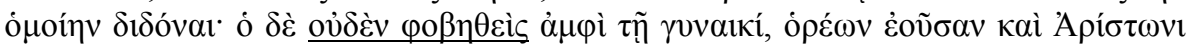

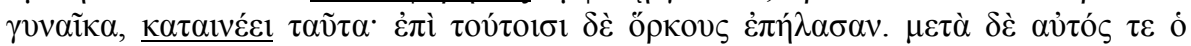

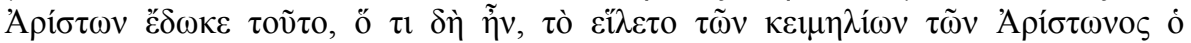

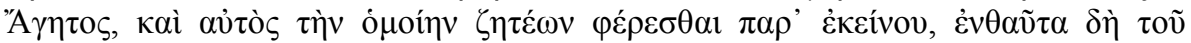

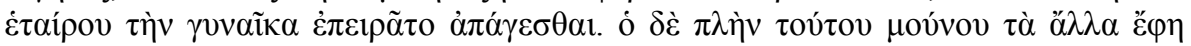

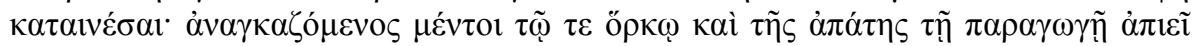

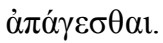

Acontece que Aríston ficou inflamado de amor por esta mulher e, por isso, engendrou o expediente seguinte: prometeu ao companheiro, a quem a mulher pertencia, dar-lhe um presente à escolha de entre todas as coisas que possuía, e convidou o amigo a fazer o mesmo em relação a si. Aquele não receou pela mulher, visto que Aríston já tinha uma; aceitou a proposta e obrigaram-se a cumprir a promessa, através de juramentos. Depois disto, Aríston deu a Ageto o que este escolhera entre os seus tesouros; e ele próprio procurou obter do outro a contrapartida, pretendendo, então, levar para casa a esposa do amigo. Este disse que tinha concordado em ceder tudo mais à excepção da mulher, mas, forçado pelo juramento e pela manobra falaciosa de Aríston, teve de a deixar partir. (HERÓDOTO, VI, 62. Grifo nosso)

Neste ponto, faz-se importante comentar acerca dos atos de fala, isto é, das palavras que fazem a ação, significativos para uma visão performativa da linguagem no trecho que ora nos propomos analisar. Entendemos que dizer é transmitir informações, mas é também, e, sobretudo, uma forma de agir sobre o interlocutor e sobre o mundo circundante.

O trecho se inicia com o verbo "prometer". Temos nele nosso primeiro ato de fala, pois a palavra "prometeu" realiza a própria ação. Tal enunciado, no exato momento em que é proferido, realiza a ação denotada pelo verbo, ou seja, não serve para descrever nada, mas sim para executar o próprio ato - ato de prometer. É preciso observar, no entanto, que o simples fato de proferir um enunciado performativo não garante a sua realização. Para que um enunciado performativo seja bem sucedido, ou seja, para que a ação por ele designada seja de fato realizada, é preciso, ainda, que as circunstâncias sejam adequadas. Um enunciado performativo pronunciado em circunstâncias inadequadas não é falso, é sem efeito: ele simplesmente fracassa.

Observamos que no trecho das Histórias aqui transcrito temos dois critérios que satisfazem as necessidades para que um enunciado performativo seja bem sucedido. São eles: verbo na primeira pessoa do singular na forma afirmativa e na voz ativa; e, o falante, Aríston, tem autoridade para executar o ato - prometer o que mais agradasse a Ageto. Assim, quando se enuncia a frase "prometeu a Ageto dar-lhe o que mais lhe agradasse", realiza-se o ato de 
promessa, o ato que se realiza na linguagem, ou melhor, trata-se de um ato que não se realiza na linguagem, mas pela linguagem.

É essencial, também, que as circunstâncias em que as palavras foram proferidas fossem apropriadas. Temos, então, a existência de um contexto situacional externo e comum aos interlocutores - Aríston e Ageto. A concepção de um contexto comum talvez possa não proceder se considerarmos que Ageto prometeu "sem pensar", indicando um comportamento precipitado e o fato de que cada indivíduo apresenta um ambiente cognitivo constituído de forma individual. Por outro lado, é bastante razoável afirmar que, mesmo entre as mais diversas culturas humanas, sempre é possível constatar a existência de elementos comuns, o que geralmente faz com que, em uma interação, por mais diferentes que sejam os atuantes, haja pontos de contato e, dessa forma, a possibilidade de comunicação com a realização de atos de fala.

A partir daqui, temos o último ato de fala do trecho no qual "juramentos mútuos" realiza novamente uma ação: a condição de aceitação de ambos para a ação de jurar. $O$ falante e o ouvinte teriam conhecimentos em comum, o que permitiria ao segundo recuperar a intenção informativa do primeiro de forma precisa, através de um processo que mais se assemelharia à codificação e decodificação linguística. Entretanto, tal transferência literal de intenções e proposições entre interlocutores não é observada nas práticas enunciativas que se seguem, dando a entender que a comunicação ocorre muito mais de forma aproximada do que literal, podendo, algumas vezes, até mesmo falhar ou resultar em mal-entendidos. ${ }^{87}$

Retomemos a narrativa de Heródoto. Antes de decorridos dez meses da união, a exmulher de Ageto deu à luz a Demarato, tendo Aríston declarado: "Não pode ser meu". 88 Embora arrependido depois de suas palavras e convencido de que o filho era realmente seu,

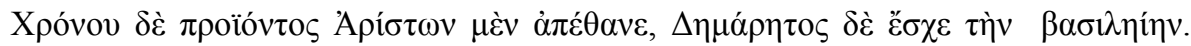

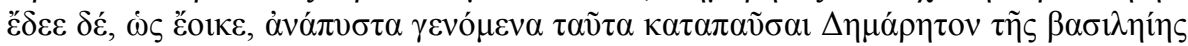

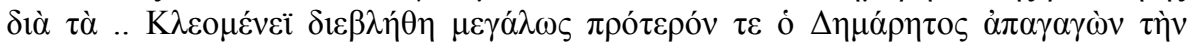

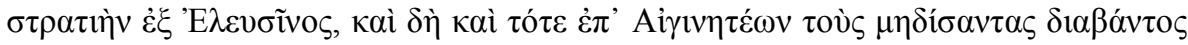
$\mathrm{K} \lambda \varepsilon \circ \mu \varepsilon \dot{v \varepsilon o \zeta . ~}$

Com o passar do tempo, Aríston faleceu e Demarato tomou a realeza. Mas estava no destino, segundo parece, que, quando se tornassem conhecidos, estes factos viessem a depor Demarato do trono. É que, a Cleómenes, Demarato tinha-se tornado particularmente odioso, primeiro por ter retirado o exército de Elêusis e, especialmente agora, quando da expedição que Cleómenes fizera contra os Eginetas, partidários dos Medos. (HERÓDOTO, VI, 64)

\footnotetext{
${ }^{87}$ Ageto não havia entendido que a própria esposa poderia estar incluída no acordo.

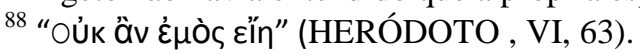


Como as discussões eram cada vez mais acaloradas acerca do direito à sucessão ao trono por Demarato, os espartanos resolveram consultar o oráculo de Delfos, que, tendo sua sacerdotisa sido subornada por cooperadores de Cleômenes, declarou não ser Demarato filho de Aríston:

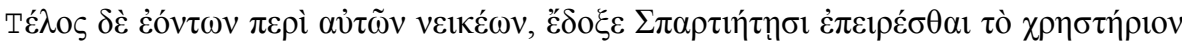

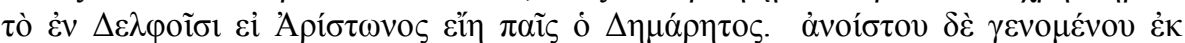

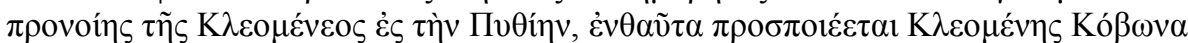

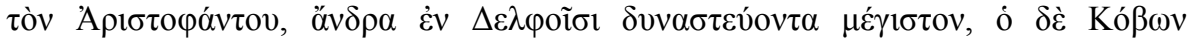

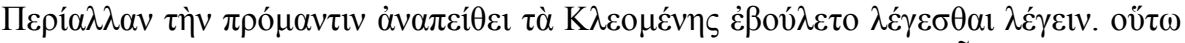

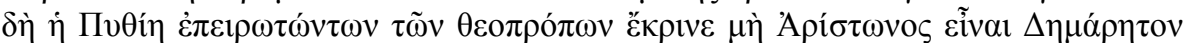

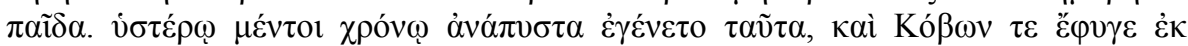

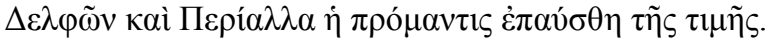

Por fim, já que o assunto levantava muita polémica, os Espartanos decidiram consultar o oráculo de Delfos, para saber se Demarato era na verdade filho de Aríston. Mas a ideia de se consultar a Pítia havia sido premeditada por Cleómenes, que, entretanto, tinha atraído a simpatia de Cóbon, filho de Aristofanto, e homem muito influente em Delfos. Cóbon persuadiu Periala, a profetisa, a declarar o que Cleómenes queria que se dissesse. E assim, em resposta à pergunta dos consulentes, a Pítia afirmou que Demarato não era filho de Aríston. Mais tare, contudo, esta manobra foi descoberta e Cóbon teve de fugir de Delfos; quanto à profetisa Periala, foi destituída de seu ministério. (HERÓDOTO, VI, 66)

\section{Assim sendo destronado,}

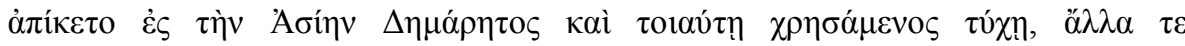

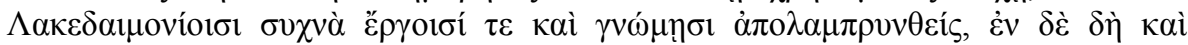

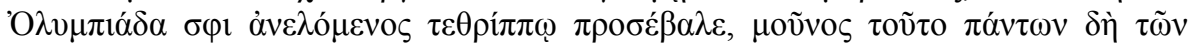

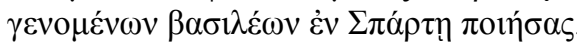

Foi desta forma que Demarato atingiu a Ásia, depois de ter passado tais infortúnios; ele que, em muitas circunstâncias, se tinha distinguido, entre os Espartanos, pelas obras e conselhos; em especial, tinha-lhes dado a honra de uma vitória olímpica, por ele arrebatada por uma quadriga, sendo o único, entre todos os reis de Esparta, a conseguir tal proeza. (HERÓDOTO, VI, 70)

\section{Por sua vez,}

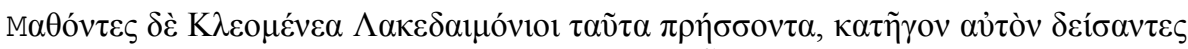

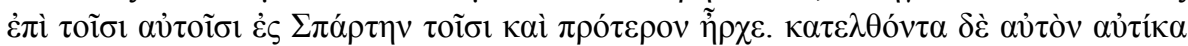

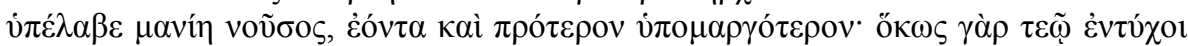

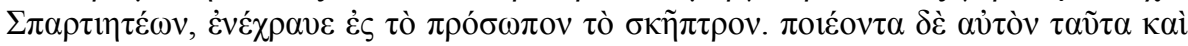

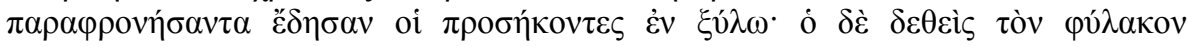

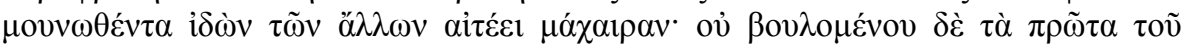

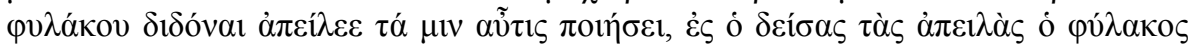

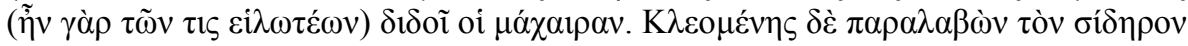

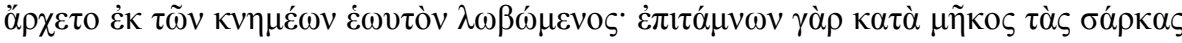

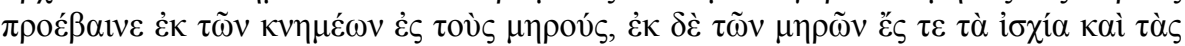

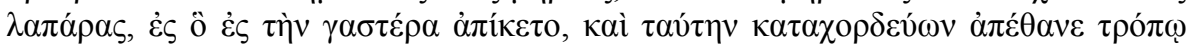

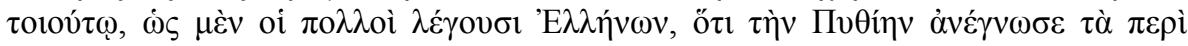




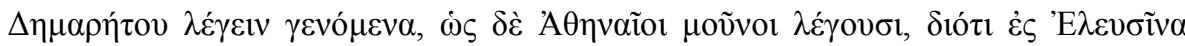

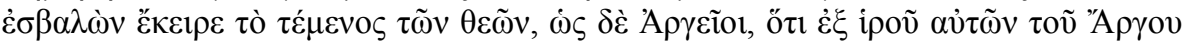

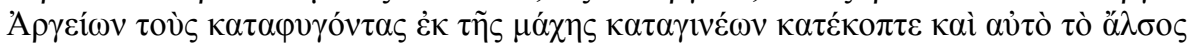

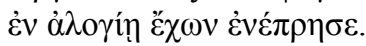

Mas os Lacedemónios, ao saberem que Cleómenes fazia estas manobras, tiveram receio e chamaram-no de novo a Esparta, com as mesmas condições com que antes tinha reinado. Mas, de regresso à pátria, foi tomado pela loucura, ele que já antes era de espírito um pouco desequilibrado: sempre que acontecia encontrar um Espartano, batia-lhe na cara com o bastão. Os parentes, ao verem que procedia daquela maneira e andava fora de si, prenderam-no numa paliçada de madeira. Mas ele, já preso, ao ver que apenas um homem o guardava, afastado dos colegas, pediu-lhe um punhal. Como, de inicio, o guarda não lho quisesse dar, ele ameaçou-o com o que o faria depois de se libertar, até que, receoso das ameaças, o guarda - que, na verdade, era um hilota - lhe entregou o punhal. Cleómenes, assim que agarrou na arma, desatou a golpear-se, começando pelas canelas. Fazendo incisões na carne em sentido longitudinal, cortava desde as canelas às coxas, das coxas aos quadris e aos flancos, até que, chegando ao ventre, o retalhou, vindo a morrer dessa maneira. Pelo que diz a maior parte dos Gregos, isto aconteceu por ele ter industriado a Pítia sobre a forma de se pronunciar a respeito de Demarato; pelo que afirmam, sozinhos, os Atenienses, foi por ele, ao atacar Elêusis, ter saqueado o santuário das duas deusas, quanto aos Argivos, foi por ele ter feito sair do santuário do herói Argos os Argivos que tinhas escapado à batalha, assassinando-os e, sem fazer qualquer caso do bosque sagrado, $\mathrm{o}$ ter incendiado. (HERÓDOTO, VI, 75)

Esta narrativa da morte de Cleômenes parece-nos a própria descrição da "morte em cena" de uma personagem da tragédia. ${ }^{89}$ No dizer de Carmen Isabel Soares,

Contrariando a acusação que já lhe foi feita de atribuir pouco interesse à descrição do derramamento de sangue propriamente dito, atentemos no modo como o autor rompe com as normas do decorum trágico (naturalmente incompatíveis com os princípios de realismo inerentes a um relato que se quer histórico), dando lugar a uma impressionante cena de "morte ao vivo". (2003, p. 451-452)

De acordo com Lateiner, heróis e vilões podem sorrir, mas somente os "bons moços" sempre sorriem e o sorriso deles pode conduzir à afeição, ao espírito conciliatório ou a uma consciência de conhecimento ou poder superior (1987, p. 86). A rivalidade entre Demarato e Cleômenes advém, na verdade, de gerações anteriores a eles e o primeiro concretiza-se como o "bom moço" porque sorri seu sorriso de morte por último e para sempre com a loucura e o suicídio de Cleômenes, demonstrando sua consciência de conhecimento e poder superior.

$\mathrm{Na}$ verdade, o riso e os que riem em Heródoto sugerem não um prazer inocente e uma alegria benigna, mas arrogância e autodesilusão (LATEINER, 1987, p. 95). No trecho acima transcrito, ${ }^{90}$ o narrador informa que os atenienses diziam ter sido a morte de Cleômenes castigo pelo suborno e pelo corte das árvores, por não ter respeitado os suplicantes do

\footnotetext{
${ }^{89} \mathrm{Na}$ verdade, como na tragédia, a morte não se dá em cena no momento instantâneo de sua ocorrência. É Heródoto, como o mensageiro trágico, quem reporta à audiência grega a ação de morrer e/ou de matar que está fora das vistas do espectador. Discorreremos mais sobre o assunto no próximo trecho sobre o lógos de Ciro.

${ }^{90}$ HERÓDOTO, VI, 75.
} 
santuário e pelo incêndio dos bosques sagrados. ${ }^{91}$ Essa informação marca a postura de Heródoto - e, segundo ele, dos atenienses - contra Cleômenes, numa espécie de vingança velada e prazerosa. O tirano tinha um comportamento completamente abusivo e o riso discreto, dissimulado e sardônico, portanto, não é só de Demarato, mas dos gregos. O caráter de Cleômenes, previamente delineado por um comportamento não-verbal desmedido, descrito por Heródoto, prepara a construção desse riso para o leitor.

Ressaltamos que esse sorriso é, contudo, atribuído à personagem de Demarato e oferecido como possibilidade para o próprio leitor, isto é, um escárnio, um gesto de morte que se atribui a esta personagem e que é também a ação do próprio leitor com o desfecho da história. Considerando que o comportamento não-verbal pode substituir, duplicar ou complementar a linguagem (LATEINER, 1998), verificamos que o público das Histórias pode captar e/ou inferir o sorriso sardônico a partir da leitura dos comportamentos não-verbais dos dois reis lacedemônios, ainda que Demarato não estivesse presente ao fim e à loucura de Cleômenes. Na verdade, considerando que, certamente, o público não apareça na narrativa, aparecem, sim, a reação dos helenos e do próprio Heródoto:

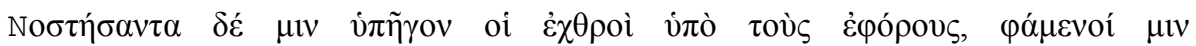

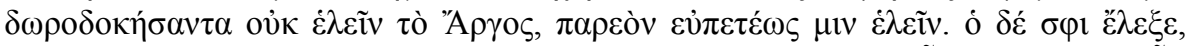

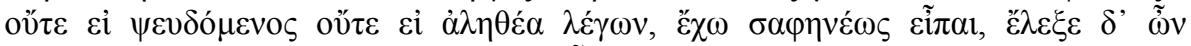

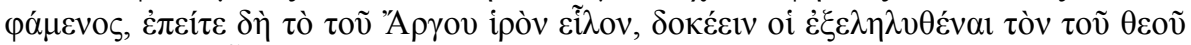

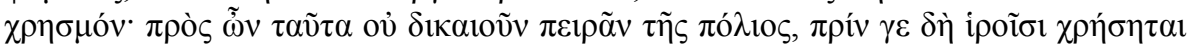

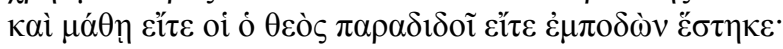

Mas, uma vez de regresso, os inimigos levaram-no até junto dos éforos, afirmando
que ele não tinha tomado Argos, quando o poderia ter feito facilmente, por se ter
deixado corromper com presentes. Este, porém, respondeu-lhes - se estava a mentir
ou a dizer a verdade, não o posso afirmar com certeza - objectando que, quando
tomou o santuário de Argos, lhe pareceu que se tinha cumprido o oráculo do deus.
Por essa razão, não lhe parecera correcto avançar sobre a cidade antes de ter
procedido a uma consulta, com sacrifícios, e saber se a divindade a entregava ou
punha obstáculos à empresa. (HERÓDOTO, VI, 82)

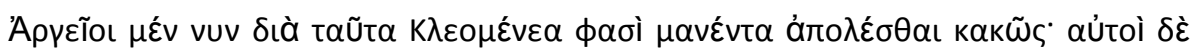

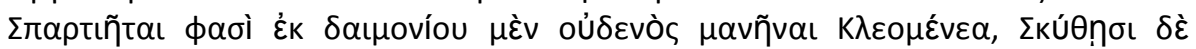

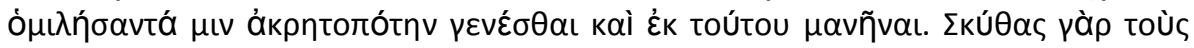

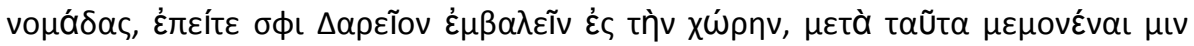

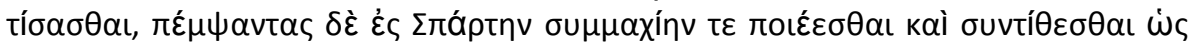

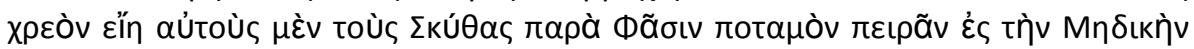

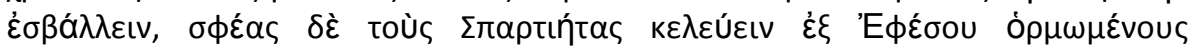

\footnotetext{
91 “Alguns dos episódios da vida do monarca lacedemônio permitem explicar a sua morte como pena directa da anomia religiosa (...). As várias versões apresentadas para os motivos que aos olhos dos contemporâneos tornaram o suicídio uma vingança divina mais não são do que a prova de uma impiedade (asébeia) tresloucada. A todas elas subjaz o denominador comum do desrespeito por leis sagradas básicas. Na opinião mais corrente (...), Cleômenes pagava por ter subornado o oráculo de Delfos, convencendo a Pítia a negar que Demarato fosse filho de Aríston e portanto o legítimo herdeiro, na linha dos Euripôntidas, do trono de Esparta" (SOARES, 2003, p. 452-453).
} 


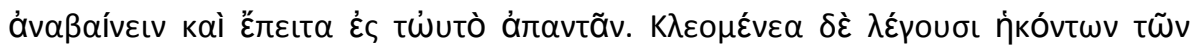

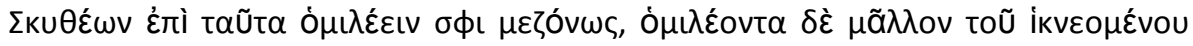

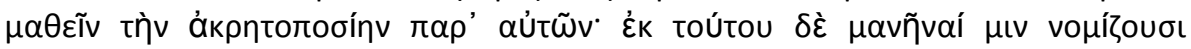

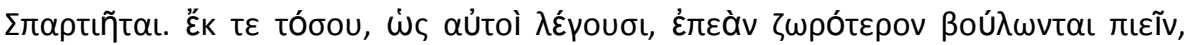

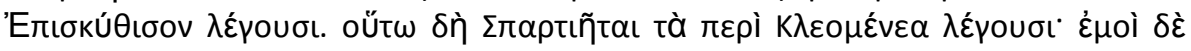

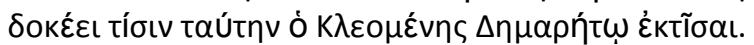

Os Argivos, portanto, dizem que foi por estes motivos que Cleómenes ficou louco e morreu de maneira miserável; contudo, os próprios espartanos afirmam que Cleómenes não enlouqueceu por causa de nenhuma divindade, mas sim que, por ter convivido com s Citas, se habituara a beber vinho puro, sendo essa a causa de sua loucura. De facto, os Citas nómadas, depois que Dario invadiu o seu país, desejavam vivamente vingar-se dele; enviaram, portanto, a Esparta legados a fim de firmarem uma aliança, nos seguintes termos: que eles próprios, os Citas, deveriam tentar penetrar no território dos Medos subindo ao longo do rio Fásis, enquanto convidavam os Espartanos a avançarem para o interior a partir de Éfeso, juntando-se depois num ponto determinado. Afirmam, assim, de Cleómenes que, quando os Citas vieram com este projecto, ele os frequentava muito e, visitando-os mais do que seria conveniente, aprendeu com eles a beber vinho puro. Para os espartanos, foi por este motivo que ele enlouqueceu. Desde então - pelo que eles afirmam - quando pretendem beber vinho sem mistura, dizem "à maneira dos Citas". É, por conseguinte, nestes termos que os Espartanos contam a história de Cleómenes; quanto a mim, parece-me que foi uma expiação em paga do seu comportamento com Demarato. (HERÓDOTO, VI, 84)

No segundo trecho podemos perceber que o narrador amplia o riso, incluindo os espartanos, que, por sua vez, apontam no excesso de bebida um comportamento não-verbal. Os movimentos corporais e outros comportamentos não-verbais, portanto, oferecem uma técnica de descrição que envolve a empatia dos outros, dando uma técnica de persuasão que é argumentativa. Na verdade, não dirigido por padrões culturais - sistemas organizados de símbolos significantes - o comportamento do homem seria virtualmente ingovernável, um simples caos de atos sem sentido e de explosões emocionais, e sua experiência não teria praticamente qualquer forma. A argumentação é de que a comunicação envolve processos de formação de ideias e respostas emocionais e também processos de interação social; o comportamento não-verbal facilita a produção do discurso (LATEINER, 1998).

Sendo assim, os comportamentos não-verbais proporcionam ao leitor insights psicológicos que, não possuindo, entretanto, evidência imediata, o levam à compreensão dos padrões de comportamento das personagens. Segundo Lateiner, o momento vital de uma história pode ser indicado por um gesto significativo ou um som não-verbal, concentrando a atenção da audiência e escalando as intensidades das emoções (1987).

Quando lemos palavras "bem amarradas" numa página, nós (re)imaginamos interlocutores com todas as suas pistas e sinais corporais. Dessa forma, com "vozes", nós mentalmente recriamos tons e timbres vocálicos e, com "gestos", recriamos movimentos. Cruciais para o repertório comunicativo, os gestos geralmente são um complemento da mensagem verbal e algumas vezes fornecem significado completo à comunicação pela 
interação entre si mesmos, podendo mesmo marcar estágios avançados numa trama (LATEINER, 1998). Ou seja, as personagens podem ser compreendidas lendo-se cuidadosamente suas palavras e o modo como são ditas, dando-se atenção à forma como o autor descreve sua maneira de respirar, suspirar, tamborilar os dedos, mexer os pés ou mudar de posição nos cenários em relação aos objetos e a outras personagens.

Lateiner sublinha que a demonstração de Heródoto sobre sua pesquisa engloba a linguagem corporal e oferece uma variedade de tipos de informação bem como de tentações retóricas e ficcionais. Afirma, ainda, que a comunicação não-verbal, relatada com detalhes, como se proveniente de uma testemunha ocular, revela dramaticamente pensamentos, emoções e ações nas Histórias, quando relatos de discurso e ações intencionais são dados inadequadamente (LATEINER, 1987).

Nossa argumentação é a de que a todo o momento as personagens em Heródoto nos dão ou deixam pistas de quem realmente são e o que suas palavras de fato querem dizer. De fato, através de suas vestimentas, conduta, aspecto, palavras e associações, elas expressam a imagem que escolheram para si próprias e a audiência pode ser mais, ou menos, afetada (LATEINER, 1998). Sendo assim, nossa asserção é a de que, sendo o sorriso sardônico predominantemente cultural, ele representa, em Heródoto, uma forma de comunicação dramática entre a personagem - Demarato - e o público.

Entre os planos básicos para nossa vida, como, por exemplo, a capacidade de falar num certo tom de voz ou de sorrir enigmaticamente numa delicada situação social, existe um conjunto complexo de símbolos significantes. Nossas ideias, nossos valores, nossos atos, até mesmo nossas emoções são produtos culturais e as pessoas que compartilham algumas características pensam e agem de maneira semelhante. A partir disso, afirmamos que os sinais não-verbais têm as funções específicas de regular e encadear as interações sociais e de expressar emoções e atitudes interpessoais.

Não ignoramos que há certa inconsistência nos seres/personagens humanos. Nunca poderemos saber precisamente o que é que os que nos ouvem/leem/assistem compreendem do que nós dizemos, porque os mundos referenciais deles serão sempre diferentes dos nossos. Porém, apesar dessa indeterminação, o poder da mensagem transmitida é enorme. Consideramos, ainda, que ninguém é inteiramente inconsistente. Embora a maioria dos indivíduos seja o resultado de uma confusão de pensamentos e valores que frequentemente entram em conflito, percebemos que padrões de comportamento emergem dessas inconsistências aparentes e consideramos que esses padrões tornam-se mais formados e significativos nas personagens literárias, por estarem elas atadas na escrita de um autor. E, a 
partir do momento que assumimos que há padrões formados, verificamos que o leitor pode identificá-los e, pela identificação, conseguirá entender as personagens e "prever" o comportamento delas, como acontece no desencadeamento de ações encenadas no palco.

Não obstante reconheçamos que nas relações humanas comuns e na interação dos atores e do público, o emissário e o receptor de um sinal estejam mutuamente implicados e que, na literatura, o leitor observa e permanece à distância, pois a externalização da emoção através de numerosos e simultâneos sinais que utilizamos em nossa vida diária sofre um severo encurtamento na linguagem escrita (LATEINER, 1987), acreditamos que os sinais não-verbais mantêm-se como elo que liga as ações das personagens à reação do leitor. Isto é, em todo livro podemos ver aquilo que pode ser apreendido a partir do modo como uma determinada figura se apresenta, fala e age - e, assim, temos a (des)medida do sentimento, olhar, sorriso etc. que o ato de outrem provoca na história e em nós mesmos.

Nas Histórias, quando Cleômenes "se rende" à loucura e comete suicídio rasgando o próprio corpo com uma lança, o sorriso de Demarato é o sorriso do próprio público que, ciente do enredo, reage com aquilo que é indiscursável, o elemento que ecoa um universo de reações onde as palavras não funcionam: o "sorriso sardônico" é a atitude e a atitude é o momento crítico, o clímax da cena. Como ocorre na maioria dos casos de uma "cena de anúncio", o discurso do mensageiro, aqui, coincide com a catástrofe que é preparada minuciosamente no decorrer da tragédia. O público, influenciado por numerosas indicações ao longo da narrativa, sabe, em linhas gerais, como e quando se poderá dar o desenvolvimento da ação dramática (GREGORIO, 1967, p. 9).

No clímax do "episódio" entre os reis de Esparta - o suicídio de Cleômenes - o padrão de comportamento das personagens já foi completado pelo público. Eles não veem mais, então, a situação geral, mas as especificidades do comportamento e das ações de cada um. A revelação gradual dos atos de Cleômenes é o que leva ao sorriso sardônico de Demarato, ${ }^{92}$ no ponto culminante de relação entre ambos, sob o olhar do espectador. E, é importante notar, a audiência não precisa "trabalhar" para construir o padrão que revela a natureza das personagens. Heródoto faz com que tais padrões revelem-se diante de nossos olhos pela utilização da linguagem não verbalizada. Para isso, recorre primeiro à coerência, que atribui a suas personagens formas de pensar e reagir bastante semelhantes às suas; e, depois, recorre à

\footnotetext{
${ }^{92}$ Dizer que Demarato tem um sorriso sardônico em relação à morte de Cleômenes, no nosso entender, não quer dizer que Heródoto o tenha desrespeitado em sua caracterização. De fato, Demarato não é apresentado tripudiando Cleômenes. Acreditamos que, porém, a partir de todas as atitudes que o tirano havia tomado contra ele, este sorriso pode ser subentendido pelo leitor. Consideramos, ainda, os comentários e ações dos helenos que, em grande parte das vezes, não são respeitosos e que também podem reforçar o riso sardônico das personagens.
} 
correspondência segundo a qual o mundo de suas personagens deve ser muito parecido com o mundo que ele próprio conhece.

O momento de crise e clímax proporcionado pelo suicídio ${ }^{93}$ do rei lacedemônio é exemplo claro, então, de situação na qual a linguagem corporal tem extraordinário efeito na ação que fala mais alto que as palavras. Tão logo a tensão e a emoção do momento tenham se descarregado na palavra ou na imagem, enceta-se, em certa medida, uma peripécia do espírito. O riso desabrocha na conformação da linguagem. O que torna esta história trágica é o mesmo que a torna cômica. O comportamento não-verbal aparece-nos como uma espécie de poder que a linguagem exerce sobre o pensamento das personagens e do público. A palavra aparece, então, como ponto principal para contar a história.

$\mathrm{Na}$ verdade, o Heródoto mensageiro produz um entendimento imediato, dispondo os elementos do fato narrado de acordo com sua própria fantasia. Como mensageiro, então, ele profere suas palavras tendo a possibilidade de ostentar toda a sua capacidade interpretativa, fazendo com que o público entenda o particular narrado através da aproximação, a maior possível, da imaginação com a realidade dos fatos (GREGORIO, 1967). Ao anunciar os acontecimentos acerca da história dos reis espartanos, nosso autor pode ostentar sua capacidade de imitação dos gestos humanos como forma característica de levar o público ao entendimento dos acontecimentos e, para além das ações, dos sentimentos que as situações envolvem. Por isso, acreditamos que a audiência deste mensageiro não recebia as notícias narradas de forma impassível e em silêncio, mas participando com suas próprias emoções daquilo que a narrativa, carregada de detalhes, era capaz de proporcionar em termos de se poder vivenciar o ocorrido. Para o espectador, as sensações são criadas aos poucos, nas cenas narradas lentamente por Heródoto, enquanto, de fato, a ação é evocada de imediato, de acordo com a utilização de termos específicos acerca do gestual, da postura e da descrição de sentimentos das personagens envolvidas na narração.

A história e o diálogo entre o ouvinte e a narrativa aparecem com a incorporação do gesto à palavra: os comportamentos não-verbais são um instrumento do autor para causar a inferência na audiência de um sorriso sardônico por parte de Demarato, a partir da informação

\footnotetext{
${ }^{93}$ Lembrando que o ato de por termo à vida é uma atitude indicadora de um estado de demência, uma prova de insânia (mani \&a), como afirmavam os árgios (HERÓDOTO, VI, 84). Segundo Carmen Isabel Soares: "Para os habitantes de Argos, a irreverência deu-se para com o seu herói políade, na medida em que aquele não só se contentou em usar do dolo para fazer sair os suplicantes do recinto sagrado, massacrando-os em seguida, como agravou a sua culpa em ordenar o incêndio do bosque (...), donde resultou a cremação em vida dos que não saíram sob a falsa promessa de já ter sido pago o resgate e de estarem salvos de quaisquer castigos. E é aqui, na justificação dos Argivos, que encontramos a confirmação de que a ideia de que a loucura conduzia os actos de Cleómenes muito antes de o episódio fatídico do suicídio. Em seu entender, a impiedade demonstrada só pode ser explicada pela ausência de razão (...)" (2003, p. 454-455).
} 
de que uma personagem, no cume de sua prosperidade - Cleômenes - perde todo o sentido de sua fragilidade humana e da implacabilidade dos deuses, praticando atos de loucura marcados pela u3briv, isto é, agindo de acordo com uma desmedida, em ações, fatos e circunstâncias decisivos, na construção de um percurso de u ( (bristh\&V em que comete faltas que só podem ser resgatadas com a própria vida do insolente.

Aos motivos da cegueira e da aprendizagem pelo sofrimento ${ }^{94}$ somam-se, agora, o do erro (a (marti\&a)/compensação e da impiedade como um corolário formado na multividência grega em geral, e na da tragédia em particular (SOARES, 2003, p. 441). Percebemos, aqui, então, que há em Heródoto um tema muito importante, o qual é dramático: a lei de ascensão e queda dos impérios e indivíduos, ${ }^{95}$ isto é, um tema que envolve os conceitos de u3briv e ne\&mesiv. Se u3briv significa insolência, excesso, impetuosidade e insulto, ne\&mesiv expressa a indignação pela injustiça. Estes dois termos, tomados conjuntamente, indicam que, se um homem é insolente, ele pagará pelo seu ato de alguma forma, algum dia (GREENE, 1961, p. 481). Segundo David Greene,

\begin{abstract}
A hýbris, em Heródoto, é um conceito dramático. Seu efeito em nós, leitores, é o de conscientizar acerca do senso de inexorabilidade da causa que experimentamos no teatro (...). Ela é um estado da mente no qual o homem pensa mais que pensamentos humanos e depois os traduz em ação. ${ }^{96}$ (1961, p. 487. Tradução nossa)
\end{abstract}

São as associações dos leitores, surgidas da concatenação da narrativa produzida, que proporcionam o tom da comunicação não-verbal, sublinhando os momentos críticos e dando acesso rápido aos estados de emoção que os mesmos leitores têm e/ou atribuem à personagem lida. O comportamento não-verbal geralmente fornece um feedback interno, que conta aos participantes e à audiência como eles devem reagir em determinadas situações (LATEINER,

\footnotetext{
${ }^{94}$ Presentes no lógos anterior.

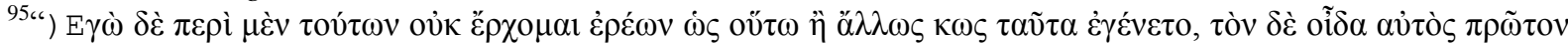

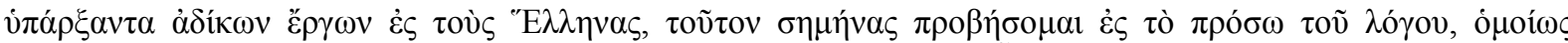

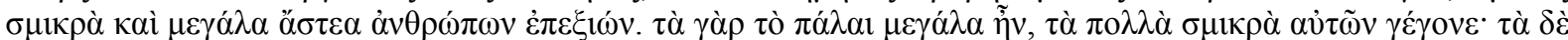

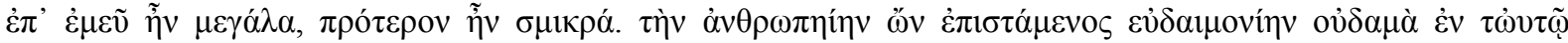

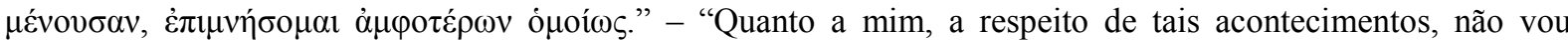
afirmar que as coisas se passaram assim ou de outra maneira, mas, depois de assinalar aquele que eu próprio sei ter sido o primeiro a comete actos injustos contra os Helenos, avançarei na narrativa, examinando indistintamente as pequenas e as grandes cidades dos homens. Das que antigamente eram grandes, muitas delas tornam-se pequenas, enquanto as que no meu tempo são grandes, eram primeiro pequenas. Persuadido de que a felicidade humana nunca permanece firme no mesmo ponto, mencionarei por igual umas e outras" (HERÓDOTO, I, 5).

96 "Hybris, in Herodotus, is a dramatic concept. Its effect on us, the readers, is to awaken the sense of inexorability of cause which we experience in the theatre (...).It is a state of mind in which man thinks more than human thoughts and later translates them into act."
} 
1998). Observar Heródoto pela comunicação não-verbal de suas personagens pode tornar o invisível visível e ampliar nosso entendimento do mundo antigo e do próprio autor.

Heródoto usa uma espécie de composição teatral para explicitar as ações e emoções das personagens, tornando o mundo que narra uma grande cena através das marcas de teatralidade que distribui pelas atitudes cotidianas. Parece-nos que o escritor histórico assume a posição do espectador diante do qual o espetáculo se desenrola, isto é, coloca-se na perspectiva do espectador e combina sua pesquisa com dados acurados com inteligibilidade e persuasão, de forma que somente será ouvido se responder aos anseios e expectativas de sua audiência (LATEINER, 1987).

Sob a perspectiva de que sua forma narrativa aproxima seus lógoi de cenas de anúncio, observamos que, da mesma forma que o mensageiro deveria proferir suas palavras respondendo às questões de outras personagens, principalmente do coro, (GREGORIO, 1967, p. 35), Heródoto deveria construir um discurso que contivesse indícios de comportamento das personagens envolvidas, os quais respondessem aos anseios do público grego. Nesse ponto, o qw=ma pode funcionar como critério de classificação, levando o relato das cenas daquilo que era menos extraordinário ao que era mais extraordinário. Esta manipulação do qw=ma compete apenas ao narrador, que a utiliza em função do destinatário: "a escala se organiza de acordo com o que é visto implicitamente como extraordinário, ou como mais e mais extraordinário, do ponto de vista de um 'nós' (eu e vocês). Obedece-se portanto ao ouvido do público" (HARTOG, 1999, p. 247).

\subsection{O mensageiro e o lógos de Ciro}

As origens de Ciro são narradas em Heródoto a partir dos presságios nos sonhos de Astíages, da dinastia dos medas, sobre uma inundação e uma videira:

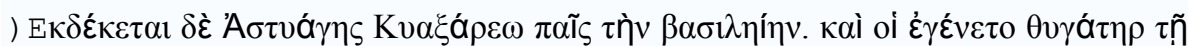

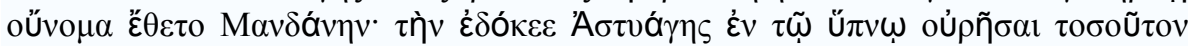

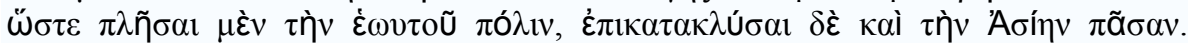

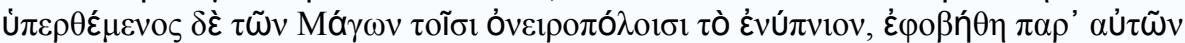

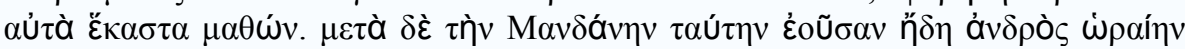

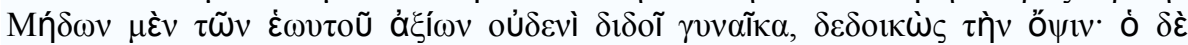

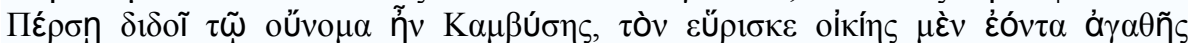

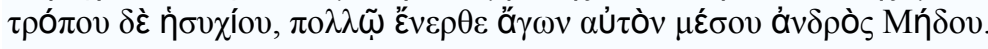


Sucedeu-lhe (Ciaxares), no trono, seu filho Astíages. Este tinha uma filha, a quem pôs o nome de Mandane. Em sonhos, o rei viu-a urinar com tal abundância que lhe inundou a cidade, e mesmo a Ásia inteira ficou submersa. Depois de submeter esta visão à consideração dos Magos que interpretavam sonhos, ficou apavorado quando lhe ouviu a explicação ponto por ponto. Mais tarde, quando Mandane chegou à idade de casar, não a deu por esposa a um Medo que fosse digno dela, com medo da visão. Foi dá-la a um persa, chamado Cambises, que sabia ser homem de boa família, de temperamento calmo, e que lhe parecia estar muito abaixo de um Medo da classe média. (HERÓDOTO, I, 107)

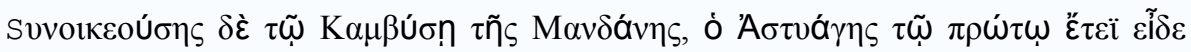

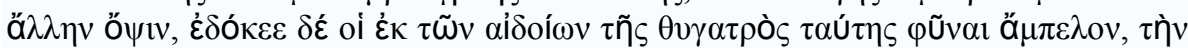

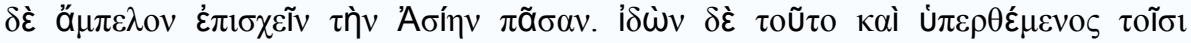

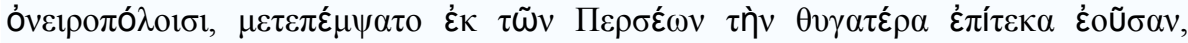

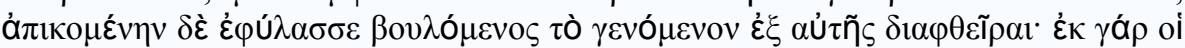

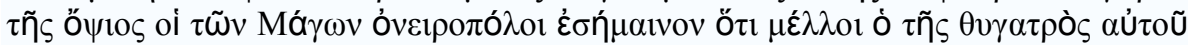

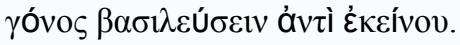

Logo no primeiro ano de casamento de Mandane com Cambises, Astíages teve outro sonho: parecia-lhe que, do sexo da filha, nascia uma vinha, e que esta vinha cobria toda a Ásia. Perante tal visão, e depois de consultar os intérpretes dos sonhos, mandou vir da Pérsia Mandane, que estava grávida. Quando chegou, pô-la sob vigilância na intenção de liquidar o filho que dela nascesse; é que, na sequência da tal visão, os Magos intérpretes de sonhos tinham-lhe profetizado que o descendente da filha havia de reinar em seu lugar. (HERÓDOTO, I, 108)

Astíages, tomando, então, o sonho como uma terrível profecia, ordenou a seu parente e aquele entre todos os medas em quem mais confiava, Hárpago, que assassinasse o jovem Ciro. Esse, temendo manchar o seu nome com um infanticídio e comovido com a beleza da criança, secretamente delegou essa incumbência a um pastor chamado Mitradates. No entanto, o pastor, tendo perdido recentemente seu próprio filho, decidiu escondê-lo e criá-lo como seu. Assim, vestiu o seu verdadeiro filho morto com as roupas do príncipe e expôs o corpo às feras do bosque, tal como lhe tinha sido ordenado fazer ao jovem Ciro, que foi criado como pastor.

Ainda segundo Heródoto, quando chegou aos dez anos de idade, rapidamente percebeu-se que Ciro não era filho de um pastor, pois o seu comportamento era demasiado nobre:

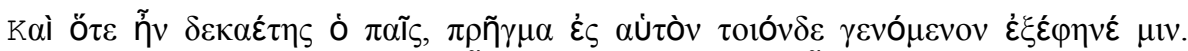

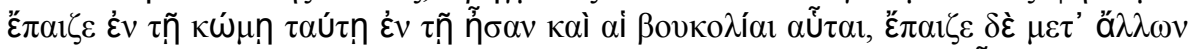

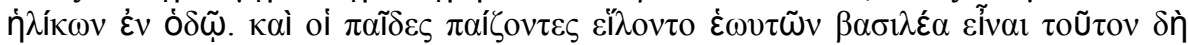

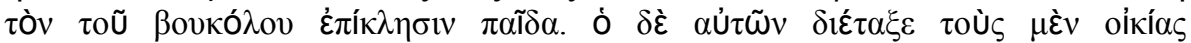

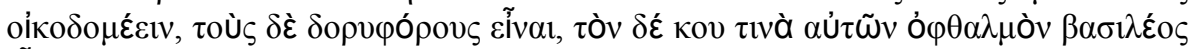

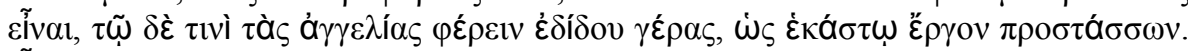

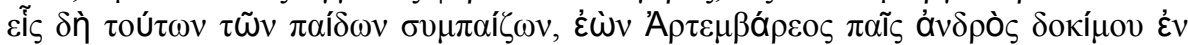

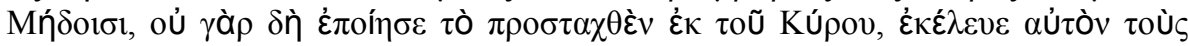

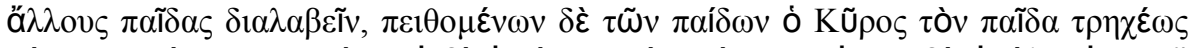

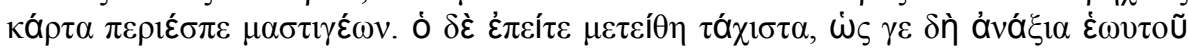

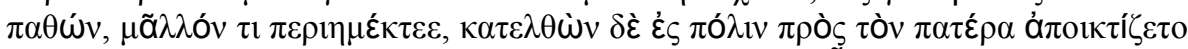

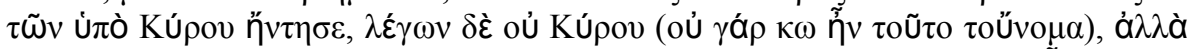

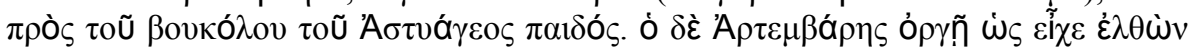

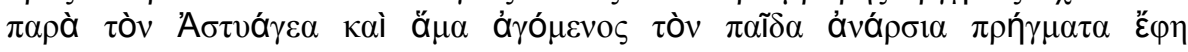




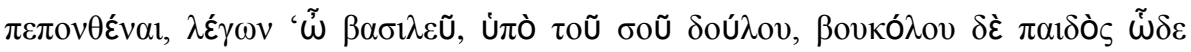

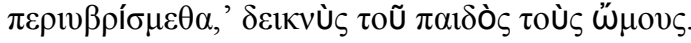

Quando o garato atingiu os dez anos, deu-se um episódio que se lhe revelou a identidade. Andava ele a brincar na aldeia, onde ficavam também os estábulos, entretido com outros miúdos da mesma idade, no meio da estrada. Na brincadeira, foi ele próprio, a quem chamavam o "filho do boieiro", que os garotos escolheram para seu rei. Por isso, ele seleccionou uns tantos para lhe construírem a casa, outros para seu corpo de guarda, um deles para ser o oho do rei, a outro encarregou-o de lhe trazer as mensagens, de forma que, a cada um, destinou uma tarefa. Porque um dos miúdos que tomava parte na brincadeira, filho de Artembares - homem considerado entre os Medos - não cumpriu a tarefa que lhe tinha sido atribuída por Ciro, este deu ordem aos outros que o prendessem. Eles obedeceram e Ciro tratou-o com dureza, à chicotada. Mal se viu solto, o miúdo ficou ainda mais furioso por ter sido tentado por uma forma indigna de sua condição. Desceu à cidade e foi queixar-se ao pai do tratamento que lhe dera Ciro. Ele não dizia "Ciro" (porque este não era ainda o nome que lhe davam), mas o "filho do boieiro de Astíages". Artembares, indignado, foi com o garoto procurar Astíages e declarou que o tinham ultrajado. "O rei", disse ele, "foi por um escravo teu, o filho do boieiro, que foi injuriados deste modo". E mostrava-lhe os ombros do rapaz. (HERÓDOTO, I, 114)

Astíages pode, dessa forma, encontrar-se com a criança e, imediatamente, apercebeuse do que se tinha passado ao dar-se conta de que o suposto filho do pastor parecia com ele próprio. Ordenou à Hárpago que lhe contasse o que se tinha passado; este, por sua vez, confessou que não havia matado o neto do rei, apesar do que lhe tinha sido ordenado. Ciro foi, então, recebido na corte e lhe foi permitido viver com os seus verdadeiros pais. A Hárpago, entretanto, ficou reservado, em troca, um cruel castigo pelo seu comportamento: Astíages convidou-o para um banquete em que, entre a comida, estava escondida a carne do seu próprio filho esquartejado; Hárpago apenas soube o que estava comendo quando levaram o último utensílio à mesa com a cabeça de seu filho:

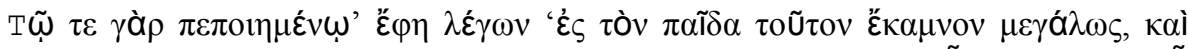

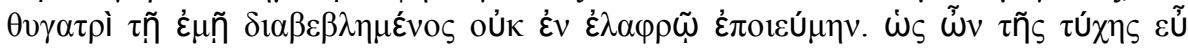

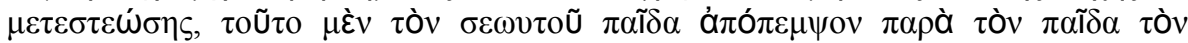

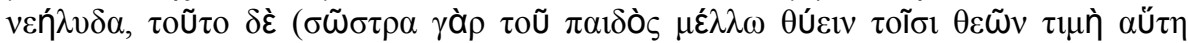

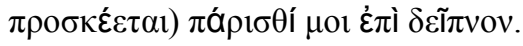

"É que", justificou (Astíages), "fiquei muito incomodado com o tratamento que se infligiu a esta criança; não me era fácil suportar o ressentimento da minha filha. Já que o destino tudo conduziu pelo melhor, manda o teu filho ao encontro do pequeno que acabamos de recuperar. Vou fazer aos deuses, a quem essa honra é devida, um sacrifício em acção de graças pela salvação do rapaz. Acompanha-me no jantar". (HERÓDOTO, I, 118)

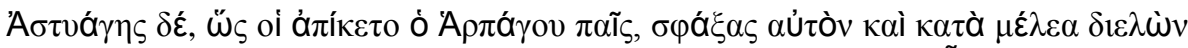

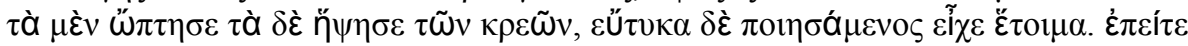

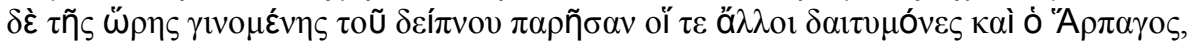

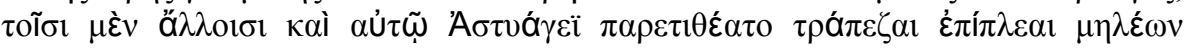

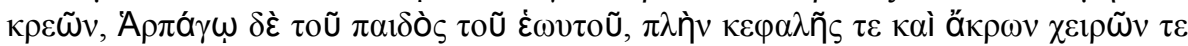

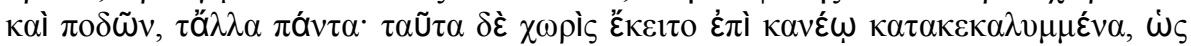

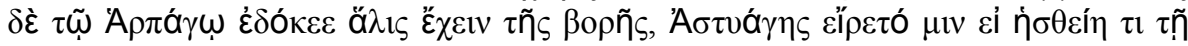




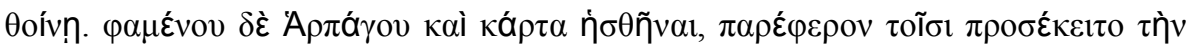

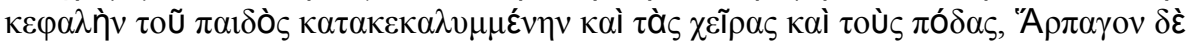

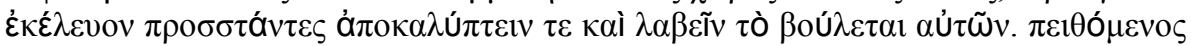

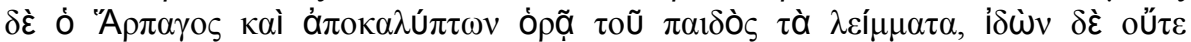

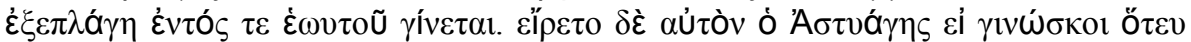

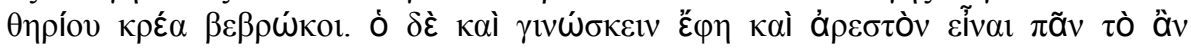

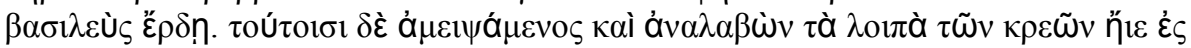

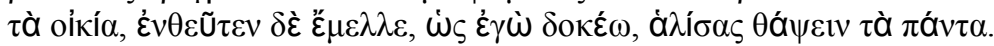

Astíages, quando o filho de Hárpago chegou, mandou-o degolar e esquartejar em pedaços; uma parte das carnes assou-a, outra cozeu-a, e pôs tudo pronto a servir. Quando chegou a hora do jantar e Hárpago e os outros convivas compareceram, a todos os presentes e ao próprio Astíages foram servidas mesas repletas de carne de carneiro, a Hárpago, o corpo inteiro do filho, menos a cabeça, mãos e pés; estas partes ficaram de lado, dentro de um cesto, e cobertas. Logo que Hárpago pareceu satisfeito, Astíages perguntou-lhe se tinha gostado do festim. Perante a resposta de que tinha gostado muito, aqueles que estavam incumbidos dessa missão trouxeram a cabeça, as mãos e os pés do rapaz, ainda cobertos; dirigiram-se a Hárpago e convidaram-no a destapar o cesto e a servir-se do que quisesse. Este obedeceu, e, ao destapá-lo, viu os restos do filho. Mas, perante o espectáculo, não se perturbou nem perdeu o auto-domínio. Astíages perguntou-lhe se sabia de que animal eram as carnes que tinha comido. Ele respondeu que sim e que aceitava tudo o que o rei fizesse. Depois desta resposta, pegou no resto das carnes e voltou para casa. Era sua intenção - julgo eu - juntar as sobras e dar-lhes sepultura. (HERÓDOTO, I, 119)

Heródoto narra que, desde então, Hárpago esteve a espera de uma oportunidade para se vingar da atrocidade cometida por Astíages. Quando Ciro tinha alcançado uma certa idade, Hárpago convenceu-o de que os medas estavam a preparar-se para para fazer uma rebelião ${ }^{97}$ contra o seu rei, que tinha se transformado num déspota. Em face disso, Ciro organizou uma aliança com as dez tribos persas. Em resposta, Astíages armou os medas e, cegado pelos deuses, elegeu Hárpago para comandante do seu exército. Durante a batalha, segundo uma fonte tardia, ${ }^{98}$ os medas aliaram-se com os persas. Este exército unificado marchou contra a capital Ecbatana e tomou a cidade de Astíages, que foi feito prisioneiro por Ciro.

Embora haja neste lógos elementos fantásticos, Heródoto utiliza-se de marcas de verossimilhança como técnica para transformar os fatos subjacentes ao relato que se poderia dizer mitológico sobre a juventude de Ciro no discurso realista e lógico da narração de sua

\footnotetext{
${ }^{97}$ Possivelmente, a causa mais forte para o início desta rebelião foi, de fato, a insatisfação com a política de Astíages. No século VI a.C. as tribos persas tornaram-se mais sedentárias e os seus líderes já não eram somente chefes tribais, começando, aos poucos, a se comportar como reis autênticos. Quando Astíages pretendeu castigar alguns dos outros chefes tribais a revolta foi inevitável.

${ }^{98}$ Estrabão da Amasia (63 a.C. ou 64 a.C. - c. 24 d.C). Historiador, geógrafo e filósofo grego ele foi o autor da monumental Geographia, um tratado de 17 livros contendo história e descrições de povos e locais de todo o mundo que lhe era conhecido à época, podendo ser vista como uma espécie de enciclopédia do início da Era

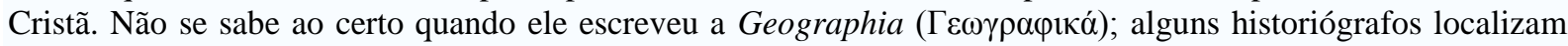
os primeiros esboços da obra durante o ano 7 d.C, outros no ano 18 d.C, mas a versão final data do reinado do imperador Tibério, uma vez que a morte de Juba, rei da Maurousia (23 d.C.) nela é mencionada. Com excepção do Livro VII, a obra chegou completa até nossos dias. Cerca de trinta manuscritos da Geographia ou de suas partes sobreviveram, quase todas cópias medievais de outras cópias, mas há fragmentos de rolos de papiro que foram provavelmente copiados por volta dos anos 100 a 300 d.C. A obra apresenta uma constante defesa do poeta Homero como fonte geográfica, mas não leva em conta Heródoto.
} 
história. Certamente os deuses têm algo a ver com os sonhos de Astíages ou é assim que ao leitor é dado assumir. Mas a justificativa de Hárpago para que não mate Ciro, na qual poderíamos esperar um espécie de sentença proferida pela "incorreção" do ato ou um apelo à vontade dos deuses, é da ordem do social, das leis e dos costumes:

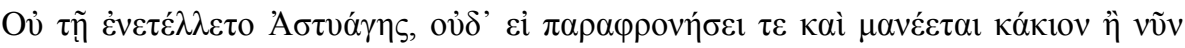

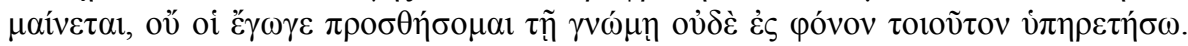

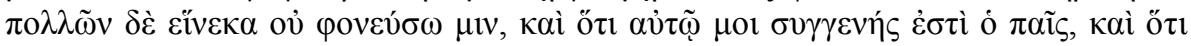

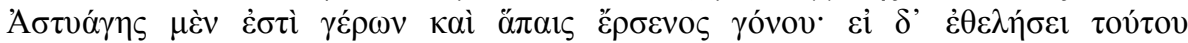

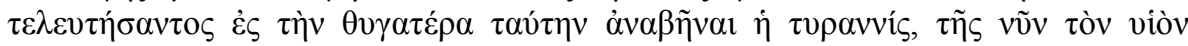

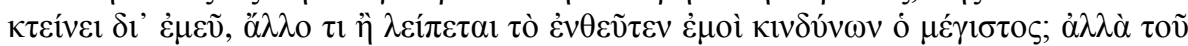

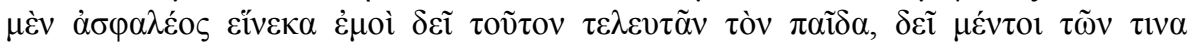

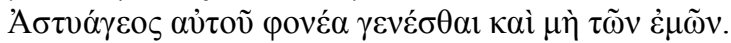

"Não vou cumprir as ordens de Astíages", respondeu. "Mesmo que ele estivesse transtornado e delirasse mais do que agora delira, não era eu que ia apoiar as suas decisões, em colaborar em semelhante crime. Sobram-me razões para não matar a criança: primeiro, porque é do meu sangue; depois, porque Astíages está velho e não tem descendente varão. Se ele decidir que, após a sua morte, o poder passa para as mãos da filha - aquela mesmo a quem agora quer liquidar o filho por meu intermédio -, o que me espera senão o maior dos perigos? Mas se, por outro lado, a minha segurança depende da morte desta criança, então terá de ser um dos homens de Astíages a executar o crime, não um dos meus". (HERÓDOTO, I, 109)
\end{abstract}

A socialização e a politização de muitos eventos dos lógoi sobre Ciro são, sem dúvida, uma técnica narrativa evidente em Heródoto, chamando a atenção do leitor para longe dos elementos mitológicos e fantásticos, para concentrá-la no mundo terreno e realista das personagens. $^{99}$

A história de Ciro é presumivelmente nova para a maioria da audiência grega, por isso o relato em si deveria cativar o interesse dos leitores e para isso contava a forma como o discurso era construído. Para isso, Heródoto recorre às marcas de verossimilhança, quando faz a narrativa do fantástico e, ao mesmo tempo, constrói o lógos de Ciro buscando ao máximo os fatos da história através das atitudes dos homens. Diferentemente da noção de verdade e de verdadeiro, entenderemos por verossímil, na ordem narrativa, aquilo que está ligado às possibilidades simbólicas dos homens e da história.

É interessante como, aqui, "a moral da história" não é de todo sobre a inevitabilidade do destino ou qualquer coisa que remeta, mesmo que remotamente, a algo semelhante. $\mathrm{Na}$ verdade, em harmonia com a ausência de referências aos deuses, quase não há indícios de predestinação: Astíages confronta diretamente seus oráculos e tenta lutar contra eles. Assim,

\footnotetext{
${ }^{99}$ Emprestando maior factualidade e historicidade à sua narrativa, por meio da integralidade e da amplitude das descrições, os detalhes tornam-se relevantes na construção do contexto histórico.
} 
por exemplo, somos informados de que Astíages comunicou os seus sonhos ${ }^{100}$ aos magos que se dedicavam a interpretações desse gênero. ${ }^{101}$

Provavelmente, a primera parte da história de Ciro é um conto inventado para explicar a realidade. Historicamente, ele foi rei da Pérsia entre 559 e 530 a.C. Na fase ascendente, Ciro é retratado como conquistador legítimo, sensato, honrado e que atua de modo justo. Assim que tomou o controle político, conquistou a Média de seu avô, dando liberdade a seu povo; depois, conquistou a Lídia, após ser atacado por Creso; conquistou também a Jônia, a qual não quis aliar-se a ele contra Creso. Nesse momento, Ciro é um modelo de força e virtude.

Depois, contudo, Ciro é retratado como conquistador que, no auge de suas conquistas, começa a transgredir o limite do comedimento, apressando sua queda. Na verdade, no relato das conquistas do rei persa, a conquista da Babilônia retrata o clímax e o início de seu descomedimento. A travessia do Gindo é o primeiro sinal da desmedida de suas atitudes. Sua cólera contra o rio e sua presunção de considerar a mulher como criatura frágil e inofensiva irão contribuir para sua queda:

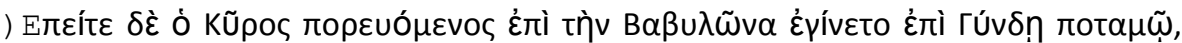

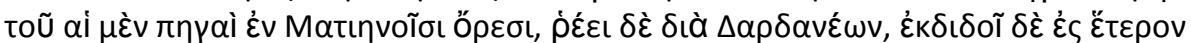

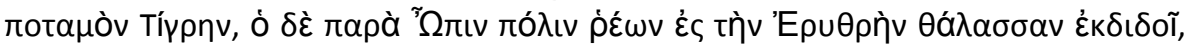

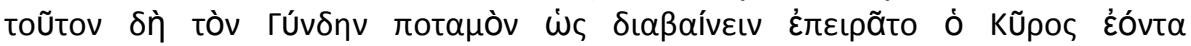

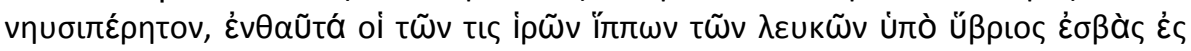

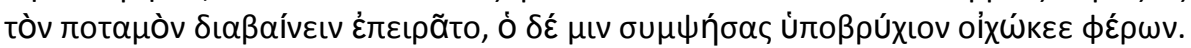

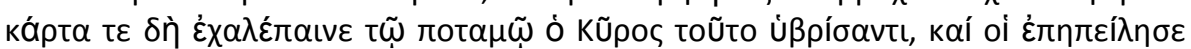

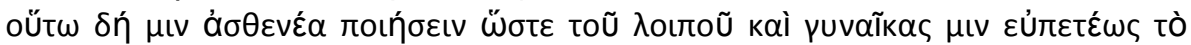

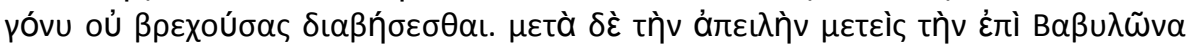

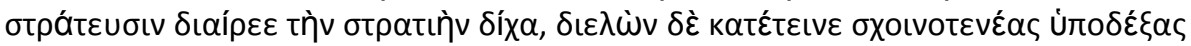

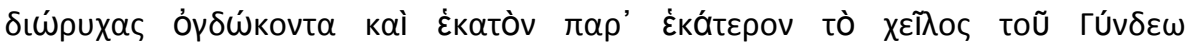

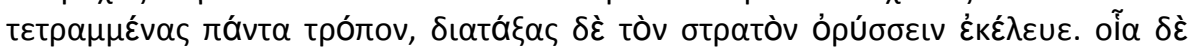

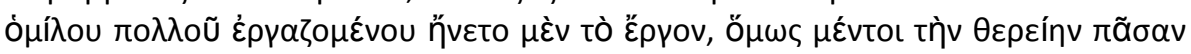

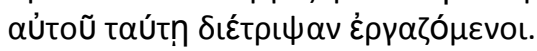

Quando Ciro, na sua marcha sobre Babilónia, chegou junto do rio Gindes - que nasce nas montanhas Macienas, corre através da Dardânia e deságua no Tigre; este,

\footnotetext{
${ }^{100}$ Sonhos já transcritos. Cf. p. 97.

101 Heródoto descreve os magos como originários de uma tribo dos medos e relata que eles atuavam como

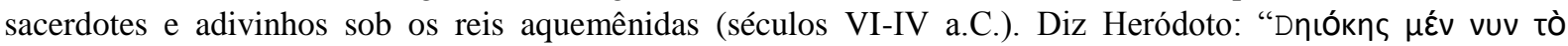

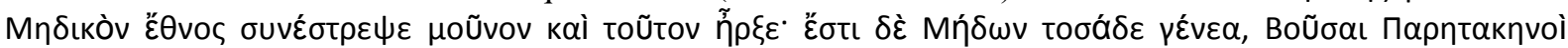

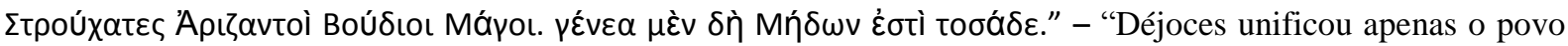
Medo, de que foi o soberano. Eis as tribos que o compunham: Busas, Paretacenos, Estrúcates, Arizantos, Búdios

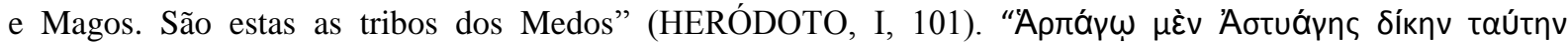

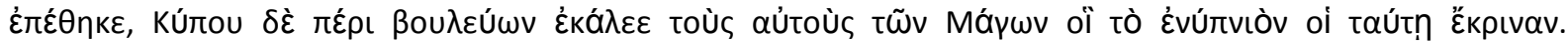

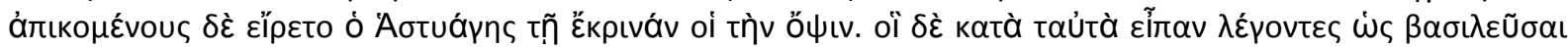

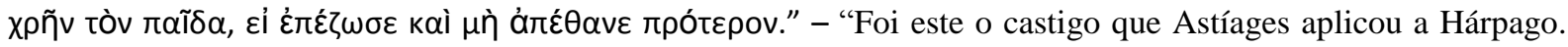
Preocupado com a atitude a tomar com relação a Ciro, chamou os mesmos Magos que lhe tinham interpretado o sonho da maneira atrás referida. Quando chegaram, o rei perguntou-lhes como é que lhe tinham explicado a visão que tivera. E eles repetiram as mesmas palavras, dizendo que o garoto teria forçosamente de reinar se sobrevivesse e não tivesse morrido antes" (HERÓDOTO, I, 120).
} 
por sua vez, corre perto da cidade de Ópis e desemboca no mar de Eritreia - ou seja, portanto, quando Ciro procurava atravessar o Gindes, que é navegável, um dos seus cavalos brancos sagrados excitou-se, entrou no rio e quis atravessá-lo; mas o caudal engoliu-o e arrastou-o consigo. Ciro ficou profundamente irritado com a afronta que o rio lhe tinha feito, e o ameaçou de o tornar tão fraco que, de futuro, até as mulheres o pudesse atravessar sem molhar sequer os joelhos. Proferida esta ameaça, desistiu do avanço sobre Babilónia; dividiu o exército em duas partes, dispô-las em filas, assinalando com cordas estivadas uma rede de cento e oitenta canais em cada uma das margens do Gindes, voltados em todos os sentidos. Depois de ter alinhado as tropas, deu-lhes ordens de cavarem o solo. Dado o número elevado de obreiros, esta tarefa foi levada a cabo; no entanto, ocupou-se nela o verão inteiro. (HERÓDOTO, I, 189)

O confronto na Babilônia é realizado, então, praticamente contra o rio - e também contra as obras de duas rainhas, Semíramis e Nitócris, as quais, no passado, haviam feito obras no rio para melhor atender à cidade. De fato, a Babilônia é tomada a despeito do rio e das rainhas.

Estes dois elementos - rio e rainha - contudo, voltarão a ocorrer na última campanha de Ciro - contra os massagetas. Não obstante esse relato não seja considerado relevante do ponto de vista da historiografia moderna, pois há quem duvide de sua veracidade, acreditamos que Heródoto o faça por incluir temas que lhe parecem importantes, tais como o da rainha vingativa (Tómiris), o da barreira líquida (o rio Araxes), o dos conselheiros, do nómos dos povos e da conclusão do lógos de Ciro com alusão aos elementos que lhe deram origem: o vinho no qual ele é "mergulhado" após sua morte. ${ }^{102}$

A narrativa de Heródoto sublinha maravilhosamente a ascensão ao poder e domínio das cidades por Ciro. Queremos, aqui, destacar que o texto das Histórias descreve que o rei persa sempre enviava à sua frente mensageiros que propusessem a paz para as cidades ameaçadas de destruição. Porém, sua agilidade em conquistar era tamanha que ocorria a Ciro chegar, muitas vezes, antes de seu mensageiro, tornando-se ele o próprio o seu alggelov:

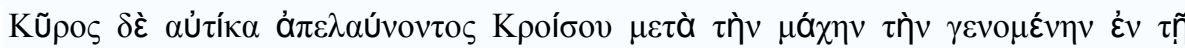

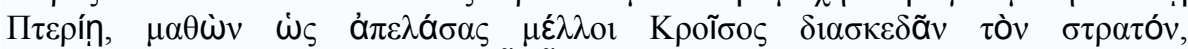

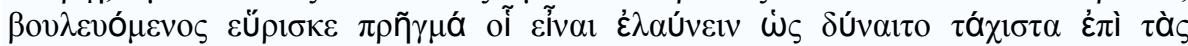

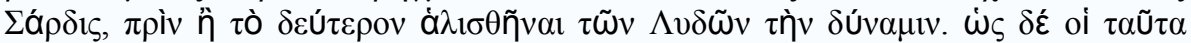

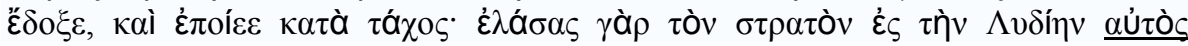

\footnotetext{
${ }^{102}$ Naquela ocasião a figura do rio como barreira líquida e da rainha Tómiris como rainha vingativa irão determinar a ruína de Ciro. O rei Persa, já sem sua lucidez inicial, precisa de conselhos e acolhe os de Creso. Ciro aceita conselhos daquele que no passado não soube aquilatar a situação. Creso propõem usar o no\&mov dos masságetas contra eles: como são um povo simples e sem luxo, se atraídos a um banquete de carne e vinho, logo perderão o controle e serão vencidos. Tómiris, rainha dos masságetas, torna-se a rainha vingativa quando seu filho se suicida após ter sido vencido e capturado com dolo e vinho. Como rainha vingativa, então, ela tem poder, mas este geralmente é menosprezado pelo elemento masculino opositor. Sua vingança, contudo, é inteligente e fria. Morto Ciro, Tómiris mergulha sua cabeça em um odre cheio de sangue e realiza sua vingança. É interessante relembrar a rainha de Candaules que também subestimada planejou e levou à execução o assassínio de seu marido como vingança.
} 


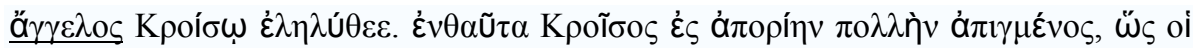

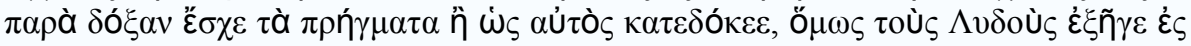
$\mu$ áxๆv.

Ciro, logo que Creso partira após a batalha travada em Ptéria, ao ter conhecimento que ele, terminado o regresso, tinha intenção de licenciar o exército, reflectiu e chegou à conclusão de que o objectivo era marchar contra Sardes o mais rapidamente possível, antes que de novo reunissem as forças dos Lídios. E, uma vez tomada esta resolução, executou-a sem detença: penetrou com o exército na Lídia e, da sua chegada, ele mesmo levou a notícia a Creso. (HERÓDOTO, I, 79. Grifo nosso)

Nesse entrecho, com sua velocidade em transmitir informações para aqueles que estão fora de seu domínio, Ciro é, na descrição de Heródoto, senhor e mensageiro - e as duas personagens fundem-se, significativa e ironicamente, em uma só.

O recurso à figura do mensageiro é mais um aspecto evidente da intenção dramática da estrutura do lógos de Ciro. Há, naturalmente, semelhanças evidentes entre passagens da história de Ciro e passagens das tragédias, como de As Bacantes, por exemplo. Heródoto, como o mensageiro das tragédias faz em relação a Penteu, anuncia e narra a morte do filho de Hárpago. Ele traz ao conhecimento de seu público aquilo que ocorreu fora de sua esfera visual, bem como da de outras personagens, não importando quão nefasto seja. ${ }^{103}$ Nas tragédias, seguindo as convenções do drama grego, não houve violência exibida no palco e, assim, a morte de Penteu é narrada por um mensageiro:

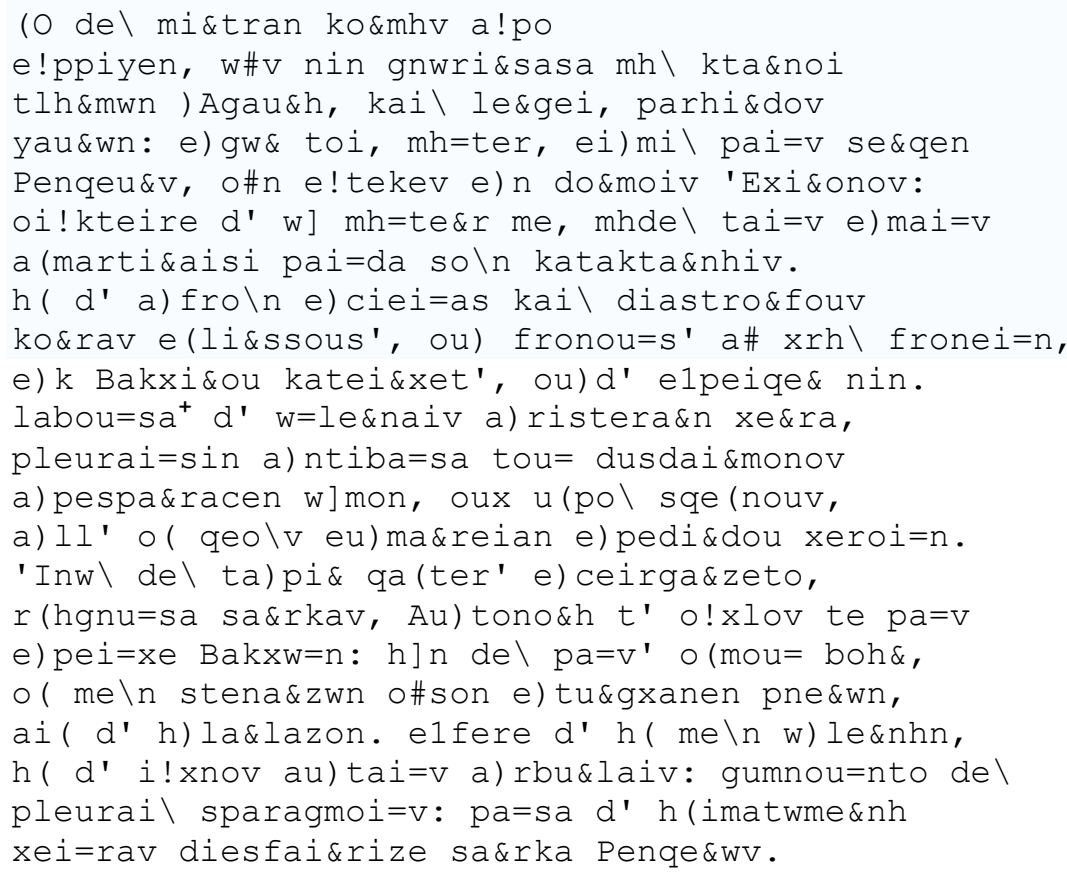

\footnotetext{
${ }^{103}$ Lembramos que Hárpago não presencia a morte do filho. De fato, só toma conhecimento dela quando recebe os restos da criança em um cesto.
} 


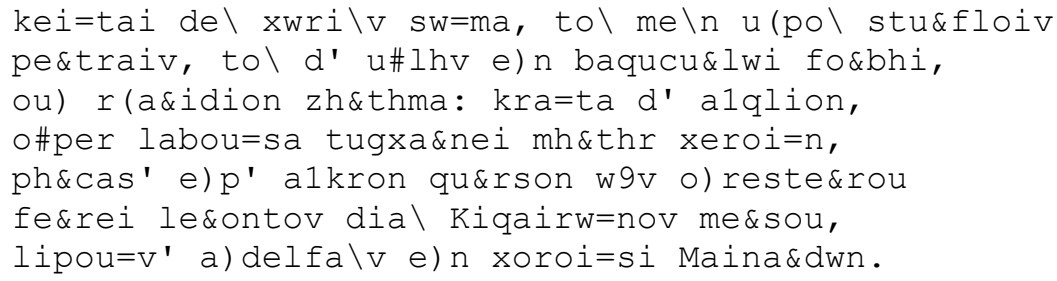

Este [Penteu], arrancando a mitra a custo de sua cabeça e ansioso por ser reconhecido logo pela mãe e salvo assim da morte a que ela o condenara, disse-lhe enquanto lhe acariciava o rosto: "Sou eu, querida mãe! Sou teu filho Penteu, que deste à luz no palácio do antigo Equíon! Ah! Mãe! Apieda-te de mim! Não sacrifiques teu filho para castigar as suas faltas!" Agave, pondo muita espuma pela boca e revirando os olhos desvairadamente, como se Baco a possuísse, não o ouviu. Ela prendeu com suas mãos o braço esquerdo do filho, e com um pé premindo um de seus flancos deslocou-lhe a espádua e arrancou-a, sem dúvida não com suas próprias forças mas com aquelas que lhe transmitia o próprio deus. Inó fez sobre o outro flanco a mesma coisa e lacerou as carnes do pobre Penteu enquanto Autônoe e as outras mulheres vinham trazer-lhe mais ajuda. Só se ouviam lamentações confusas e Penteu gemia nos momentos finais da luta contra a morte; ao mesmo tempo as três irmãs, gritando uníssonas, aceleraram o esquartejamento; uma logo arrancou do moribundo um de seus braços; outra um dos pés inda calçado na sandália, e as três tiraram de seus flancos lacerados as carnes palpitantes. Com as mãos sangrentas, como se disputassem um jogo de bola elas lançavam em todas as direções restos do corpo de Penteu; pedaços dele jaziam em vários lugares entre as rochas e até nos galhos altos das árvores frondosas, de onde seria dificílimo tirá-los.

Quanto à cabeça do desventurado, Agave tomou-a entre as mãos e conseguiu fincá-la sobre seu tirso; ela - coitada! - imaginava que era a cabeça de um leão, mostrando às Mênades pelos caminhos do Citéron seu troféu. (EURÍPIDES, As Bacantes, 1125-1143)

Nas Histórias, bem como no discurso do mensageiro na tragédia, há liberdade de descrição, ${ }^{104}$ na qual a palavra se apresenta como objeto de visão ou como espetáculo numa narrativa vívida. Vemos, portanto, a chacina do filho Hárpago por Astíages e, através da narrativa herodotiana, somos também testemunhas de suas consequências:

${ }^{104}$ Tal qual já discutimos acerca da morte de Cleômenes. 


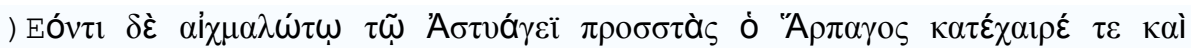

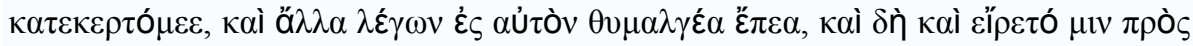

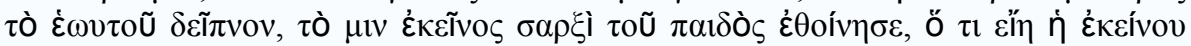

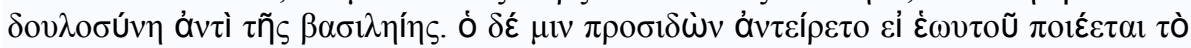

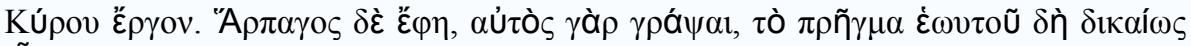

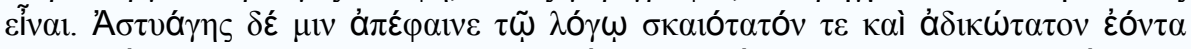

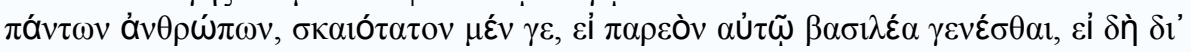

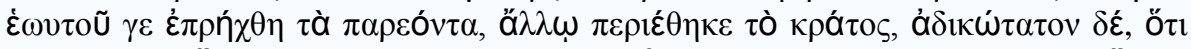

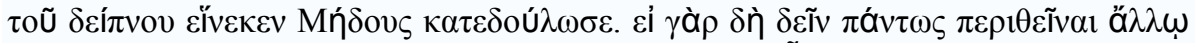

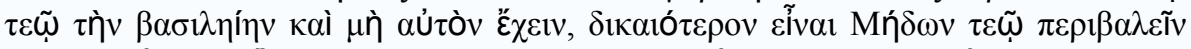

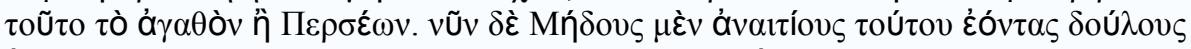

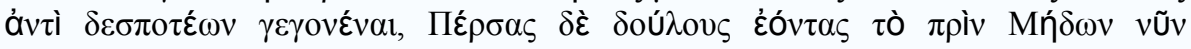

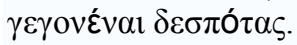

Na prisão, Hárpago veio ter com ele, exultante e sarcástico. Entre os vários insultos que lhe dirigiu, perguntou-lhe que tal lhe parecia, em troca do jantar que lhe tinha servido com carnes do filho, aquela mudança de soberano para escravo. O rei olhouo de frente e perguntou-lhe, por sua vez, se achava responsável pelo que Ciro fizera. Como resposta, Hárpago afirmou que, por lhe ter escrito, podia considerar, com justiça, essa empresa obra sua. Demonstrou-lhe o prisioneiro que ele era o cúmulo do fracasso e da vileza: do fracasso, porque, apesar de ter podido tornar-se rei, se de facto era obra sua toda aquela situação, tinha investido outro no poder; da vileza, porque, por causa do famoso jantar, tinha reduzido os medos à escravidão. E se era de todo necessário entregar a outro, que não ele próprio, a soberania, teria sido mais correcto atribuir esta honra a um Medo que a um Persa. É que assim, sem culpa nenhuma, os Medos passavam de senhores a vassalos, enquanto os Persas, outrora vassalos dos Medos, ascendiam agora a seus senhores. (HERÓDTO, I, 129)

Todos os dispositivos apresentados na fala de Astíages trazem à tona os preconceitos sociopolíticos que Heródoto traz consigo e sustenta a tese de Hayden White (1987) sobre o pressuposto de um sistema jurídico de uma história narrativa. Esse viés, no entanto, longe de tornar o trabalho mais subjetivo, acrescenta uma maior objetividade e veracidade em termos de um estudo da própria sociedade da qual o autor faz parte. Vemos às claras e bem definidas as normas que ele usa para medir as outras culturas, as quais, por sua vez, nos revelam o retrato histórico da Grécia Antiga.

O mundo dessas personagens, bem como de seu autor, é altamente político. Aqui, talvez, é o local no qual se encaixe melhor a tese de White (1987): devido ao tema central do conto de conflitos e lutas pelo poder, "pressupõe-se a existência de um sistema legal contra o qual ou em nome do qual os agentes típicos de um relato narrativo militam" (p. 13. Tradução nossa). ${ }^{105} \mathrm{Na}$ verdade, toda a obra de Heródoto mostra-se admiravelmente próxima do pressuposto de White de que "a narrativa, em geral, do conto ao romance, dos anais à

\footnotetext{
105 “(...) presupposes the existence of a legal system against which or on behalf of which the typical agents of a narrative account militate."
} 
'história' plenamente realizada, tem a ver com os temas do direito, da legalidade, legitimidade ou, mais genericamente, da autoridade" (p. 13. Tradução nossa). ${ }^{106}$

Este é, sem dúvida, o caso do lógos de Ciro: a luta pela autoridade entre os medas e os persas, o que pode, mais geralmente, ser ampliado para a luta entre os gregos e os bárbaros. Isso se relaciona fortemente com a discussão de White: Heródoto está expondo aqui o viés político-social em que ele necessariamente produziu seu trabalho. O texto das Histórias, portanto, pode e deve ser analisado como uma obra de história narrativa que apresenta o viés político-social do autor:

Nas Histórias, os esquemas trágicos servem, pois, como modelo de inteligibilidade do poder despótico, permitindo inscrevê-lo na narrativa, dar conta de seu funcionamento, explicar seu fracasso. Trata-se de um meio de que o narrador lança mão para fazer o destinatário crer que tem acesso a esse mundo outro, distanciado no espaço ou no tempo. Mas as Histórias não são nem uma tragédia, nem uma montagem de tragédias. (HARTOG, 1999, p. 338)

106 “(...) narrative in general, from the folktale to the novel, from the annals to the fully realized 'history,' has to do with the topics of Law, legality, legitimacy, or, more generally, authority." 
“A primeira função do discurso histórico 
sempre foi a de divertir, a maior parte das pessoas leem história para espairecer e sonhar".

DUBY, A História Continua

\section{CONCLUSÃO}

A História, entendida como a elaboração de um estudo racional e critico do passado, está longe de ter sido um gênero inventado, criado ou inaugurado por Heródoto. Acreditamos que ele era, sim, um historiador, definindo tal função como a daquele que interroga os eventos passados, com senso crítico sobre suas causas e efeitos, utilizando-se de método e variedade de fontes.

Reconhecemos, porém, que há nas Histórias outros níveis de compreensão e produção de uma obra acerca das Guerras Médicas. Níveis os quais foram, à nossa pesquisa, considerados mais instigantes e consistentes sob o ponto de vista do emaranhado de conhecimentos produzidos no século $\mathrm{V}$ a.C. - história, filosofia, teatro... O que propusemos e ora concluímos é que a natureza da obra herodotiana tem um caráter de descrição e investigação do passado que se dá à sedução e entretenimento do público, ao mesmo tempo em que o faz conhecer e "presenciar" pelos olhos dos historiadores aquilo que não lhes é dado conhecer por seus próprios olhos. Essa característica, então, faz um tipo mensageiro, similar ao mensageiro trágico na função e no discurso.

Como bem o disse Flory (1987, p. 157), não houve nenhum Heródoto antes de Heródoto e nenhum, também, depois dele: sua obra foi única para seu tempo e nunca pode ser repetida. Ele buscou entender o mundo de sua época escrevendo a seu respeito e sugerindo uma nova abordagem que nos faz aceitar seu trabalho em seus próprios termos. É no historiador de Halicarnasso que reconhecemos a ideia de que o real só é dado ao (re)conhecimento pela utilização, comparação e/ou equiparação ao imaginável, ao contrário 
do que distinções mais antigas afirmavam sobre a diferença entre ficção e história, isto é, distinções nas quais a primeira era o lugar da fantasia e a segunda, o lugar do verdadeiro.

Como alguém que pretende apresentar algo novo, Heródoto expressa claramente em seu texto aquilo que traz como marca da diferença: a sua assinatura logo na primeira linha do prólogo da obra, suas declarações de ter feito pesquisas minuciosas, de ter se utilizado do olhar das testemunhas e de que tinha suas próprias reflexões sobre o que descrevia. Ele marca suas intenções e fala de todos. As Histórias são uma obra e, como tal, são fabricadas (pepoihménai) por seu autor. Por isso, podemos afirmar que elas são fruto de certas estratégias narrativas que dramatizam os assuntos abordados.

As obras, sejam elas de história, literatura ou de qualquer outra origem, não têm sentido estável e universal. Por isso, a nosso ver, é importantíssimo admitirmos que a obra herodotiana assumiu posições as mais variadas e foi submetida às mais diferentes análises e críticas de acordo com as necessidades dos tempos e locais ocupados por ela ao longo da história da humanidade. Ela foi investida de significações construídas nas relações entre proposições e sua recepção, e no embate entre os motivos que lhes dão sua estrutura e as expectativas dos públicos que delas se apropriaram. A história das Histórias foi renovada em suas interpretações e redescoberta em seus sentidos, mostrando-se digna de ser atual ao longo dos tempos, por adequar-se ao olhar dos pesquisadores e dos espectadores que têm feito dela uma obra com sentidos em constante construção.

Sua leitura não pode ser enquadrada em uma interpretação pretensamente correta que constranja o olhar do leitor. Portanto, à obra devem ser, constantemente, dadas novas análises relativas à sua forma de expressão, relativas às mais diferentes expectativas, pois a recepção é sempre detentora da capacidade de inventar, deslocar e distorcer o texto. Não diferente de quaisquer outros, os livros de Heródoto foram escritos em condições específicas de tempo e espaço, delimitados por regras, convenções e hierarquias. Mas, como uma grande obra, eles ultrapassaram suas fronteiras, evadiram de sua época e ganharam densidade numa longuíssima duração.

Como razão de tais movimentos está o fato de que, em seu trabalho, Heródoto mostrase maravilhado com o belo expresso nas ações dos homens e é sempre capaz de surpreender, realizando uma narrativa singular acerca dos grandes e dos pequenos, bem como dos fenômenos naturais e sociais que os circundam, buscando compreender e tornar compreensível aquilo antes sem explicação. Percebemos que o que o autor buscava era uma descrição completa e a mais fiel possível, em suas diferentes manifestações e versões. Por isso, seu papel era antes o de observador: observava para narrar. 
Parece-nos inegável que houve um método estabelecido pelo historiador de Halicarnasso, pois ele examinou os "documentos", fez medições, distinguiu entre versões, concebeu o que havia de mais plausível nelas, transcreveu-nos suas próprias reflexões, compôs uma narrativa, traçou o objetivo de narrar uma guerra e nos deu detalhes para que formássemos quadros acerca das histórias de que tratava. As imagens foram, portanto, formadas em nossas mentes e os personagens e fatos ganharam vida, tornando-se objeto de conhecimento.

Ressaltamos que, em seu século, nenhuma outra obra foi resultado de pesquisas tão amplas e variadas. Em nome de não deixar cair no esquecimento os grandes feitos daqueles que eram grandes e dos que já o haviam sido, escolhas foram feitas, histórias foram conservadas e novos olhares gregos foram lançados sobre tudo aquilo que não escapou ao olhar do pesquisador. Alicerçando-nos em Hartog, afirmamos que as Histórias instauraram a estrutura profunda da narrativa histórica (1999, p. 28).

A habilidade narrativa de Heródoto é notável. A despeito da enorme heterogeneidade do material que reuniu, não perdeu o fio condutor: as digressões, compostas de mitos, anedotas, curiosidades etnológicas e geográficas, são bem marcadas e foram magistralmente dispostas em torno da narração principal. Como um gênero que começava a surgir, a História encontrou nas Histórias forte contribuição no sentido de que a obra carrega em si elementos combinados em múltiplas dimensões e finalidades.

Uma das situações que mais encantam e fascinam é a percepção de que as diferentes versões dialogam umas com as outras e, mesmo quando nos falta exatidão quanto à cronologia, as personagens e os espaços dos fatos, somos levados a admitir que as narrativas compõem um texto único em sentido. Sem perder de vista as personagens que fazem parte da narrativa e mesmo dando relevo a elas, o mundo narrado, isto é, o fato escolhido para a obra as Guerras Médicas - está a todo o momento sob o foco de atenção.

Bem, Heródoto cria, na verdade, histórias próprias. Suas versões fazem parte de um importante cenário construído paulatinamente ao longo dos livros e deles fazem parte o maravilhoso, o fantástico, o espetacular. Como historiador, Heródoto elegeu, selecionou, deu prioridade a alguns, sintetizou o relato sobre outros; suas opções e valorações seguiram sua intenção não de ser exaustivo, mas de responder aos anseios de conhecimentos dos gregos de seu tempo. Como literato, manteve-se ligado às expectativas do leitor de experimentar o prazer da leitura e de receber uma narrativa recheada de dados visuais, sensoriais e emocionais que tornam o narrado mais próximo. 
$\mathrm{Na}$ mistura do historiador com o literato encontramos o artista e a figura que transmite mensagens de fora se faz crer por ter visto aquilo que ninguém mais presenciou ou poderia presenciar e que, por isso mesmo, ganhava créditos de verdadeiro: um mensageiro. Ao narrar com estratégias dramáticas e mesmo alguma teatralidade dos gestos e atos, encontramos o mensageiro trágico. Era possível a Heródoto dar notícia do extraordinário, utilizando-se de toda a sua curiosidade e gostos pessoais, ao criar aquilo que transmitia, e suas mensagens engendravam o prazer pela leitura de um texto carregado de questionamentos sobre as práticas, desejos e necessidades do outro.

$\mathrm{Na}$ verdade, nada daquilo que foi escrito, transcrito ou transcriado nas Histórias era dado à conferência exata e imediata das e nas fontes, embora estas existissem e fossem citadas como testemunhas dos eventos narrados, ou seja, elas eram implícitas e, assim, era como se lá estivessem. Não havia aqueles que aparecessem para negar e tudo era, por mais incrível, sempre plausível porque sempre muito verossímil. Por que não narrar, então, o qauma \&s iov encontrado nas realidades observadas? O mundo apreendido e deduzido dos próprios princípios possibilitava a narração de uma sorte de situações fantásticas alimentadas pela vontade de saber e dadas ao conhecimento e ao convencimento.

Heródoto oscila em sua narrativa entre a história que se utiliza da ficção e a ficção que se quer representar como história. Nesse sentido, a introdução de elementos que fazem parte do yeu $=$ dov está ligada às necessidades do projeto narrativo. $\mathrm{O}$ que de mais importante devemos admitir, aqui, a este respeito, é que a esfera na qual as Histórias estão inseridas é sem dúvida a da História e que, embora a ficção não seja a sua marca maior, o efeito principal delas é o prazer da narrativa.

Nesse contexto, as técnicas de dramatização ilustram bem como o plano real empírico pode ser (re)contado através do que há de mais original na tradição de uma sociedade, representado, aqui, para nós, no teatro. Sem dúvida, o teatro, e tudo aquilo que ele engloba, é uma das características mais marcantes do que foi produzido na Grécia no século V a.C. e é firme legado daquele povo aos homens de diferentes culturas ao passar dos séculos.

Como afirma Jacyntho Brandão (2001, p. 204-205), o teatro florescente no quinto século a.C. participa da grande crise que marca a vida grega do período, permitindo que possamos defini-lo como um gênero próprio da crise. Entendendo crise em seu próprio sentido grego, isto é, o de kri\&siv enquanto processo judicial, com suas partes, tais quais a faculdade de discernir e a sentença, tanto quanto o agw\&n, ou seja, o embate inerente ao processo, característica tão marcante na tragédia, afirmamos que o período por nós destacado 
colocava em discussão, através do olhar e da comparação com o outro, o diferente, tudo aquilo que herdara culturalmente. Heródoto é para nós, então, claramente, um homem não à frente de seu tempo, mas próprio de seu tempo, ao deixar explicita em sua obra a kri\&siv de sua época, não só por aquilo que narra, mas pela forma como narra com percepção e discernimento sobre o diferente e o grego e por adotar o papel de um narrador que assume o momento crítico da recepção da narrativa pelo público como momento de embate no qual seu discurso deveria permanecer e prevalecer a todo custo.

Sem dúvida, o teatro, em especial a tragédia, supõe esse processo. Há uma perspectiva da diferença que se fixa às partes opostas do litígio e que, através da forma narrativa, da variedade de versões e do encantamento da recepção, se torna capaz de dar um desenlace às situações morais, éticas, religiosas, enfim, toda sorte das produções da cultura de um povo. Nesse contexto, a personagem do mensageiro tem papel fundamental no enredo de uma peça teatral, pois é através de sua voz que vêm as notícias sobre o diferente, que vêm as mensagens sobre o olhar daquele que pode presenciar o outro e por isso é capaz de levar ao desenlace, ao juízo, à sentença toda a trama da história encenada sob os olhos das personagens e sob os olhos do público:

\begin{abstract}
O teatro, de fato, configura um espaço para o exercício da visão da diferença: o público que contempla o espetáculo, justamente porque enquadrado na categoria dos theataí, tem sempre lembrada a distância que separa a cena da plateia e, consequentemente, a distância entre o que se representa e a vida, de tal modo que, no teatro, prevalecem outros critérios de virtude e maestria: "quem consegue iludir é mais justo do que quem não o consegue e quem se deixa iludir mais sábio do que quem não se deixa iludir", para usar a fórmula de Górgias. (...) A própria estrutura física do théatron leva a que não se possa defender a prevalência de um único ponto de vista, isto é, não existe ângulo correto para ver-se sem distorção, o que tem como consequência que todos os ângulos são legítimos, porque todos, em princípio, são deslocados. Se da perspectiva tanto da produção do texto, quanto do espetáculo podem-se distinguir graus diversos de propriedade, do ponto de vista da recepção o teatro supõe, em virtude de sua própria forma, a diferença como norma. (...) Esse é o dado essencial a reter: a opção teatral tem como função fornecer ao narrador um ângulo deslocado, contaminar o estatuto do produtor do discurso com o imprevisto da visão dos recebedores. (BRANDÃO, 2001, p. 205-207)
\end{abstract}

A contemplação como espectador, consciente da distância que separa a cena da plateia, é o dado relevante, para nossa argumentação final. Pois, de forma semelhante à do teatro, as histórias narradas pelo Heródoto mensageiro faz com que o seu espectador possa ver a si mesmo nas palavras das Histórias, porém, de forma desfocada. Utilizando-se da perspectiva teatral na criação de sua narrativa, nosso historiador problematiza o igual - o grego - e contempla o familiar - o quase-grego - como estranho - o não-grego. 
É necessário que, ao fim, levantemos ainda uma última questão: o que diferenciaria, então, a narrativa literária da narrativa histórica? O que faz com que, apesar de toda a literariedade, as Histórias sejam uma obra de história e não de ficção? Como argumentamos de diversas maneiras ao longo de nosso trabalho, a literatura trata do universal, organiza-se por regras de verossimilhança em relação ao que poderia acontecer, representa uma ação inteira no tempo e espaço e tem como objetivo o prazer próprio a ela. Já a História é o conhecimento do particular que, embora vise ao prazer em sua narrativa, não faz dele característica própria e, embora obedeça a critérios de verossimilhança, é a narrativa de ações que de fato ocorreram em um tempo e um espaço, mas que mantêm com o passado e com o futuro relações de causalidade. Mas, mais que esses critérios, está o primeiro contato com o leitor, que infere dos conteúdos e formas gráficas de apresentação da obra o objetivo final de sua leitura, isto é, se se trata de uma obra histórica ou de ficção.

Contudo, é fundamental que admitamos, como nos advertiu Brandão (2005b, p. 165), que a historiografia, em maior ou menor grau, sempre admitiu o fictício, entendido como a reconstrução do historiador balizada por uma verdade externa e constituída como mimese desta. É assim que admitimos ser Heródoto aquele que escreve a história não segundo a objetividade máxima, mas, sim, imbuído de um espírito mimético de fortes semelhanças com o gênero trágico.

Portanto, acreditamos profundamente que as Histórias são uma obra que aborda os grandes conflitos de seu tempo, mostrando a grande diversidade cultural dos povos e refletindo sobre tudo aquilo que era humano, inclusive a participação dos deuses nesse humano. $\mathrm{O}$ alcance das informações é imenso e as opções do autor perpassam vários temas, objetos, personagens e formas de narrar. Já passamos do tempo de prefigurarmos a obra herodotiana como um ajuntado de histórias inventadas ou como uma obra de história ainda não definida como tal, por ser a primeira e ainda se encontrar em um tempo no qual a i 9stori\&a ainda não se definira como a história que concebemos na contemporaneidade.

Concluímos que nosso historiador é uma combinação de historiador e literato, não sendo exatamente nem um, nem o outro. Ele não emprega todos os aparatos de um dramaturgo, mas suas histórias repassam pedaços das observações pessoais sobre as histórias populares, com técnicas de dramatização. Heródoto é a imagem da transição entre os elementos de uma realidade desordenada e a certeza artística de uma lei universal. Compartilhando dos sentimentos, angústias e tendências dos homens da época em que viveu, ele se singularizou, imortalizou a sua obra e lhe conferiu um cunho de atualidade graças à percepção multicultural de que reveste seu discurso. 
As mensagens transmitidas por nosso narrador/historiador/personagem comunicam-se com as pessoas como um todo: não apenas com os pensamentos e a razão, mas com as emoções, paixões e (pré)conceitos. Ele desafiava os gregos e nos desafia, enquanto leitores espectadores e cientistas ou acadêmicos, a encararmos aspectos das nossas vidas e das nossas pesquisas que tentamos ignorar. Ele é, ainda, uma forma divertida de compartilhar informações, realizar reflexões e produzir e passar adiante conhecimento.

É no historiador de Halicarnasso que percebemos claramente a tendência de conjugar a produção de um conhecimento objetivo acerca de relações acessíveis para o homem em relação à sua posteridade e a representação dessas mesmas relações em um universo de encantamento como o teatro. É da tragédia que Heródoto herda, sem dúvida, o modo de pensar e o estilo. A antiga tradição que afirma a amizade de Heródoto com Sófocles poderia, sem problema algum, ser demonstrada na marca trágica que envolve muitos dos nove livros das Histórias, como, aliás, seria de se esperar, sendo a tragédia um gênero próspero no século $\mathrm{V}$.

A tragédia exerce, de fato, grande influência sobre a estrutura narrativa e ao conteúdo temático das Histórias. A tendência de representar os fatos pela encenação de personagens em ação é o elemento fundamental da tragédia e é, também, elemento fundamental em Heródoto. Por mais histórica que fosse, a narrativa herodotiana estava plena de gestos e expressões que a aproximavam da tragédia - e por isso chamamos Heródoto de mensageiro, pela proximidade que há entre sua forma de narrar e a desta personagem da tragédia, bem como pela proximidade que há, nas suas Histórias, entre fato e ficção, ou melhor, pelo modo como, nelas, se quebram as barreiras entre essas duas esferas da realidade. 


\section{REFERÊNCIAS}

ABEL, Lionel. Metateatro - uma visão nova da forma dramática. Rio de Janeiro: Zahar, 1968.

ADLER, Stella. Técnica da representação teatral. Rio de Janeiro: Civilização Brasileira, 2008.

ARISTOTELE. Poetica. Introduzione, traduzione e note di Diego Lanza. Milano: Biblioteca Universale Rizzoli, 1992.

ARISTÓTELES. A ética. Tradução de Cássio M. Fonseca. Rio de Janeiro: Tecnoprint Gráfica, 1971.

. Arte Retórica e Arte Poética. Tradução Antônio Pinto de Carvalho. São Paulo: Difusão Européia do Livro, 1959.

Ética a Nicômaco. Tradução de Pietro Nasseti. São Paulo: Martin Claret, 2007.

ARISTOTLE. Metaphysica. Translated by W. D. Ross, M. A. e Hon. LL. D. London, Oxford University Press, 1966.

2005 .

Poetics. Translated by Stephen Halliwell. London: Harvard University Press, Press, 1998.

The Nicomachean Ethics. Translated by David Ross. Oxford: Oxford University 
ARISTÓFANES. As Nuvens. Tradução de Jaime Bruna. São Paulo: Cultrix, 1964.

ARNDT, Willian; GINGRICH, F. Wilbur \& BAUER, WALTER. Greek-English lexicon of the New Testament: and other early christian literature. Chicago: University of Chicago, 1957.

ASHERI, David; LLOYD, Alan; CORCELLA, Aldo. A commentary on Herodotus books I-IV. USA: Oxford University Press, 2007.

AZEVEDO, Flávia Lemos Mota de. A pólis e o maravilhoso na narrativa de Heródoto. Revista Archai, Brasília, n. 01, p. 33-41, Jul 2008. Disponível em http://archai.unb.br/revista. Acesso em 28 de maio de 2009.

BAKHTIN, M. Problemas da poética de Dostoievski. Rio de Janeiro: Ed. ForenseUniversitária, 1981.

BARRETT, James. Staged narrative: poetics and the Messenger in Greek tragedy. Los Angeles: University of Californis Press, 2002.

BARROS, D. L. P.; FIORIN, J. L. Dialogismo, polifonia e intertextualidade. São Paulo: Editora da Universidade de São Paulo, 2003.

BEBIANO, Rui. Sobre a História como poética. Disponível em http://ruibebiano.net/docs/hpoetica.pdf. Acesso em 01 de novembro de 2009.

BENJAMIM, Walter. O narrador. Oras escolhidas. Magia e técnica, arte e política. São Paulo: Brasiliense, 1996.

BLANCO, Walter; ROBERTS, Jennifer Tolberts (Ed.). Herodotus: The Histories: new translation, selections, backgrounds, commentaries. London/New York: W. W. Norton \& Company, 1992.

BLOCH, Marc. Apologia da História, ou, o ofício de historiador. Rio de Janeiro: Jorge Zahar, 2001.

BRANDÃO, Jacyntho José Lins. A antiga musa: (arqueologia da ficção). Belo Horizonte: Faculdade de Letras da UFMG, 2005a.

A invenção do romance. Brasília: Editora Universidade de Brasília, 2005 b.

A poética do hipocentauro: literatura, sociedade e discurso ficcional em Luciano de Samósata. Belo Horizonte: Ed. UFMG, 2001.

BRANDÃO, Junito de Souza. Teatro Grego: tragédia e comédia. Petrópolis: Vozes, 1985.

BROWN, Truesdell S. Herodotus and his profession. The American Historical Review, $\mathrm{n}^{\circ} 4$, v. 59, julho de 1954. Disponível em http://www.jstor.org/stable/1845119. Acesso em 01 de novembro de 2009. 
BURGUIÈRE, André. Dicionário das Ciências Históricas. Rio de Janeiro: Imago, 1993.

BURROW, John. A history of Histories: epics, chronicles, romances and inquiries from Herodotus and Thucydides to the twentieth century . UK: Knopf, 2008.

CABRAL, João de Pina. Semelhança e verossimilhança: horizontes da narrativa etnográfica. Mana, v. 09, $\mathrm{n}^{\mathrm{o}}$ 01. Rio de Janeiro, abril de 2003. Disponível em http://www.scielo.br/scielo. Acesso em 30 de julho de 2009.

CALAME, Claude. Mythe et histoire dans l'antiquité grecque. Lausanne: Editions Payot Lausanne, 1996.

CANDIDO, Antônio et al. A personagem de ficção. São Paulo: Editora Perspectiva, 1976.

CASSIRER, Ernst. Linguagem e Mito. São Paulo: Perspectiva, 1972.

CERTEAU, Michel de. A escrita da História. Rio de Janeiro: Forense-Universitária, 1982.

CHAMBERLAIN, David. On atomics onomastic and metarrythmic translations in Herodotus. Arethusa, $\mathrm{n}^{0}$ 32. Baltimore: The Johns Hopkins University Press, 1999.

CHARTIER, Roger. A História hoje: dúvidas, desafios, propostas. Estudos Históricos, vol. 7, n. 13. Rio de Janeiro: [s.e.], 1994.

CÍCERO. De Oratore. Translation by Harry Caplan. London: Harvard University Press, [s.d.].

COLLINGWOOD, R.G. A ideia de história. Lisboa: Editorial Presença, 1986.

DEMETRIUS. On style. London: Harvard University Press, 2007.

DETIENNE, Marcel. A invenção da Mitologia. Rio de Janeiro: José Olympio, 1988.

DICKING, Margaret. A vehicle for performance - acting the messenger in Greek tragedy. Lanham: University Press of America, 2009.

DILLERY, John. Reconfiguring the past: Thyrea, Thermopylae and narrative patterns in Herodotus. American journal of Philology, $\mathrm{n}^{\circ}$ 117. Baltimore: The Johns Hopkins University Press, 1996.

DUBY, Georges. A História continua. Rio de Janeiro: Jorge Zahar, 1993.

ECO, Umberto. Tratado geral de Semiótica. São Paulo: Editora Perspectiva, 2003.

ELIADE, Mircea. Mito e realidade. São Paulo: Perspectiva: 2000.

ÉSQUILO. Os Persas. Tradução de Maria José de Carvalho. Disponível em http://www.scribd.com/doc/6581266/Esquilo-Os-Persas. Acesso em 17 de janeiro de 2010. . Prometeu Acorrentado. Tradução de Jaime Bruna. São Paulo: Cultrix, 1964. 
ERODOTO. Le Storie. Construzione, versione interlineare, argomenti e note di Scarpa Giancarlo. Milano: Edizione Avia Pervia, 1998.

EURIPIDES. As Fenícias. Tradução de Donaldo Schüler. Porto Alegre: L\&PM, 2008.

Bacchanals; Madness of Hercules; Children of Hercules; Phoenician Maidens; Suppliants. With an English translations by Arthur S. Way. London: Havard University Press, 1950.

Electra; Alceste; Hipólito. Tradução do grego, prefácio e notas de J. B. Melo e Souza. Rio de Janeiro: Ediouro, 1986.

Electra; Orestes; Iphigeneia in Taurica; Andromache; Cyclops. With an English translations by Arthur S. Way. London: Havard University Press, 1958.

Fabulae. Recognovit, latine vertit, in duodecim fabulas annotationem criticam scripsit, omnium ordinem chronologicum indagavit Theobaldus Fix. Paris: Editore Ambrosio Firmin-Didot, 1878.

Hipólito. Tradução de Jaime Bruna. São Paulo: Cultrix, 1964.

Ifigênia em Áulis; As Fenícias; As Bacantes. Tradução do grego, apresentação e notas Mário da Gama Kury. Rio de Janeiro, Jorge Zahar Editor, 2005.

. Medéia. Tradução do grego de Jaa Torrano. São Paulo: Hucitec, 1991.

2004.

Medéia. Tradução de Millôr Fernandes. Rio de Janeiro: Civilização Brasileira,

Os Heraclidas. Introdução e versão do grego de Cláudia Raquel Cravo da Silva. Madrid: Ediciones Clásicas Madrid, 2001.

FELDMAN, Allen. Memory theaters, virtual witnessing, and the trauma-aesthetic. Biography, winter, 2004.

FLORY, Stewart. The archaic smile of Herodotus. Detroit: Wayne State University Press, 1987.

FREITAS, Marcus Vinicius de. A Função do Testemunho no Discurso Historiográfico de Heródoto. In: LOPES, A. O. D.; LAGE, C. F. \& FLORES Jr., O. (org). Scripta Classica: História, Literatura e Filosofia na Antigüidade Clássica. Belo Horizonte: Ed. Do Autor, 1999.

GIAGIULIO, Maurizio. (a cura). Erodoto e il "modelo erodoteo": formazione e tramissione delle tradizioni storiche in Grecia. Trento: Università degli Studi de Trento, 2005.

GRIFFITHS, Alan. Behind the lines: the genesis of stories in Herodotus. In: BUDELMANN, F; MICHELAKIS, P. Homer, tragedy and beyond: essays in honour of P. E. Easterling, London, 2001.

GOULD, John. Herodotus. Cambridge: Duckworth Publishers, 2002. 
GREENE, David. The Historian as Dramatist. The journal of Philosophy, v. 58, $\mathrm{n}^{\mathrm{o}}$ 18. [s.c]: [s.e.], 1961.

GREGORIO, Lamberto. Le scene d'annuncio nella tragedia greca. Milano: Società Editrice Vita e Pensiero, 1967.

GROSSI, Y. S.; FERREIRA, A. C. Razão Narrativa: Significado e Memória. História Oral, São Paulo, n. 04, junho 2001.

GUARINELLO, Norberto. Breve Arqueologia da História Oral. História Oral, São Paulo, n. 01, junho 1998.

HAMILTON, Edith. O eco grego. São Paulo: Landy Editora, 2001.

HARTOG, François (Org). A História de Homero a Santo Agostinho. Belo Horizonte: UFMG, 2001.

Memória de Ulisses: narrativas sobre a fronteira na Grécia Antiga. Belo Horizonte: Ed. UFMG, 2004.

UFMG, 1999.

O espelho de Heródoto. Ensaio Sobre a Representação do Outro. Belo Horizonte: 2003.

Os antigos, o passado e o presente. Guimarães, José Otávio (org.). Brasília: UnB,

HAYES, Wayne R; HARTOG, François. Herodotus and the Historiographical Operation. Diacritics, v. 22, nº 2. [s.c], The Johns Hopkins University Press, 1992.

HERODOTE. Histoires. Text etabli et traduit par Ph. E. Legrand. Paris: Les Belles Lettres, 1939-1954.

HERÓDOTO. História. Tradução J. Brito Broca. São Paulo: Ediouro, 2001.

Histórias. Livros I, III, IV, V, VI, VIII. Lisboa: Edições 70, 2000.

HERODOTUS. Histories. Translation by A. D. Godley. Cambridge/Massachusetts: Harvard University Press, 1996.

The Histories of Herodotus. Translation by G. C. Macauley. Disponível em http://www.sacred-texts.com/cla/hh/index.htm\#section_001. Acesso em 08 de dezembro de 2009.

HESÍODO. Teogonia. Tradução de Jaa Torrano. São Paulo: Iluminuras, 2001.

HOLLMANN, Alexander. The manipulation of signs in Herodotos' Histories. Transactions of the American Philological Association. 2005.

HOMERO. Odisséia. Tradução de Frederico Lourenço. Coimbra: Livros Cotovia, 2003. 
IMMERWAHR, H. R. Form and thought in Herodotus. Atlanta: Scholars Press, 1966.

JAEGER, Werner. Paidéia: a formação do homem grego. São Paulo: Martins Fontes, 1995.

JAKOBSON, Roman. Língua, discurso, sociedade. São Paulo: Global Ed, 1983.

JOHNSON, W. A. Oral Performance and the Composition for Herodotus "Histories". Greek, Roman and Byzantine Studies, v. 35, 1994.

JOLLES, A. Formas simples. São Paulo: Cultrix, 1976.

JONG, Irene J. F. de. Narrative in drama: the art of the Euripidean messenger-speech. Netherlands: [s.e.], 1991.

KITTO, H. D. F. A tragédia grega. Coimbra: Armênio Amado, 1972.

LIDELL, Henry George \& SCOTT, Robert. A Greek-English lexicon. Oxford: Clarendon Press, 1996.

LATEINER, Donald. Nonverbal Communication in the Histories of Herodotus. In: Arethusa, New York, v. 20, n. 1/2, 1987.

- Signifying names and other ominous accidental utterences in classical historiography. Greek, Roman and Byzantine Studies, 2005.

1989.

The historical method of Herodotus. Toronto: University of Toronto Press,

LE GOFF, Jacques. História e memória. São Paulo: Editora da UNICAMP, 2003.

LE GOFF, Jacques \& NORA, Pierre. História: novos problemas. Rio de Janeiro: Francisco Alves, 1976.

LESKI, Albin. A tragédia grega. São Paulo: Perspectiva, 2006.

LÉVÊQUE, Pierre. A aventura grega. Rio de Janeiro: Cosmos, 1967.

LONGINO. Do Sublime. Tradução de Filomena Hirata. São Paulo: Martins Fontes, 1996.

LONGINUS. On the sublime. London: Havard University Press, 2007.

LORAUX, Nicole. Elogio do Anacronismo. In: Tempo e História. São Paulo: Companhia da Letras, 2002.

LUCIANO. Como se deve escrever a História. Tradução e Ensaio de Jacyntho Lins Brandão. Belo Horizonte: Tessitura, 2009. Gredos, 1990.

Obras. Traducción y notas por Juan Zaragoza Botella. Madrid: Biblioteca Clásica 
MARINCOLA, John. Herodotean Narrative and the Narrator's Presence. Arethusa, New York, v. 20, $\mathrm{n}^{\mathrm{o}} 1 / 2,1987$.

MARROU, H. I. Do conhecimento histórico. Lisboa: Áster, [s.d.].

McMAHON, Darrin M. Felicidade uma história. Disponível em http://globolivros.globo.com/downloads/pdf/Pages_from_felicidade_miolo_final_3.pdf. Acesso em 22 de julho de 2009.

MÉNARD, René. Mitologia greco-romana. São Paulo: Opus, 1991.

MERLEAU-PONTY, M. O visível e o invisível. São Paulo: Perspectiva, 2003.

MONTIGLIO, Silvia. Wandering in Ancient Greek culture. Chicago: University of Chicago, 2005.

MORAIS, Cynthia. Maravilhas do mundo antigo: Heródoto Pai da História?. Belo Horizonte: Ed. UFMG, 2004.

MORELO, Sonila. A relativização da verdade em Heródoto. 2000. Dissertação (Mestrado em História) - Universidade Federal de Minas Gerais, Belo Horizonte.

MYRES, John L. Herodotus father of History. Oxford: Clarendon, 1952.

NIETZSCHE, Friedrich Wilhelm. O nascimento da tragédia, ou, Grécia e pessimismo. São Paulo: Escala, 2007.

NOVAES, A. (org.). Tempo e História. São Paulo: Companhia da Letras, 2002.

ONG, Walter. Oralidade e cultura escrita. Campinas: Papirus, 1998.

PASSERINE, S. P. O fio de Ariadne. Um Caminho para a Narração de Histórias. São Paulo: Ed. Antroposófica, 1998.

PAYEN, Pascal. Les ilês nômades. Conquérir et résister Dan l'enquête Hérodote. Paris: Éditions de l'École des Hautes Études em Sciences Sociales, 1997.

PESTANA, Álvaro César. História e ficção em Heródoto. Disponível em alvarocpestana.googlepages.com/HERODOTO.pdf. Acesso em 22 de julho de 2009.

PLATÃO. A República. Tradução de Carlos Alberto Nunes. Belém: UFPA, 1988.

PLAZA, Julio. Tradução Intersemiótica. São Paulo: Editora Perspectiva, 2001.

POWELL, J. Enoch. A lexicon to Herodotus. Cambridge: Cambridge University Press, 1966.

The History of Herodotus. Cambridge: University Press, 1939. 
RICCEUR, Paul. A memória, a história, o esquecimento. Campinas: Editora UNICAMP, 2007.

RIBEIRO, Tatiana Oliveira. 101boj: uma discussão axiológica nas Histórias de Heródoto. 2005. Dissertação (Mestrado em Letras Clássicas) - Universidade Federal do Rio de Janeiro, Rio de Janeiro.

RICHARD, Nelly. Intervenções críticas. Belo Horizonte: UFMG, 2002.

RODRIGUES, Rodrigo de Melo Falcão. Heródoto e as musas, ou, Clio irmã de Calíope. 2000. Dissertação (Mestrado em História), Universidade de Brasília.

ROJO, S. \& VECCHI, R. (org.) Transliterando o real. Belo Horizonte: Faculdade de Letras, 2004.

ROMERO, Jose Luis. De Herodoto a Polibio: El pensamiento histórico em la cultura griega. Buenos Aires: Espasa-Calpe, 1952.

ROSENFELD, Anatol. O teatro épico. São Paulo: Perspectiva, 1985.

RIBEIRO, Tatiana Oliveira. 101boj: uma discussão axiológica nas Histórias de Heródoto. 2005. Dissertação (Mestrado em Letras Clássicas) - Universidade Federal do Rio de Janeiro, Rio de Janeiro.

SALVADOR, Evandro Luis. Os Sete Contra Tebas de Ésquilo: introdução tradução e comentários. 2006. Dissertação (Mestrado em Linguística) - Universidade de Campinas, Campinas.

SANCHO-MONTÉS, Susana. Procedimentos de dramatización en las Historias de Heródoto (libros I-IX). Amsterdam: Hakkert, 2003.

SCHMIDT, Joël. Dicionário de Mitologia Grega e Romana. Lisboa: Edições 70, 1985.

SERRA, Ordep José Trindade. A Antropologia, a Mitologia e a sua escrita. Classica, São Paulo, v. 11/12, 1998/1999.

SHAMPIRO, Susan O. Proverbial wisdom in Herodotus. Transactions of the American Philological Association, [s.c.], n. 130, 2000.

SILVA, Gustavo Adolfo. Teoria dos Atos de Fala. Disponível em http://www.filologia.org.br/viiifelin/41.htm. Acesso em 19 de julho de 2009.

SOARES, Carmen Isabel Leal. A morte em Heródoto - valores universais e particulares étnicos. Coimbra: Fundação Calouste Gulbenkian, 2003.

SÓFOCLES. Édipo em Colono. Tradução de Donaldo Schüler. Porto Alegre: L\&PM, 2007. Édipo rei. Tradução de Jaime Bruna. São Paulo: Cultrix, 1964. Édipo rei. Tradução Trajano Vieira. São Paulo: Perspectiva, 2007. 
Filoctetes. Tradução de Trajano Vieira. São Paulo: Editora 34, 2009.

SOPHOCLE. Antigone. Notice et notes Ch. Georgin. Paris: Librarie A. Hatier, 1986.

STRASSLER, Robert B. (Ed.). The landmark Herodotus: The Histories. Translator. Andrea L. Purvis. Boston: Pantheon, 2007.

SUTERMEISTER, Paul. A meta-história de Hayden White: uma crítica construtiva à "ciência" histórica. Revista Espaço Acadêmico, no 97, v. 9, junho de 2009. Disponível em http://periodicos.uem.br/ojs/index.php/EspacoAcademico/index. Acesso em 01 de novembro de 2009.

THOMAS, Rosalind. Herodotus in context - ethnography, science and the art or persuasion. Cambridge: Cambridge University Press, 2000.

. Letramento e oralidade na Grécia Antiga. São Paulo: Odysseus Editora, 2005.

THOMPSON, Paul. A voz do passado. História Oral. Rio de Janeiro: Paz e Terra, 1992.

THULEEN, Nancy. The historical narrativity of Herodotus. Disponível em http://www.nthuleen.com/papers/L10herodotus.html. Acesso em 27 de agosto de 2009.

TODOROV, Tzvetan. As estruturas narrativas. São Paulo: Perspectiva, 2003.

Introdução à literatura fantástica. São Paulo: Perspectiva, 2003.

UNERSTEINER, M. La língua di Erodoto. Bari: Adriatica Editrice, 1948.

VASCONCELOS, Helena. Procedimentos estilísticos no discurso do Mensageiro na Fedra de Sêneca. Ágora. Estudos Clássicos em Debate, $\mathrm{n}^{\circ}$ 10. Aveiro: Universidade de Aveiro, 25008.

VIDAL-NAQUET, Pierre. Os assassinos da memória. Campinas: Papirus, 1988.

Os gregos, os historiadores, a democracia: o grande desvio. São Paulo: Companhia das Letras, 2002.

VIEGAS, Anna Maria. Da Metáfora ao Mito. In: MARQUES, M. P.; BARRETO, M. H.; VIEGAS, S. \& VIEGAS, A. M. Mito. Belo Horizonte: Núcleo de Estudos Sônia Viegas, 1994.

WALTERS, K. H. Herodoto El historiador: sus problemas, métodos y originalidad. Mexico: Fondo de Cultura Economica, 1990.

WHITE, H. Meta-história: a imaginação histórica do século XIX. São Paulo: Editora da Universidade se São Paulo, 1992.

The content of the form - narrative discourse and historical representation. Baltimore/London: The Johns Hopkins University Press, 1987. 
Trópicos do discurso - ensaios sobre a crítica da cultura. São Paulo: Edusp, 1994.

WILSON, Norman J. History in crisis?: recent directions in historiography. Upper Saddle River NJ. USA: Prentice-Hall, 1999. 